\begin{abstract}
UNIVERSIDADE DE SÃO PAULO
FACULDADE DE FILOSOFIA, LETRAS E CIÊNCIAS HUMANAS DEPARTAMENTO DE LETRAS ORIENTAIS

PROGRAMA DE PÓS-GRADUAÇÃO EM LITERATURA E CULTURA RUSSA
\end{abstract}

\author{
PAOLA FERNANDES ZAMBONI
}

\title{
Mascarada, Uma Jornada Fascinante da Peça de Liérmontov Aos Palcos De Meyerhold
}

Versão corrigida

SÃO PAULO

2013 


\author{
UNIVERSIDADE DE SÃO PAULO \\ FACULDADE DE FILOSOFIA, LETRAS E CIÊNCIAS HUMANAS \\ DEPARTAMENTO DE LETRAS ORIENTAIS \\ PROGRAMA DE PÓS-GRADUAÇÃO EM LITERATURA E CULTURA \\ RUSSA
}

\title{
Mascarada, Uma Jornada Fascinante da Peça de \\ Liérmontov Aos Palcos De Meyerhold
}

\author{
Paola Fernades Zamboni \\ Dissertação em versão corrigida apresentada ao \\ programa de pós-graduação em Literatura e \\ Cultura Russa do Departamento de Letras \\ Orientais da Faculdade de Filosofia, Letras e \\ Ciências Humanas da Universidade de São Paulo \\ como requisito para a obtenção do título de Mestre \\ em Literatura e Cultura Russa. Pesquisa \\ desenvolvida com o apoio da Coordenação de \\ Aperfeiçoamento de Pessoal de Nível Superior \\ (CAPES)
}

De acordo,

Orientadora: Prof. Dra. Elena Vássina

São Paulo

2013 
Autorizo a reprodução total ou parcial deste trabalho, por qualquer meio convencional ou eletrônico, para fins de estudo ou pesquisa, desde de que citada a fonte. 


\section{AGRADECIMENTOS}

À Coordenação de Aperfeiçoamento Pessoal de Nível Superior (CAPES) pela viabilização da pesquisa.

À Prof. Dra. Elena Vássina, pelo apoio e orientação, pelo carinho e generosidade com que compartilha seus conhecimentos sobre e paixão pelo teatro e literatura russa.

Ao Dr. Vadim Scherbakov, professor do curso de Pós-graduação do Centro Internacional Meyerhold e pesquisadores da Comissão Internacional da Herança Artística de Meyerhold pela valiosíssima troca de ideias e informações que tivemos em sua visita ao Brasil por ocasião do Colóquio Internacional de Teatro Russo em 2008.

Aos Profs. Drs. Mário Francisco Junior e Neide Jallageas pelas valiosas contribuições quando do exame de qualificação.

Aos pacientes e generosos funcionários do Departamento de Letras Orientais, sempre prontos a nos orientar e guiar entre tantos trâmites legais.

Aos professores visitantes e efetivos do curso de Russo com quem tanto aprendi.

À minha querida mãe que infelizmente não chegou a ver o fim desta jornada.

À toda a minha família que me deu suporte nos momentos difíceis e a meu eterno amigo, marido e companheiro que me aguentou e apoiou durante por todo o caminho. 
ZAMBONI, Paola Fernandes. Mascarada, Uma Jornada Fascinante da Peça de Liérmontov Aos Palcos De Meyerhold. São Paulo, 2013. Dissertação (Mestrado em Literatura e Cultura Russa) - Faculdade de Filosofia, Letras e Ciências Humanas, Universidade de São Paulo.

\section{Resumo:}

Mikhail Yurevitch Liermontov (1814-1841) viveu em período marcado por grande comoção social, uma época de transição na vida e na sociedade Russa. Foi nesse contexto que Liérmontov escreveu a peça Mascarada, uma crítica à sociedade e aos hábitos fúteis e mesquinhos de sua época. Vsévolod Emilevitch Meyerhold (18741940) estreou a sua Mascarada em 25 de fevereiro de 1917 em meio a revolução que viria a derrubar a monarquia e a velha Rússia. Depois quase seis anos e ensaios e preparações, figurinos, objetos de cena e cenários criados especialmente para a peça estavam prontos para o que viria ser ao mesmo tempo o fim de uma era e o nascimento de um novo teatro. A presente dissertação se propõe a analisar Mascarada desde a sua gênese no romantismo de Liérmontov até a espetacular montagem de 1917 e seus desdobramentos no teatro.

Palavras-chave: Mikhail Liérmontov, Vsévolod Meyerhold, Teatro Russo, Literatura Russa, Cultura Russa

ZAMBONI, Paola Fernandes. Masquerade, A Fascinating Journey From Lermontov's Play to the Stages of Meyerhold. São Paulo, 2013. Dissertação (Mestrado em 
Literatura e Cultura Russa) - Faculdade de Filosofia, Letras e Ciências Humanas, Universidade de São Paulo.

\section{Abstract:}

Mikhail Yurevitch Lermontov (1814-1841) lived in a period marked by great social upheaval, a time of transition in life and in Russian society. It was within this context that Lermontov wrote the play Masquerade, a critique of society and the petty and trivial habits of his time. Vsevolod Emilevitch Meyerhold (1874-1940) premiered his Masquerade on February 25, 1917 in the midst of a revolution that would overthrow the monarchy and transform the old Russia. After almost six years of preparations and rehearsals, the costumes, props and scenery created especially for the piece were ready for what would be both the end of an era and the birth of a new kind of theatre. This dissertation aims to analyze the Masquerade from its genesis in the romanticism of Lermontov to the spectacular production of 1917 and its effect on theatre.

Key-words: Mikhail Lermontov, Vsevolod Meyerhold, Russian Theatre, Russian Literature, Russian Culture. 
Sumário:

Introdução

Capítulo 01

LIÉRMONTOV, A MASCARADA E O ROMANTISMO RUSSO

O LEVANTE DECEMBRISTA E O NASCIMENTO DO ROMANTISMO

RUSSO

19

A IMPORTÂNCIA DE BYRON NA CRIAÇÃO DA PERSONA LITERÁRIA ROMÂNTICA 27

ENCRUZILHADAS DO INDIVIDUALISMO ROMÂNTICO NA RÚSSIA 32

MITO BIOGRÁFICO OU FORÇA DO DESTINO 38

Capítulo 02 MEYERHOLD E GOLOVIN NOS TEATROS IMPERIAIS 63 A MASCARADA DE MEYERHOLD E GOLOVIN 69 AS ORIGENS $\quad 72$ A PESQUISA $\quad 75$ A MONTAGEM 78 OS DESDOBRAMENTOS 87 Bibliografia 102 Anexo 106 


\section{Introdução}

A cidade estava vazia, ao longe ouvia-se tiros, durante todo o dia as pessoas marchavam com cartazes e palavras de ordem pedindo pão. Ainda assim, na noite da estreia, o teatro estava lotado, o tsar estava presente, assim como boa parte da aristocracia russa. Foi neste clima de tensão social, luxo e ostentação que a Mascarada de Meyerhold teve sua primeira apresentação.

E que avant première! O encenador Meyerhold e Golovin, cenógrafo do Aleksandrínki, passaram quase seis anos trabalhando nos desenhos e projetos do cenário, figurinos, objetos de cena e atuação. Cada detalhe foi delicadamente estudado e reconstruído com perfeição pela dupla: das cartas de baralho ou uma pequena luminária, vestidos, máscaras e fantasias até os ricos véus e cortinas que decoravam o palco e, em momentos chave, o dividiam trazendo a cena para frente em uma espécie de close-up que, tanto quanto a revolucionária forma de atuação, mudaria a história do teatro.

Vsiévolod Emilevitch Meyerhold (1874-1940) é um dos mais importantes encenadores do século XX. Segundo Béatrice Picon-Valin, foi um dos artistas que mais avançaram na reflexão do encenador sobre seus instrumentos de trabalho e sobre os métodos de colaboração entre aqueles que fazem teatro; ele buscou racionalizar os processos de criação, perceber as constantes e precisar a terminologia do ofício, lançar, enfim, as bases de uma complexa profissão artística em constante transformação. Como também demonstra Arlete Cavaliere em Inspetor Geral de Gógol/Meyerhold, Vsiévolod Meyerhold "foi o exemplo mais precoce e 
perfeito, visto que, durante os quarenta anos de sua vida criativa, ele inventa a maior parte das formas segundo as quais os palcos do século passado vão, conscientemente ou não, viver e se desenvolver, no que diz respeito tanto a teatro, quanto a ópera, cinema ou teatro musical."1

O próprio Liérmontov não poderia esperar uma Première mais extraordinária para seu drama. Escrita entre 1834 e 1836, a primeira versão com três atos, não foi aprovada pelo terrível departamento censura do tsar Nicolau I. Liérmontov ainda tentou apresentar outras duas versões acrescentando um quarto ato e o personagem do Desconhecido como força motriz do destino, mas não conseguiu a aprovação. Mascarada nunca seria encenada durante a curta vida de seu autor.

Tendo como base o individualismo romântico como forma de crítica à sociedade, a peça conta a história do exímio jogador Arbiénin que, depois de casado e afastado das mesas de carteado, se vê enlaçado numa cadeia de intrigas, ciúme e desconfiança que o leva a um final trágico de morte e loucura. Liérmontov foi um dos maiores poetas românticos de sua época como comprovam os versos que compõem Mascarada, tanto que para sublinhar a ideia de que a metáfora que seu herói e protagonista escolhera para a vida estava errada, foi capaz de quebrar as normas do gênero e introduzir uma figura simbólica - o desconhecido - em um drama romântico.

Mikhail lúrevitch Liérmontov (1814-1841) morreu aos 27 anos em um duelo, deixou como legado diversos poemas, o romance O Herói do Nosso Tempo,

\footnotetext{
${ }^{1}$ Picon-Valin, Béatrice, in Teatro russo: literatura e espetáculo. Ateliê Editorial, 2011, p. 215.
} 
traduzido para o português por Paulo Bezerra e algumas peças de teatro, entre elas Mascarada, sublimemente montada e remontada por Meyerhold durante quase duas décadas depois daquela fatídica noite em fevereiro de 1917. Como disse Solomon Volcov, "nem com todo o seu fatalismo pessimista ele [Liérmontov] poderia prever que a Mascarada - O Ocaso do Império, segundo os atores - seria o último ato da velha Rússia, batida pelas ondas revolucionárias. Tal coincidência Ihe teria parecido o cúmulo da ironia romântica."2

A presente dissertação se propõe a mostrar os caminhos que Mascarada seguiu através da pena de Liérmontov, dos desenhos e cores de Golovin, da genialidade inventiva do encenador Meyerhold até os palcos do Aleksandrínski e além.

\footnotetext{
${ }^{2}$ Volkov, Solomon, São Petersburgo: Uma História Cultural. Record, Rio de Janeiro, 1997, p. 217.
} 


\section{LIÉRMONTOV, A MASCARADA E O ROMANTISMO RUSSO}

Mikhail Liérmontov concebeu a peça Mascarada em meados dos anos de 1835, mas, recusada pela censura mesmo depois de diversas revisões, o autor nunca chegou a ver a peça encenada. Com a estreia da montagem de Meyerhold em 25 de fevereiro de 1917 na noite da revolução que já tomava as ruas, a peça se tornou, segundo o tradutor e eslavista italiano Ângelo Maria Ripelino, "não somente a síntese e a conclusão do teatro 'convencional', como também o réquiem, o apogeu, o monumento de uma época da arte russa". ${ }^{3} \mathrm{O}$ drama de Liérmontov não poderia ter melhor estreia. Foi escrita dez anos depois do levante decembrista que tentou, sem sucesso, impedir a coroação do Tsar Nicolau I em 14 de dezembro de 1825 levando à morte ou ao exílio alguns dos mais brilhantes representantes da sociedade russa.

Mascarada reflete uma época de perda das ilusões que sucedeu a derrota dos decembrista e ilustra o clima de estagnação. No foco da peça estão algumas das preocupações banais com que tradicionalmente se ocupava a elite da aristocracia russa: jogos de carta, duelos e bailes de máscaras; passatempos que também eram comuns na década anterior, mas de forma bem mais ingênua e que tiveram o interesse renovado na década de trinta do século XIX, abordando tal renovação com cautela, senão com um olhar crítico. As três atividades separadas e por si só diferentes, têm algumas coisas em comum: todas expressam a necessidade de se render ao desconhecido e à sorte como para evitar a dominação

\footnotetext{
${ }^{3}$ Ripelino, Angelo Maria. O truque e a Alma, Perspectiva, 1996, p. 197.
} 
total do Tsar, de suas patrulhas e escapar do controle social e cultural que havia se tornado intolerável. A nobreza russa, esmagada pelas punições e incapaz de manifestar sua individualidade ou dignidade, precisava recorrer a manifestações um tanto forçadas dessas qualidades. Dessa maneira, jogatinas, duelos e bailes de máscaras são testemunho não tanto da depravação das classes governantes, mas da busca desesperada por independência, anonimato e fuga do controle totalitarista, como coloca o professor e eslavista Vladimir Golstein em seu livro Liermontov's Narratives of Heroism ${ }^{4}$.

Num breve resumo da peça, Arbiénin, o protagonista, encontra o Príncipe Zvézdich numa jogatina depois que este já perdeu boa parte de seu dinheiro. Antes um exímio jogador, Arbiénin decide jogar pelo príncipe e rapidamente recupera o dinheiro perdido. Depois de tal virada na "sorte", os dois homens vão para um baile de máscaras onde a Baronesa Strahl, escondida atrás de uma máscara, usa o anonimato para seduzir o Príncipe. Alarmada pelo desejo do Príncipe em transformar o flerte num caso de amor, a Baronesa decide se proteger apontando Nina, esposa de Arbiénin, como autora das provocações. Com a ajuda do repugnante Chprikh, espalha rumores de que Nina está tendo um caso com o Príncipe até que, iludido pela Baronesa, Zvézdich começa a perseguir a esposa de Arbiénin, o que, por sua vez, leva ao ciúmes de Arbiénin, mais desentendimentos e ao assassinato de Nina.

Eis como se desenvolve a ação:

\section{Primeiro ato}

\footnotetext{
${ }^{4}$ Golstein, Vladimir. Liérmontov's Narratives of Heroism, Northern University Press, 1998.
} 
Cena I - Os jogadores na banca dizem que Arbiénin, tendo feito fortuna como jogador profissional, desistiu das cartas depois de ter encontrado a felicidade no casamento com uma jovem e inocente mulher, Nina. Arbiénin aparece para uma nostálgica visita a seu antigo covil. Ele até volta a jogar, não para si mesmo, mas para recuperar a fortuna do jovem príncipe Zvésditch, que acabara de perder tudo. Depois da vitória de Arbiénin nas cartas, os dois resolvem ir juntos ao baile de máscaras.

Cena II - Uma dama mascarada, a baronesa Strahl, está flertando abertamente com o príncipe, que a pressiona para que ela the dê um memento deste encontro, com o qual ele espera depois ser capaz de descobrir sua identidade. Nina também está no baile de máscaras, mas rejeita um flerte, o gesto que faz para escapar acaba por desprender de seu pulso um bracelete, que cai despercebido no chão. A baronesa o encontra e, sem saber a quem pertence, o dá ao príncipe, de modo a demovê-lo de sua perseguição. O príncipe mostra o bracelete a Arbiénin, que, embora intrigado que este lhe pareça familiar, encoraja-o a procurar pela dona.

Cena III - De volta em casa, Arbiénin fica surpreso ao descobrir que sua mulher foi à mascarada, de onde ainda não voltou. Quando ela enfim retorna, exprimem seu amor mútuo, embora ela admita que se sente sozinha e deseja que o marido 
pudesse passar mais tempo com ela. Acariciando sua mão, Arbiénin nota que o bracelete não está lá e sucumbe a um ataque de ciúmes, percebendo que era idêntico ao memento da conquista que o príncipe the havia mostrado no baile de máscaras.

\section{Segundo ato}

Cena IV - Numa visita matinal à baronesa o príncipe confidencia que viu Nina tentando encontrar um bracelete igual em uma loja. Quando Nina chega, ele tenta obter a recompensa que o memento supostamente lhe garantia, mas é repelido com indignação. Agora que a baronesa sabe quem é a dona do bracelete, também encoraja o príncipe a pressionar Nina ainda mais ao invés de admitir que havia sido ela a quebrar o decoro e dar-Ihe a joia. Para completar a intriga ela conta a seu visitante seguinte, o mesquinho e fofoqueiro Schprikh, que Nina e o príncipe Zvézditch estão tendo um caso.

Cena V - Na manhã seguinte, em casa, Arbiénin está pronto para esquecer suas suspeitas a respeito de Nina. Enquanto esperam por ele Schprikh e o jogador Kazárin, comentam que a ligação entre Nina e Zvézditch já era de conhecimento de todos, Arbiénin, com uma carta endereçada a 
Nina nas mãos, entra sem notá-los e abjura da virtude pra sempre anunciando que está pronto para matar.

Cena VI - apesar de o criado do príncipe negar que ele esteja em casa, Arbiénin encontra o caminho até o quarto em que Zvézditch dorme, mas hesita em matar o jovem dormindo. Ao invés disso, planeja desonrar o príncipe e deixa um bilhete convidando-o a uma mesa de jogo. Em sua fúria de vingança ele arranca o véu de uma dama que entra na casa do príncipe pensando que podia ser Nina. Ao descobrir a Baronesa ao invés de sua esposa, passa por ela sem dar ouvidos à confissão de que havia sido ela a envolver tanto o príncipe quanto ele nesta intriga.

Cena VI - O príncipe também não deu atenção nem à confissão da baronesa, nem à advertência sobre o ciúme doentio de Arbiénin. Ele aparece pra jogar e Arbiénin dá as cartas com tanta maestria enquanto conta uma anedota que logo pode levantar-se e acusar o príncipe de trapaça. Arbiénin nega ao príncipe até mesmo a satisfação de um duelo, dizendo quem não se pode duelar com um trapaceiro.

\section{Terceiro Ato}

Cena VIII - Apesar de ter sido publicamente enjeitado no baile em sociedade, o príncipe procura Nina para devolver o bracelete, enquanto isso Arbiénin observa este gesto de longe. 
Tendo confirmado suas suspeitas, Arbiénin condena Nina a morte por envenenamento, veneno este que ele carrega há muito tempo para o caso de uma perda irreversível nas cartas fazer necessário o suicídio. Nina canta para os convidados e depois pede ao marido um refresco. Arbiénin joga o veneno em uma porção de sorvete e serve para Nina, que o toma sem desconfiar de nada.

Cena IX - Arbiénin trouxe Nina para casa, mas apesar dela se sentir mal, manda que sua criada saia e tranca a porta do quarto recusando-se a chamar um médico. Ele diz a Nina que ela morrerá e exige que admita sua infidelidade. Mesmo reafirmando total inocência em suas últimas palavras, Arbiénin não acredita nela.

\section{Quarto Ato}

Cena $X$ - No velório de Nina o receio de que estivesse errado se confirma em uma carta do príncipe. Ainda assim, Arbiénin não teme ser punido por seu crime até que o Desconhecido que já o tinha ameaçado na mascarada reaparece entre as pessoas de luto para dizer que tinha visto Arbiénin derramar veneno no sorvete que deu para Nina durante o baile. Depois de ouvir os motivos por trás da perseguição do Desconhecido, Arbiénin enlouquece ao perceber que sua arrogância e egocentrismo levaram ao ciúme 
doentio e à morte de uma inocente, aquela que poderia ser a sua única salvação do submundo decadente em que circulava.

O complexo mecanismo desta intriga e de seu final trágico se baseia em cinco personagens: o jovem príncipe Zvézditch, um tolo oficial de São Petersburgo, herói de aventuras duvidosas, encarnação da mascarada e também das regras vulgares da sociedade; a baronesa Shtral, uma mulher inteligente que avalia a vida de forma sutil, preocupada com sua reputação perante as altas rodas, ainda que sua paixão sincera não desperte a capacidade fazer sacrifícios; Kazárin, jogador e trapaceiro dono de uma filosofia cínica tanto para a vida quanto para o jogo; Chprikh, espião e conspirador por natureza que com baixos serviços galgou seu acesso aos graus superiores da sociedade (o protótipo é o do homem inferior, possivelmente um agente do Terceiro Departamento, órgão de censura e repressão de Nicolau I); o Desconhecido, personagem sinistro e misterioso, dono de uma biografia particular cheia de ressentimento vingativo contra Arbiénin, o motivador de sua presença na peça, ao mesmo tempo, sua hostilidade para com o anti-herói Arbiénin faz dele uma espécie de símbolo de luz.

Poeta lírico acusado de monologismo byroniano, Liérmontov sonhava começar sua carreira com o gênero que por excelência representava diversos estados de consciência. Na peça de quatro atos, escrita em verso entre 1834 e 1836, Liérmontov aborda certos traços do romantismo de uma maneira peculiar e sugestiva onde ideais se perdem em ideologias. ${ }^{5} \mathrm{Na}$ trama de Mascarada podemos detectar uma intertextualidade implícita tanto com Otelo, de Shakespeare, quanto com Amor e Intriga, de Schiller. Um tipo de dialogismo que foi destacado por Boris

\footnotetext{
${ }^{5}$ Elizabeth Cheresh Allen. Unmasking Liérmontov's "Masquerade": Romanticism as Ideology. : // The Slavic and East European Journal, Vol. 46, No. 1 (Spring, 2002), pp. 75-97.
} 
Eikhenbaum, em sua análise do drama no ensaio "Cinco redações de Mascarada": "Os gostos dramáticos e teatrais de Liérmontov foram educados, de um lado, por Schiller e o Sturm und Drang, por Shakespeare - por outro, pelo drama romântico francês e o melodrama que dominou o repertório teatral russo dos anos 20 - 30 . Para isto tem de adicionar a tradição da comédia russa em verso. Mascarada - é uma peça de gênero misto: ora ela se torna um tipo de comédia satírica como "Desgraça de ser inteligente" (todo o papel de Schprikh), ora se eleva a uma tragédia lírica (nos monólogos de Arbiénin). Esta tragédia não é psicológica, mas social e filosófica, nesse sentido, foi escrita antes na esteira de Schiller, do que na de Shakespeare. A figura de Arbiénin está organicamente ligada às imagens do Demônio e de Vadim do jovem Liérmontov: esta é sua variante dramática. A psicologia não tem nada a ver com isso: desta forma, o personagem de Arbiénin não pode ser compreendida ou revelada. A base de "Mascarada" - não é a psicologia, não é a paixão em si, não é a construção e o desenvolvimento dos personagens, mas a filosofia de comportamento: o problema da relação entre o bem e o mal."

Ainda segundo Elisabeth Cheresh Allen em Unmasking Lermontov's "Masquerade": Romanticism as Ideology ${ }^{7}$, as apreciações de Mascarada e suas variações tendem a se dividir na mesma linha da crítica sobre Liérmontov em geral. Alguns trataram a peça como uma tragédia romântica sobre um nobre de espírito byroniano que sucumbe a um destino implacável pela força de sua própria personalidade; enquanto outros consideram Mascarada um retrato satírico pungente de uma sociedade perniciosa, o que antecipa as tendências realistas de Liérmontov.

\footnotetext{
${ }^{6}$ Эйхенбаум Б. Пять редакций "Маскарада" // Лермонтов М. Ю. Маскарад: Сб. ст. - М.; Л.: Изд. ВТО, 1941. - С. 99.

${ }^{7}$ Elizabeth Cheresh Allen. Unmasking Liérmontov's "Masquerade": Romanticism as Ideology. : // The Slavic and East European Journal, Vol. 46, No. 1 (Spring, 2002),
} 
Para melhor compreender a questão, é preciso entender as origens e peculiaridades do romantismo na Rússia.

\section{O LEVANTE DECEMBRISTA E O NASCIMENTO DO ROMANTISMO RUSSO}

Como na maior parte da Europa, o romantismo na Rússia surgiu no encalço de eventos históricos marcantes e extensas mudanças nas instituições literárias. A frustrada invasão napoleônica e a subsequente ocupação de Paris pelo exército russo em 1815 elevou os espíritos nacionalistas e ajudou a enraizar a ideia romântica de que a Rússia teria um papel histórico a cumprir no cenário europeu e quiçá internacional, o que contribuiu para consolidar a preferência da literatura russa em geral, por questões nacionais como história da Rússia, o desenvolvimento de uma literatura nacional e a codificação de uma linguagem padrão em lugar de temas como o individualismo e o fantástico, amplamente explorados no repertorio europeu.

Certos eventos consecutivos ajudaram a moldar o romantismo na Rússia e determinar a forma que veio a adquirir, dentre eles, talvez, o mais importante tenha sido o levante histórico que se seguiu à derrota de Napoleão. Em dezembro de 1825, logo após a morte de Alexandre I e a ascensão do impopular e despótico Nicolau I, um grupo de nobres e oficiais russos, inspirados por ideais patrióticos e liberais trazidos da ocupação de Paris entre 1815 e 1818, junto com noções de uma monarquia iluminista, organizou um golpe de estado que foi abafado sem 
dificuldades, levando Nicolau I a tomar de imediato medidas extremamente impopulares para reforçar o governo autocrático.

O Tsar foi implacável com aqueles que participaram do levante: mandou 120 deles para o exílio às margens do lago Baikal na Sibéria e, pessoalmente, comandou a execução de cinco decembristas, como ficaram conhecidos os nobres e oficiais que participaram do levante. Em consequência, as políticas adotadas em resposta por Nicolau I criaram uma atmosfera rigorosamente repressiva, especialmente para os intelectuais e artistas. As viagens ao exterior foram drasticamente reduzidas ao mesmo tempo em que ele se esforçava por cortar pela raiz o "pensamento livre" onde quer que este se encontrasse ou suspeitasse que poderia existir. Em 1826, criou uma nova força policial extremamente ativa - o assim chamado Terceiro Departamento - cuja função era identificar e reportar semeadores de ideias perigosas. Tais medidas tiveram um impacto profundo na elite pensante da sociedade russa. Como explica o professor e eslavista David Powelstock, as novas políticas fortaleceram a percepção da aristocracia russa de que não podia gozar mais dos mesmos direitos e liberdades disponíveis para a elite europeia, deixando claro para esta aristocracia que nenhuma forma de dissidência seria tolerada e jogando uma mortalha de autocensura e desconfiança mutua até mesmo sobre a mais inocente reunião intelectual. Muitos dos decembristas mortos ou exilados eram ativos participantes na pequena rede de círculos literários que haviam se estruturado na década anterior. O exílio imposto a estes intelectuais pelo "Tsar de ferro", como ficou conhecido o implacável Nicolau I, abalou os ânimos daqueles que ficaram para trás, Púchkin entre eles.

A censura era o inimigo oficial depois do levante decembrista e das medidas repressivas de Nicolau I e, sob as condições impostas, onde era difícil, senão 
praticamente impossível, exprimir-se abertamente sobre ideais políticos ou sociais, a literatura tornou-se o único veiculo em que tais ideias, ainda que cripticamente, podiam ser transmitidas. Um programa que convidava a ignorar a repulsiva e, depois dos decembristas, também perigosa, cena política e concentrar-se no aperfeiçoamento moral, pessoal, literário e artístico. O mais importante efeito da repressão foi mover as ideias políticas e sociais para a esfera relativamente segura da literatura. Um fato que já havia ocorrido na Alemanha e se repetia, em maior escala, na Rússia.

A conexão entre romantismo, identidade nacional e histórica era especialmente forte na Rússia dos anos de 1820 e 1830. Os românticos europeus procuravam pelo fio de ouro da identidade nacional imanente na tessitura do passado e, dessa forma, tentavam expressá-lo nas páginas dessa nova literatura que iria, por sua vez, ratificar as credenciais russas e historicamente assentá-la como um membro único e adequado, senão superior, neste seleto grupo de nações modernas. Segundo o eslavista norte-americano David Powelstock:

"Não chega a ser uma surpresa que muitos dos escritores do período - Karamzin, Púchkin e os decembristas à frente - se ocupassem simultaneamente com a literatura e a história. (...) Ainda assim, tais autores eram agudamente conscientes de que história e literatura representavam duas esferas distintas e contrastantes, cada uma com seus próprios padrões de verdade." 8

\footnotetext{
${ }^{8}$ Polwelstock, David: Becoming Mikhail Liérmontov: the ironies of romantic individualism in Nicholas I's Russia. Northwestern University Press, Evanston, Illinois, 2005, p. 46
} 
Esta condição cultural, social e política prevalecente na Rússia dos anos de 1830 agravava o conflito que aparentemente havia se tornado uma característica permanente da vida russa, o conflito entre "civilização e servidão" (segundo a definição de A. Herzen), ou seja, entre os valores ideológicos inspirados pelo ocidente e a realidade repressiva da Rússia, o dilema entre os valores libertários e individualistas do romantismo e a despótica repressão social e cultural reinante depois do levante decembrista. Tentando parecer com europeus progressistas e iluministas de um lado, e obedientes russos tementes a Deus e ao Tsar de outro, a elite russa educada recorria à eterna mascarada a que se refere Vladimir Golstein, a qual abrangia não só as esferas políticas e sociais, mas, também, a esfera cultural e pessoal.

Esta falta de modelos comportamentais legítimos em uma época de confusão, desorientação e perseguição social é o que tornou a contribuição de Liérmontov para a literatura russa tão significativa. Sua representação literária (e psicológica) de diferentes heróis, dentre eles o mais conhecido é o polêmico Pietchórin, protagonista do romance O Herói do Nosso Tempo (1840), que é na literatura russa, como diz Paulo Bezerra:

"a primeira experiência de romance centrado em um processo de análise da personalidade de um indivíduo, que tem sua vida estudada a partir de sua interioridade, o que faz dessa obra um romance analítico que antecipa o psicologismo que Dostoiévski iria usar como procedimento literário na construção de seus romances. Dostoiévski, que se reconheceu descendente de O Capote de Gógol, guardadas as devidas 
diferenças é também um descendente da poética de Liérmontov $^{9}(\ldots) "$

Liérmontov apresentou ao público russo da época os únicos modelos de comportamento existentes fora dos padrões estabelecidos de humilhação religiosa, resignação social ou revolta indiscriminada. Para Vladimir Golstein, "Liérmontov parece sugerir que é perigoso, fútil e desonesto para um indivíduo - particularmente dentro do contexto russo - voltar-se para fórmulas prontas de obediência, servidão e auto renúncia." ${ }^{10}$ Por outro lado, como vemos em Mascarada, a insurreição e a revolta frequentemente rejeitam qualquer responsabilidade individual com os outros. A subversão irresponsável de Arbiénin tanto quanto jovem como mais tarde para se vingar do príncipe vem a causar tanto estrago que termina em morte, ruína e loucura.

A literatura e as artes sempre serviram de porta de entrada e certamente foram o meio mais comum de introduzir o público russo ao equivalente a séculos de desenvolvimento cultural, político, social, econômico e legal do ocidente. Dessa forma, o romantismo veio a ser uma força cultural extremamente importante. A preocupação com a condição do ser, a rebeldia e até mesmo o demonismo ofereceu aos artistas e, ultimamente, ao público russo uma oportunidade para repensar a própria matéria que formava a personalidade humana e renegociar sua posição dentro da sociedade e do universo. Liérmontov, no entanto, sempre esteve ciente das consequências potencialmente trágicas que tais ideais românticos como o individualismo e principalmente a auto afirmação traziam em seu bojo.

\footnotetext{
${ }^{9}$ Bezerra, Paulo. Introdução a O Herói do Nosso Tempo, São Paulo, Martins Fontes, 1999, p. XV.

${ }^{10}$ Golstein, Vladimir. Liérmontov's Narratives of Heroism, Northern University Press, 1998, p. 26.
} 
O fascínio com o demonismo foi revivido durante o período romântico, muitos poetas identificavam poesia com rebelião, exílio, perda e, por sua vez, rebeldia com satã. Liérmontov não era exceção. Quando leu o poema "Demônio," o príncipe Mikhail Romanov notou: "primeiro tivemos o Belzebu italiano, depois o Lúcifer dos ingleses, o Mefistófeles alemão e agora o Demônio russo apareceu. Bem, há um aumento nas forças do mal." E acrescenta maliciosamente, "resta saber quem inventou quem: Liérmontov o espírito do Mal ou o Espírito do Mal a Liérmontov." (citado em Gershtein, 1986, 73). ${ }^{11}$ A despeito da negatividade, a afirmação do príncipe pressagiou as duas maiores correntes críticas sobre o poema, preocupadas, principalmente, em colocá-lo ente a tradição diabólica europeia ou em encontrar as raízes para o demonismo de Liérmontov, crítica ecoada por figuras ilustres como Dostoiévski, que acreditava que a solução para a problemática do herói romântico cheio de orgulho era tornar-se mais humilde e mais de uma vez usou como exemplo os aspectos negativos de personagens demoníacos, em especial Pietchórin, para construir alguns de seus próprios, como Stavróguin de Os Demônios $^{12}$; e Vladimir Soloviov, por sua vez atacava mais os demônios do cristianismo do que o demônio metafísico de Liérmontov atribuindo a maldade ao egoísmo, ao individualismo e ao afastamento de Deus ${ }^{13}$. Eikhenbaum assim analisa a figura demoníaca de Arbiénin em Mascarada:

"A figura de Arbiénin está organicamente ligada à figura do Demônio, excluindo qualquer ideia de punição ou castigo. Os monólogos de Arbiénin e, repetidamente, forçando a

\footnotetext{
${ }^{11}$ Golstein, Vladimir - Liérmontov's Narratives of Heroism, Northern University Press, 1998. p. 29

${ }^{12}$ Bezerra, Paulo. Introdução a O Herói do Nosso Tempo, São Paulo, Martins Fontes, 1999, p. XVI

${ }^{13}$ Golstein, Vladimir - Liérmontov's Narratives of Heroism, Northern University Press, 1998, p. 1067.
} 
lembrar de texto "Demônio" adicionando a "Mascarada" um profundo significado alegórico, indo muito além do assunto em si e revelando a verdadeira intenção do autor: mostrar a tragédia da sociedade humana, disposta de modo que a busca real e ativa do bem, do rico ideal e da vontade, inevitavelmente assume a forma do mal - o ódio, a vingança. E morrerá vítima deste mal a inocência - uma alma, pura e infantil: Tamara em "O Demonio", Olga em "Vadim", Nina em "Mascarada". O espectador, ouvindo os monólogos de Arbiénin (se não forem distorcidos pela falsa interpretação "psicológica" do ator), deve experimentar uma luta complexa: a compaixão natural por Nina em conflito com uma simpatia filosófica por Arbenin - como um sofredor, que perdeu sua única esperança de salvação. Esta é a compaixão mais difícil exigida por Liérmontov e seu demônio, matando Tamara; e para a seu Vadim, destruindo a felicidade de Olga; e seu perverso Alexander ("Dois Irmãos"). Aqui, esta dupla e aparentemente contraditória compaixão, que imprime no espectador equilíbrio moral, é o papel da filosofia, a profundidade dialética de "Mascarada" - Toda a verdade, o poder e a intensidade da obra de Liérmontov. "14

Enquanto Aleksander Púchkin mostrou a derrota de sua personagem byroniana, Aleko ("Os Ciganos"), pelas ações imorais e inconsistentes dele, Liérmontov vai além ao fazer seu herói byroniano, Arbiénin, experimentar e

\footnotetext{
${ }^{14}$ Эйхенбаум Б. Пять редакций "Маскарада" // Лермонтов М. Ю. Маскарад: Сб. ст. - М.; Л.: Изд. ВТО, 1941. - С. 100-101.
} 
reconhecer o colapso de sua filosofia. Arbiénin passa por uma queda intelectual: tendo confrontado o fato que sua imagem de si mesmo como a de um guerreiro contra os males do universo se tornou inadequada e levou à morte de uma pessoa, ele literalmente perde a cabeça. Seu erro é aquele do homem orgulhoso. Ver o mundo como um lugar de bondade é uma iniciativa ingênua e perigosa. Arbiénin já tinha visto muitos jovens cândidos e ignorantes sendo esmagados pela crueldade da vida. Ainda assim, tomar o caminho oposto é igualmente perigoso. De fato, a sedução demoníaca de uma representação gnóstica, parece ser a principal tentação contra a qual, assim como seus protagonistas, Liérmontov luta. Este confronto com o demônio do gnosticismo constitui o conflito principal em muitos dos textos mais importantes do poeta. Mascarada, contudo, é a primeira resposta séria de Liérmontov à filosofia da onipotência do mal. Arbiénin, o primeiro herói de seu tempo, divide com os personagens tardios de Liérmontov, sua força, orgulho, independência, autoconfiança e nobreza. E como eles, Arbiénin tem de encarar a luta tanto contra o mal existente que alimenta sua perspectiva gnóstica quanto essa própria perspectiva. Através do compromisso de Arbiénin, Liérmontov revela que a perspectiva gnóstica, ainda que tentadora, é prova de sua própria ruína. Ao ver o mal por toda parte, suspeitando de tudo e de todos, Arbiénin, a despeito de todo o seu orgulho, autoconfiança e recusa a se submeter ao mal sob pressão, sucumbe a esse mal e é levado à falência intelectual e à loucura. ${ }^{15}$

Ao contrario dos iluministas, Liérmontov abraçava a complexa, contraditória e precária posição do individuo perante a sociedade e a vida, vendo a liberdade que o herói romântico conquistara como um destino potencialmente trágico. Ele deixa,

\footnotetext{
${ }^{15}$ Golstein, Vladimir - Liérmontov's Narratives of Heroism, Northern University Press, 1998, p. 83.
} 
contudo, a tarefa de condenar o demonismo, o narcisismo ou a rebeldia romântica de uma personalidade superdesenvolvida a outros escritores.

Numa sociedade onde a livre expressão da individualidade é fortemente desencorajada, senão suprimida, tende-se a fazer o que é esperado e aceitável; ou seja, usar máscaras elegantes e familiares como as usadas no baile de máscaras da Mascarada, que permitiam aos cortesãos praticar toda sorte de intrigas e dissimulações, mas, também, as máscaras empunhadas em sociedade, como a do exímio jogador que não pode ser ludibriado, a da grande dama cuja "honra" deve permanecer ilibada ou a do galanteador que precisa a todo custo perseguir suas conquistas. É durante o baile da alta nobreza de São Petersburgo (uma referência explícita aos famosos bailes da alta sociedade na casa dos Engelhardt que Liérmontov frequentava na época) que a rede de intrigas e enganos que culminará com a morte de Nina começa a ser tecida. A metáfora é brilhante: com os rostos cobertos as almas estão livres e o verdadeiro caráter é desmascarado. Mas, como qualquer engodo, esta mascarada não é saudável, ao contrario, é, como no caso da pura e ingênua Nina, destrutiva e fatal. A intricada teia de ligações entre as esferas sociais e literárias na cultura da época de Liérmontov era mais bem tecida nas práticas relativas ao amor e ao ato de cortejar. Assim, ler poesia se tornava, talvez, a atividade mais eroticamente excitante em que os jovens dos tempos de Liérmontov podiam se ocupar. ${ }^{16}$

\section{A IMPORTÂNCIA DE BYRON NA CRIAÇÃO DA PERSONA LITERÁRIA ROMÂNTICA}

\footnotetext{
${ }^{16}$ Berlin, Isaiah. Russian Thinkers. Penguin books, 1994.
} 
Golstein aponta que o poeta simbolista e crítico Viatcheslav Ivánov reconhece o débito cultural profundo da Rússia para com o romantismo e seu ethos individualista, em seu ensaio "Byronismo como um Evento na Vida do Espírito Russo" (1916) Ivánov diz: "nós, os eslavos, descobrimos a revelação social da personalidade humana nas profundezas do espírito inglês. Tal revelação foi o byronismo. "17

$\mathrm{Na}$ época em que Liérmontov começou a escrever seus primeiros versos, os ícones do individualismo romântico, Byron e Napoleão, já estavam mortos. Mesmo assim, entre 1830 e 1832, Byron serviu como o principal modelo romântico de poeta individualista, uma persona onde a vida e a obra se entrelaçavam numa imagem autêntica e reconhecível. Para ele, Byron, assim como Napoleão eram figuras imortais por causa de seus destinos e das virtudes de suas conquistas e serviam de modelo comprovado para a imortalidade histórica que ele também procurava atingir. O fascínio de Liérmontov por Byron não estava somente na obra do poeta inglês, mas na relação entre vida e poesia que ele reconhecia na saga do jovem poeta. Em Byron, ele descobriu uma figura onde a existência histórica e o significado icônico se encontravam fortemente amalgamados à criação poética, um poeta cujos versos expressavam a inter-relação entre vida e arte como a autêntica individualidade romântica sine qua non. ${ }^{18}$ Liérmontov preferia Byron a outros heróis românticos como Napoleão, afirma Powelstock, por causa do sucesso do poeta inglês em transformar a si mesmo no próprio mito do poeta herói. Ao combinar sua dramática biografia com uma obra literária que refletia temas e valores inerentes ao homem, o mito de Byron forjou o processo de transfiguração através do discurso que Liérmontov tanto almejava.

\footnotetext{
${ }^{17}$ Golstein, Vladimir. Liérmontov's Narratives of Heroism, Northern University Press, 1998, p. 13-14

${ }^{18}$ Polwelstock, David: Becoming Mikhail Liérmontov: the ironies of romantic individualism in

Nicholas l's Russia. Northwestern University Press, Evanston, Illinois, 2005, p. 78
} 
Depois do fracassado levante decembrista em 1825, os intelectuais exilados continuaram a ter afinidade com Byron, mas seu próprio sofrimento e a execução de seus camaradas russos em grande parte ofuscou a vida e a sorte do poeta inglês. Ao mesmo tempo, uma nova geração de poetas, que entrava em cena na esteira desses eventos históricos, via Byron sob uma luz menos política do que a anterior. A personalidade e o comportamento de Byron tinham mais importância para estes jovens do que seus ideais. Foi nesse ponto que os jovens russos começaram a adotar a "pose byroniana" em público. O jovem Arbiénin mostra este comportamento com o copo de limonada em uma das mãos e o veneno na outra:

“(..) Faz dez anos, quando me iniciava no caminho da corrupção, certa noite perdi no jogo até o último centavo; naquele tempo eu não sabia o preço do dinheiro nem o preço da vida. Estava desesperado e fui em busca de algum veneno. Depois de tê-lo comprado voltei à mesa de jogo, o sangue me ardia no peito, em uma das mãos tinha preparado o copo de limonada e na outra uma carta, o último rublo no bolso esperava seu destino junto ao desfecho fatal, o risco era realmente grande, mas, a felicidade me salvou e em uma hora recuperei tudo o que havia perdido. Desde aquele dia guardo este veneno como um talismã misterioso e é estranho que me defenda nos dias agitados e o tenha guardado para a hora negra da minha vida. E esta hora chegou." 
Para Liérmontov, o "desespero titânico" de Byron, ecoava o senso de alienação pessoal que ele sentia por causa do cada vez mais repressivo regime de Nicolau I e da sociedade petersburguesa que se encolhia sobre ele, mas também pela perda da heroica geração de seus antepassados, os decembristas. ${ }^{19} \mathrm{O}$ dom literário do jovem Liérmontov começa a se formar somente no final da década de 1820, nessa época Byron já tinha morrido e virado lenda como um poeta do passado, cuja obra, vida, fama e morte tinham sido moldadas pelos leitores em algo mitológico. Para Liérmontov, no entanto, a identidade de Byron estava solidamente estabelecida de uma forma bastante particular. O poeta inglês tinha sido uma figura histórica, alguém, cuja obra criativa e a biografia tinham marcado, para um grande número de leitores, sua emblemática condição humana, mas a verdade de sua personalidade parecia tão enigmática quanto a existência que simbolizava. A personalidade de Byron era um ideal construído, contudo era também um mistério que desafiava a interpretação. O Byron de Liérmontov era o Byron humano, cuja grandiosidade era definida antes pela época em que viveu, do que por sua obra literária, que meramente refletia a vida, com todas as suas imperfeições. Mais importante para Liérmontov era a personalidade orgulhosa e sombria do herói byroniano que o distinguia dos outros homens e o destacava como um profeta de sua época, sofrendo sob o peso de seu dom visionário.

O próprio Liérmontov detestava a ideia de ser apontado como um mero imitador de Byron, já aos dezesseis anos, afirmou em uma de suas líricas, que "Não, eu não sou Byron, um outro sou” («Нет, я не Байрон, я другой»). Destacou acima de tudo que, a despeito de sua afinidade com o poeta inglês, era "de alma russa dotado". Liérmontov, no caso, queria simplesmente dizer que o essencial nele era

\footnotetext{
${ }^{19}$ Polwelstock, David: Becoming Mikhail Liérmontov: the ironies of romantic individualism in Nicholas l's Russia. Northwestern University Press, Evanston, Illinois, 2005, p. 79
} 
aquilo que era seu e não o que pegava emprestado de alguém. Ou como coloca Paulo Bezerra: "Ao comparar-se a Byron, mas enfatizando a sua condição de outro, ele aponta para a reformulação russa do modelo byroniano e, como poeta romântico, ressalta a dessemelhança no semelhante, a diferença na identidade". ${ }^{20}$

Por mais consciente que Liérmontov tenha estado ao moldar-se em Byron no inicio, com o passar do tempo, no entanto, os padrões de comportamento ali ditados podiam se tornar hábitos inconscientes. Posto de uma forma diferente, não existe uma linha clara entre a "máscara" e a identidade "real." Os gostos teatrais da alta sociedade tendiam a recompensar performances românticas "dramáticas" com a atenção, reforçando assim tais modelos de personalidade ${ }^{21}$ É a postura do príncipe Zvézdich em Mascarada que, como veremos a seguir, toma pela máscara a pessoa de Nina e dramaticamente se deixa enredar pelo engano servindo de contraponto romântico ao conflito da peça.

As metáforas da máscara e do jogo de cartas construídas por Liérmontov em Mascarada se tornam um importante fio condutor que irá permear e conduzir toda a sua obra. A hostilidade com as máscaras e o jogo está diretamente ligada a seu interesse nas questões de heroísmo e individualismo. Golstein justifica esta procura pelo herói e o ataque à mascarada como respostas de Liérmontov ao conflito cultural que aparentemente havia se tornado uma característica permanente da vida russa. Ou seja, os valores libertários e individualistas do romantismo em conflito com a repressão pós-decembrista na Rússia. Uma tensão difícil de resolver.

O período romântico foi um período de grandes heróis como Napoleão e Byron, assim como a adoração ao heroísmo e ao individualismo romântico na Rússia a exploração compreensiva do tema do individualismo só começou no século

\footnotetext{
${ }^{20}$ Bezerra, Paulo. Introdução a O Heroi do Nosso Tempo, São Paulo, Martins Fontes, 1999, p. XI.

${ }^{21}$ Polwelstock, David: Becoming Mikhail Liérmontov: the ironies of romantic individualism in

Nicholas l's Russia. Northwestern University Press, Evanston, Illinois, 2005, p. 97
} 
XIX com o advento do romantismo. Muitos dos insights do romantismo, insights que constituem somente de um pequeno capitulo na historia do individualismo no ocidente, formam um livro inteiro na Rússia. ${ }^{22}$

\section{ENCRUZILHADAS DO INDIVIDUALISMO ROMÂNTICO NA RÚSSIA}

Os russos com certeza foram infectados pelo entusiasmo do romantismo pelo individualismo e seus valores mais profundos, por outro lado, também estavam suscetíveis ao seu programa anti-iluminista, com seus ataques ao contrato social, aos direitos humanos, ao racionalismo e ao ceticismo religioso. Assim, muitos russos viam o individualismo como uma força destrutiva, explosiva, perigosa e que rompia com a própria função da sociedade e da cultura. Arbiénin, consumido pelo ciúme torna-se esta força destrutiva, insaciável em sua vingança só irá parar com a morte de Nina. As qualidades negativas associadas ao individualismo romântico - a atomização, a alienação, o egoísmo, o subsequente conflito social e a desordem estavam destinados a alarmar os russos, moldados que foram pelo constante medo de invasões e conflitos civis. O medo das explosivas doutrinas individualistas era compartilhado não somente pelo regime tzarista e a igreja, mas, também, pela maioria dos cidadãos comuns. Assim, não é nenhuma surpresa que apelos para confrontar este mal - se não pela força, por meio da religião, doutrinas místicas de estado e pessoais, ou a autorrenúncia - tornaram-se fundamentais para a retórica dos oponentes russos do individualismo. Começando com Karamzin, intelectuais russos articulavam a identidade nacional precisamente em termos da união e

\footnotetext{
${ }^{22}$ Golstein, Vladimir. Liérmontov's Narratives of Heroism, Northern University Press, 1998, p. 13.
} 
coesão social, em oposição à fixação ocidental no individualismo e seus inevitáveis conflitos.

Nenhuma outra tradição moderna europeia atribuiu tão consistentemente a poetas e novelistas tal grau de autoridade moral, social e até religiosa. Essas circunstancias fortaleceram a resistência russa ao individualismo romântico ao enquadrar a identidade social provocadora do romantismo como uma ameaça genuína à tessitura moral da sociedade. Em outras palavras, no segundo quarto do século XIX, a elite cultural russa achou-se confrontada, de um lado pelo etos romântico ocidental, com suas revoluções, declarações de direitos humanos, doutrinas individualistas e interesse literário na autoanálise, biografia e confissão; e de outro pela repressão pós-decembrista par a par com os crescentes ataques ao individualismo. A tensão deste confronto resultou num vívido debate sobre a natureza do ser humano e os limites dos direitos individuais e responsabilidades. Em Mascarada, a crítica à sociedade deixa isso patente, Liérmontov a retrata com todos os vícios, intrigas e hipocrisia. $\mathrm{O}$ individualismo de Arbiénin o carrega invariavelmente ao final trágico uma vez que, cego de ciúmes, é incapaz de ouvir a verdade. A maneira como subiu na vida, fazendo fortuna no jogo às custas da ruína de outros homens, mais do que o destino inevitável é a verdadeira razão de sua queda, não são elementos místicos que trazem o Desconhecido à mascarada e ao velório de Nina, mas, as ações de Arbiénin no passado. O etos particularmente radical de Liérmontov, no espírito elevado da não conformidade romântica, lutava conscientemente para transcender o sistema que era moralmente aceito, da mesma forma que rejeitava todas as outras ideologias sociais que concebiam o indivíduo como um apêndice da coletividade. 
A verdade, é que a vida e a obra aparentemente contraditória de $\mathrm{M}$. Liérmontov podem ser entendidas como a manifestação de um ponto de vista coerente, uma visão particularmente radical do individualismo romântico. Para avaliar adequadamente a exploração do heroísmo em Liérmontov, é preciso levar em conta a preocupação de Liérmontov com o ponto de vista social e cultural individualista do romantismo. Sua perspectiva envolvia antes de tudo a convicção de que a consciência e os desejos do indivíduo antecedem em importância qualquer definição do individual em termos coletivos.

No drama Mascarada nenhum dos personagens, com exceção quem sabe de Nina e do Desconhecido, parece realmente consciente de seu papel tanto na sociedade naquele dado momento retratado na peça, quanto de si mesmos. Assim, o príncipe deixa-se enganar pela baronesa em seu ritual de corte; a baronesa inadvertidamente arma uma intriga tão fatal que irá acabar em morte; Kazárin e Shprikh engrossam o caldo de mentiras, dissimulações e mesquinharias com o único intuito de obter algum ganho pessoal; o anti-herói Arbênin se encontra irremediavelmente preso a esta rede e, sem se dar conta, destrói a única chance de salvação que poderia ter.

O caráter especial da perspectiva de Liérmontov se apoia na consciência dos paradoxos inerentes ao próprio individualismo romântico, compostos pela tensão entre a visão de mundo individualista e a cultura russa que simultaneamente era fascinada e rechaçada por ela. O individualismo russo há muito era imaginado em termos estritamente privados. Na esfera pública, onde a reputação dos autores era conferida, a expressão dos valores coletivos sempre tendeu a suplantar a expressão pessoal. A sociedade cortês que Liérmontov habitava se estruturava de acordo com normas consensuais de sociabilidade harmônica que não só fragmentavam o 
individuo social, mas, também, impediam o exame da sua vida interior, sem falar na profundidade da psique como períodos mais recentes a conhecem. Esta separação profunda entre o público e o privado permaneceu mais ou menos constante na época de Liérmontov e ajuda a explicar a rejeição tradicional da cultura russa pela absoluta "individualidade da singularidade" do romantismo... "de encontro com aquela de unicidade" (que é característica do liberalismo iluminista). Como um individualista romântico, Liérmontov tomou para si a missão de examinar sua vida interior e a dos outros, expressando o que encontrasse publicamente. Se manifestamente ou implicitamente condenava a sociedade russa contemporânea às vidas sem o autoconhecimento que ela encorajava seus membros a levar, ele expressava seu desprezo não somente pela literatura, mas, também, através de flagrantes transgressões contra as normas reinantes de comportamento social. Tanto expressando suas emoções mais profundas como desmascarando a hipocrisia da sociedade; a missão de Liérmontov sempre envolveu fazer do privado público em um desafio direto à propriedade social. Este impulso na direção de expor a si e aos outros tornou Liérmontov maldito tanto para sua geração como para as gerações subsequentes de leitores russos. Porque Liérmontov se opunha implacavelmente à constrição individual em seu próprio tempo, há uma continuidade cultural, uma cumplicidade involuntária entre sua própria sociedade e aqueles que cunharam sua reputação posterior. ${ }^{23}$

Vem desta transgressão a surpresa e também a inação do príncipe quando Arbênin the recusa um duelo como parte de sua vingança. Apesar de proibidos, os duelos eram a melhor maneira de um homem ofendido defender a sua honra perante a sociedade, mas, ao invés de matar o príncipe enquanto dormia - o que

\footnotetext{
${ }^{23}$ Polwelstock, David: Becoming Mikhail Liérmontov: the ironies of romantic individualism in Nicholas l's Russia. Northwestern University Press, Evanston, Illinois, 2005, p. 07
} 
não encontra coragem para fazer - ou chama-lo para um duelo franco e honesto, Arbênin envolve o príncipe com uma anedota, o acusa de roubar no jogo e ao mesmo tempo recusa o duelo, privando-o da oportunidade de qualquer defesa e jogando a honra dele na lama, destruindo assim toda e qualquer possibilidade de êxito dentro daquela sociedade e suas regras de honra e conduta social.

PRÍNCIPE - Oh, onde está a minha honra? Devolva-me esta palavra e eu vou ficar em seus pés! ... Para você, não há nada sagrado! Você é um homem ou um demônio?

ARBIÉNIN. - Eu sou apenas um jogador.

PRÍNCIPE. - (Sentando-se, cobrindo o rosto com as mãos) Oh, minha honra, minha honra!

ARBIÉNIN. - A honra não voltará para você. A barreira entre o bem e o mal foi quebrada e todos vão Ihe virar a cabeça com desprezo; agora irá para o caminho dos renegados e entenderá a doçura das lágrimas de sangue e até a felicidade de seus entes queridos vai ser um fardo em sua alma; pensará apenas uma coisa dia e noite e aos poucos os sentimentos mais esplêndidos de amor se apagarão, até morrer a felicidade não vai dar sua arte; todos aqueles amigos barulhentos vão desaparecer como as folhas das árvores de um ramo podre e cobrindo o rosto e corando, passará pela multidão, Ihe 
entristecerá a vergonha mais que os crimes dos perversos. $E$ agora... (Saindo) Desejo-Ihe vida longa! (Sai).

O individualismo de Liérmontov ia contra toda e qualquer concepção de individualidade aceita na Rússia. Nenhum outro escritor no cânone russo foi tão duramente condenado e tão fastidiosamente mal interpretado. Nicolau I dizia que Liérmontov era moralmente corrupto, talvez até louco e, em qualquer um dos casos, um perigoso exemplo para os outros. Powelstock diz que "escrevendo do exílio, o Ocidentalista Aleksandr Herzen enalteceu Liérmontov como um homem talentoso cujo potencial revolucionário foi esmagado antes de brotar pela repressão autocrática. ${ }^{24}$ Sessenta anos depois, o teólogo, crítico literário e também poeta Vladímir Solovióv acusou Liérmontov de "demonismo" em uma palestra. Em resposta, o poeta e escritor Dmítri Merejkóvski glorificou Liérmontov como o profeta arquetípico do "futuro populismo religioso" russo.

A ideologia com certeza teve um papel determinante na recepção literária de Liérmontov. A discussão entre Solovióv e Merejkóvski veio de suas visões religiosas e morais diferentes. Ambos anteciparam a transformação da humanidade através de sua própria atividade de acordo com princípios divinos. ${ }^{25}$

Boris Pasternak, por sua vez, defendeu abertamente o íntimo entrelaçamento da persona do poeta com sua arte. O que Pasternak compreendeu foi o compromisso que Liérmontov tomou de coração aberto com sua visão poética pessoal. Para alguns, esta qualidade se traduz como uma enorme força carismática

\footnotetext{
${ }^{24}$ Polwelstock, David: Becoming Mikhail Liérmontov: the ironies of romantic individualism in Nicholas l's Russia. Northwestern University Press, Evanston, Illinois, 2005, p. 07

${ }^{25}$ Polwelstock, David: Becoming Mikhail Liérmontov: the ironies of romantic individualism in Nicholas l's Russia. Northwestern University Press, Evanston, Illinois, 2005, p. 08
} 
na poesia de Liérmontov. Belínski, crítico russo de tendências ocidentalistas que estava pessoalmente próximo de Liérmontov, sentia essa força como uma profunda e autêntica conexão entre o homem e a sua arte. Ele elogiava o "forte e profundo espírito" do poeta. O formalista Boris Eikhenbaum evitou explicitamente o uso de metáforas na descrição estilística, mas permitiu-se, no entanto, falar da "poderosa... hipnose emocional do discurso de Liérmontov."

Os pensadores russos do século XIX, Eslavófilos ou Ocidentalistas, estavam sempre engajados em polêmicas consagradas a respeito da identidade nacional e, invariavelmente caracterizavam Liérmontov como o mais "russo" ou como o mais "europeu" dos escritores russos, glorificando ou castigando-o de acordo com suas afinidades morais e seus pontos de vista éticos, estéticos, sociais ou até religiosos. Como veremos em seguida, esta discussão que permeia toda a história da literatura russa, veio mais tarde a influenciar as diferentes montagens que Meyerhold fez da peça ao longo das décadas de 20 e 30 do século XX.

A despeito da aversão russa ao individualismo romântico, o fascínio com Liérmontov perdurou por diversos motivos primeiro a realização artística da obra madura de Liérmontov simplesmente não podia, nem pode, ser ignorada, em segundo lugar o mito biográfico identificado por Nabókov - o aparente vaticínio do poeta sobre sua própria morte - joga uma irresistível aura de mistério sobre o autor. Nabókov tentou se distanciar do mito diferenciando-o dos méritos puramente artísticos de Liérmontov, mas sua fascinação é palpável.

\section{MITO BIOGRÁFICO OU FORÇA DO DESTINO?}


Liérmontov nasceu em 1814 quando Púchkin tinha quinze anos e morreu quatro anos depois da morte do grande poeta em 1837. Ou seja, com meros vinte e sete anos. Como Púchkin, caiu vitima de um duelo, mas em seu caso, não se tratou de uma sequência inevitável de tragédias que iam se sucedendo como se deu com Púchkin. O duelo que levou Liérmontov pertence antes àquele de tipo trivial tão em voga nos anos de 1830 e 1840, que serviu de mote, assim como o jogo, as máscaras e as intrigas fúteis daquela sociedade, para o drama Mascarada, ou seja, um tipo de duelo que "não raramente transformava ótimas amizades em assassinatos a sangue frio - um fenômeno antes de temperamento do que de ética. "26

A grande virada na carreira de Liérmontov veio alguns dias depois da morte de um dos maiores poetas russos, Aleksander Púchkin, em janeiro de 1837. Liérmontov que na época era um oficial de guarda de vinte e dois anos aspirante a poeta, respondeu imediatamente a noticia com uma lírica de cinquenta e seis linhas em razão do luto chamada "Morte do Poeta", ele acusava membros da aristocracia de perseguir Púchkin durante os últimos meses de sua vida e conspirar para instigálo ao duelo fatal. Em poucos dias, o poema de Liérmontov, circulando através de cópias feitas a mão, deixou em polvorosa toda Petersburgo. Aproveitando-se da súbita notoriedade, dias depois Liérmontov acrescentou uma coda venenosa e provocativa de dezesseis linhas ao poema onde nomeava diretamente membros da corte como "executores da Liberdade, do Gênio e da Glória" profetizando que se o Tsar não os punisse, o "Juiz Eterno" iria fazê-lo. Esta versão também teve ampla circulação. Liérmontov acabou preso e exilado pelo Tsar Nicolau I, sendo mandado para a frente de batalha no fronte caucasiano, onde o exército imperial se

\footnotetext{
${ }^{26}$ The Lermontov Mirage Author(s): Vladimir Nabokov Source: Russian Review, Vol. 1, No. 1 (Nov., 1941), pp. 31-39
} 
encontrava engajado em uma luta aparentemente sem fim para reprimir levantes locais repetindo, assim, o mito byroniano do herói romântico no exílio. Como ele, Pietchórin também foi exilado no Cáucaso, assim como alguns personagens condecorados de Mascarada presentes na mesa de jogo e no baile branco que quase um século depois Meyerhold irá usar para ressaltar sua crítica à sociedade da época. Menos de um mês passado da morte de Púchkin e o nome do antes obscuro poeta hussardo se tornou conhecido para qualquer intelectual ou amante das letras no império russo.

Já em seus primeiros escritos, Liérmontov expressou persistentemente dois anseios específicos: o primeiro de glória pessoal (slava) e uma ânsia de intimidade não somente com os objetos de sua afeição, mas, também, com seus leitores. $\mathrm{O}$ processo em dois estágios pelo qual Liérmontov escreveu "A Morte do Poeta" atesta seu desejo pela fama. Liérmontov acrescentou aquela coda decididamente mais assertiva só depois do sucesso encorajador da primeira versão e foi através da circulação dessa primeira versão que Liérmontov conquistou sua audiência. Ele agarrou a oportunidade de se definir mais acentuadamente aos olhos do leitor através de uma fala mais forte, de uma voz mais pessoal presente na coda. ${ }^{27}$

O episódio derradeiro da vida do poeta parece quase suicida. Existem abundantes evidências atestando que Liérmontov expressava os dois lados de sua personalidade na vida e na arte, tanto na esfera privada quanto em público, sugerindo que nenhum deles era mero exibicionismo. A própria obra de Liérmontov parece antever e até mesmo abraçar tal fim violento para sua vida, como atesta a novela "Princesinha Mary" em O Herói do Nosso Tempo, onde os protagonistas se batem em duelo por motivos fúteis, uma circunstância que domina o mito construído

\footnotetext{
${ }^{27}$ Polwelstock, David: Becoming Mikhail Liérmontov: the ironies of romantic individualism in Nicholas l's Russia. Northwestern University Press, Evanston, Illinois, 2005, p. 13
} 
em torno dele por sucessivas gerações. Como Vladímir Nabókov colocou, "Para o tipo emocional de leitor, muito da mordacidade e fascinação" de sua narrativa "reside no fato de que o próprio fim trágico de Liérmontov está de alguma maneira sobreposto" naquele de seus protagonistas e a projeção lírica de sua morte "adquire uma tensão adicional ao pathos quando o leitor percebe que o sonho do poeta se tornou realidade. ${ }^{, 28}$

Marc Slonin descreve a personalidade de Liérmontov como "excêntrica", destacando que era morbidamente sensível, tímido e agressivo, passional e sarcástico, sensual e idealista. ${ }^{29}$ Segundo ele, Liérmontov era dado a acessos de fúria, mas, por outro lado, tinha total e absoluto controle lógico de seus sentimentos e uma perfeita capacidade de dissimulação. Escondia a bondade de seu coração sob uma pesada máscara de ironia e desânimo.

Esta dupla característica da personalidade de Liérmontov já podia ser notada na infância, às vezes, tinha um temperamento incontrolável e irascível que exteriorizava de maneira extremamente cruel; outras, podia também ser alegre e até mesmo gentil. A incapacidade de se relacionar com os outros, tirando raras ocasiões continuou presente durante os poucos anos que passou na universidade, no serviço militar com os hussardos e até a sua morte em 1841. Seus personagens, como dito anteriormente, espelham facetas desta personalidade: Pietchórin podia ser extremamente cruel e egoísta, assim como Arbiénin, que irascível destruiu a vida de mais de um homem e assassinou a pura e inocente Nina; mas quando jovem era a alma de qualquer mesa de jogo, como atesta Kazárin no segundo ato de Mascarada, cena dois, aqui, como nos outros trechos citados, em tradução livre minha:

\footnotetext{
${ }^{28}$ The Liérmontov Mirage Author(s): Vladimir Nabokov Source: Russian Review, Vol. 1, No. 1 (Nov., 1941), pp. 31-39.

${ }^{29}$ Liérmontov: A Hero of His Time Author(s): i, Vol. 37, No. 4, Studies by Members of the SCMLA (Winter, 1977), pp. 158-161
} 
“KAZÁRIN:

(...) Lembro-me de nosso passado...

Quando juntos bebíamos na conta não consigo lembrar de quem

E éramos dois desmiolados.

Que tempos eram aqueles!

De manhã descansando com as lembranças agradáveis do dia anterior,

Depois o almoço, o vinho da adega do Raul,

A honra esculpida em taças brilhantes transbordando de espuma,

Conversas animadas de inteligência, e então o teatro...

A alma estremecendo pensando em como atrair as dançarinas ou atrizes.

É verdade que antes tudo era melhor e mais barato?

A peça acabava e corríamos para a casa de um amigo...

Entramos. ... o jogo está em seu pico,

Com os naipes, colunas de moedas de ouro,

Alguns ardem e outros empalidecem.

Sentamos e a batalha começa de novo e parece que a nossa alma está trespassada

De paixões e sentimentos incontroláveis e muitas vezes

Uma ideia gigante como a primavera

Levanta e se transforma em nossas mentes. 
...e se vencer o inimigo com suas habilidades,

Pode achar que o próprio Napoleão é patético e ridículo,

Porque você acredita ter o destino humildemente aos seus pés. "30

Liérmontov via em seus contemporâneos uma propensão para a falsidade e para a auto ilusão tanto na vida privada quanto publicamente. Os membros da sociedade aristocrática da qual fazia parte estavam sempre a iludir uns aos outros e, consequentemente, também a si mesmos. Em Mascarada, a baronesa tenta iludir o príncipe, o príncipe a Nina; Schprikh e Kazárin tentam tirar proveito da situação; Arbênin ilude ao príncipe roubando sua honra e, por fim é arrastado por toda esta rede de intrigas e ilusões e, a despeito de acreditar-se conhecedor de todas as

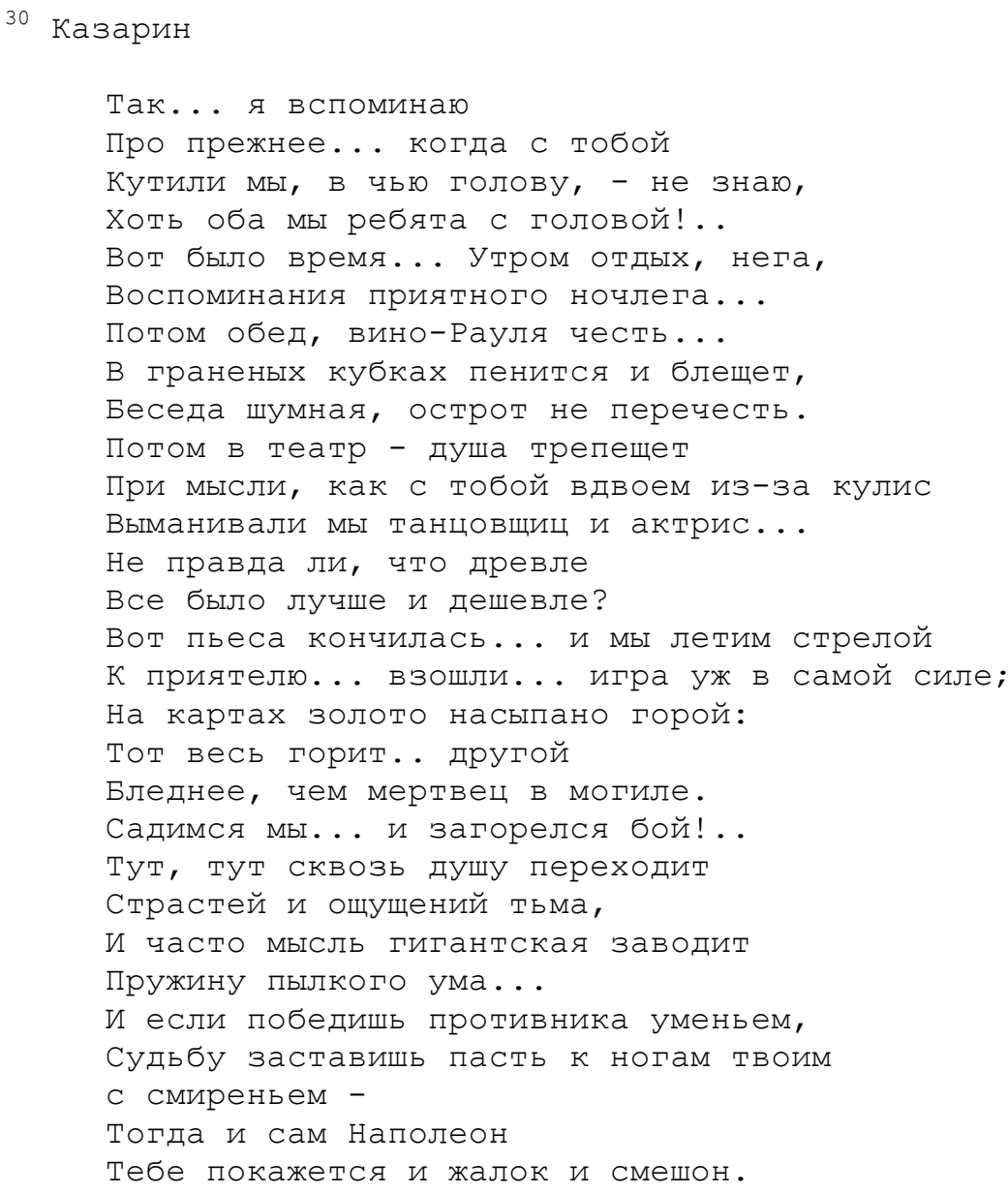


artimanhas e segredos, também é iludido pelo grande jogo do destino e, quando a venda sobre seus olhos cai, enlouquece diante do reconhecimento desta verdade maior e das consequências de sua auto ilusão. No mundo que Liérmontov concebia, os valores mais importantes eram a identidade individual, o autoconhecimento e toda e qualquer ação do individuo em completa conformidade com os próprios e mais genuínos desejos.

Para Vladimir Golstein, Mascarada revela uma abordagem bilateral para representar uma sociedade que transforma o conceito de "nosso tempo", do romance O Herói do Nosso Tempo, em algo real e tangível criando um cenário onde o protagonista, um homem independente e cheio de auto confiança, apesar de violento, torna-se um herói. Em outras palavras, o comportamento dos companheiros de Arbiénin - Kazárin, Schprikh, a baronesa e o príncipe - que só se ocupam com mentiras e manipulações secretas e a incapacidade de Arbiénin de questionar e modificar tais comportamentos é o que destaca o seu heroísmo, apanhado por esta rede de intrigas, termina por assassinar uma inocente e depois enlouquecer. Arbiénin representa ainda um importante paradoxo: enquanto rejeita com orgulho o mal que vê ao seu redor, ele permanece incapaz de discernir qualquer outra força no universo e, assim, termina por abraçá-lo. A peça, portanto, explora temas que continuariam centrais na obra de Liérmontov: de um lado o uso da máscara, a auto-obliteração e os males daí resultantes; do outro, o "julgamento pelo mal" do protagonista. ${ }^{31}$

Mascarada é testemunha da estreita conexão entre o pensamento de Liérmontov e a condição da sociedade contemporânea. Mesmo sua percepção dela sendo meio pessimista - "com tristeza eu olho para minha geração," declara o

\footnotetext{
${ }^{31}$ Golstein, Vladimir. Liérmontov's narratives of heroism. Northern University Press, 1998.
} 
orador do poema "Meditação" ("Duma"), de 1838 - ele não estava pronto para desistir dela, pelo menos não ainda. Como já foi dito, Mascarada revela uma abordagem bifurcada de Liérmontov com a representação da sociedade, incluindo vários personagens que personificam o conceito de "nosso tempo". Ele cria um pano de fundo independente onde as intrigas e manipulações deixam o protagonista livre para se tornar o herói, por mais falho e violento que seja. Arbiénin pode ver a onipresença do mal, de acordo com ele, o mundo é composto de jogadores implacáveis e suas vítimas.

“KAZÁRIN:

Ouça-me! Gosto de ti

E vamos falar sério.

Mas, faça-me um favor, irmão, deixe este aspecto

Horrível

E eu vou abrir para você

Todos os segredos da sabedoria humana.

Quer ouvir a minha opinião

Sobre a gratidão? Tenha um pouco de paciência.

Por mais que Voltaire e Descartes

Tentem explicar,

O mundo para mim é um jogo de cartas

E a vida é o banqueiro, o azar é um faro

E eu aplico ao mundo as regras do jogo.

Por exemplo, para explica-las agora

Imagine que eu jogue o As, 
Fiz isso por pressentimento,

Porque sou supersticioso com as cartas;

Suponha que por acaso e sem artifício,

Ele ganhe, eu estou muito feliz,

Mas não posso agradecer ao As

E continuar apostando até cansar

E depois, para concluir, cairá sob a mesa

Uma carta destruída. Mas você não me ouviu, meu querido."32

\section{ARBIÉNIN:}

(Pensativo)

Reina em todos os lugares o mal e a ilusão.

E ontem, como um tolo,

Eu ouvia em silêncio, como aconteceu! $!^{33}$

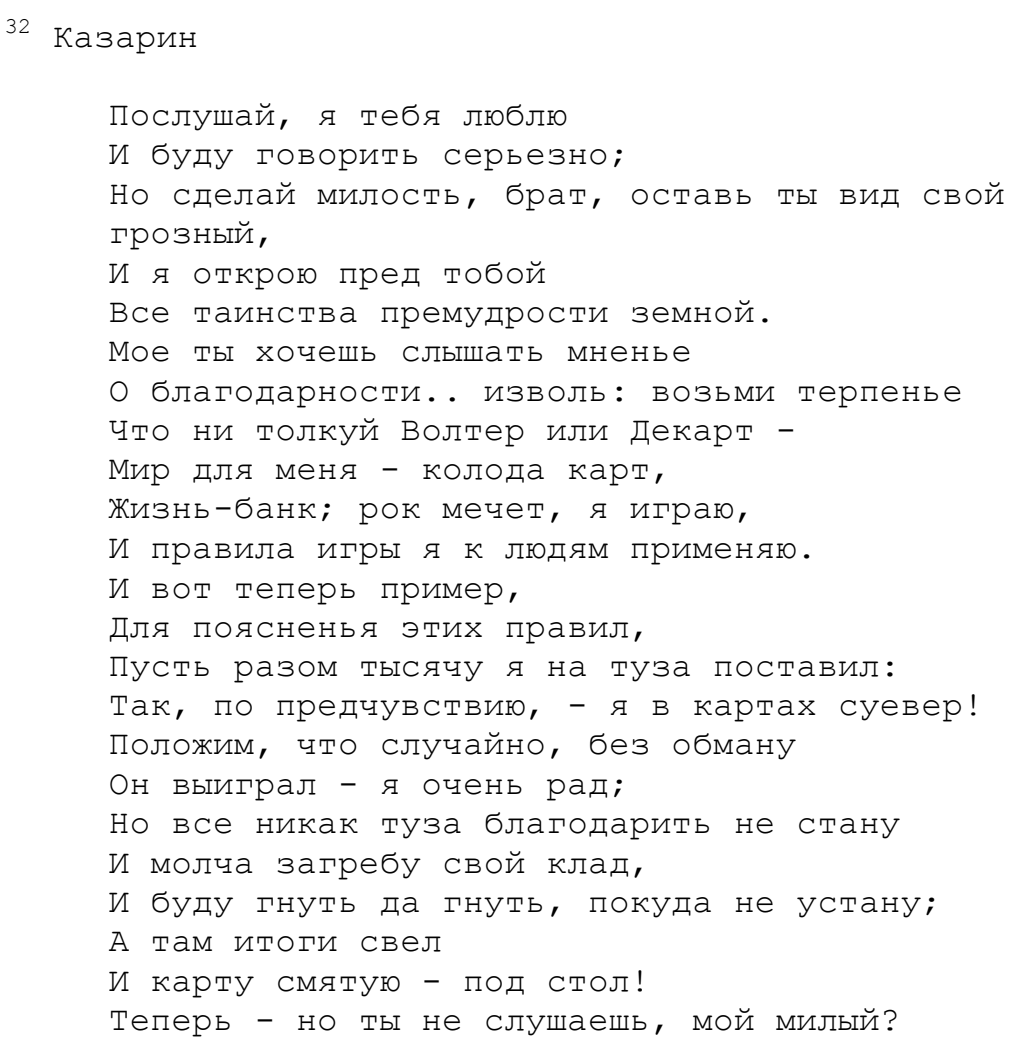


(..)

ARBIÉNIN:

Oh! Quem vai me dar de volta àquelas esperanças tempestuosas,

Quem me daria de volta àqueles dias insuportáveis e ardentes!

Por aqueles dias, eu daria a minha alegria ignorante e tranquila,

Mas não para mim...

Por acaso fui feito para ser marido ou pai de família?

Eu, eu, eu provei

Todas as fraquezas, os vícios e os males

E diante do seu rosto nunca tremi?

Fora meu anjo benfeitor! Eu não conheço você.

Fui enganado e hoje

Nossa breve união está quebrada, destruída.

Adeus, adeus...

(Deixa-se cair em uma cadeira e cobre o rosto com as mãos). ${ }^{34}$

33 Арбенин

(в размышлении)

Повсюду зло - везде обман,

И я намедни, я, как истукан,

Безмолвно слушал, как все это было!

34 Арбенин

O! кто мне возвратит... вас, буйные надежды,

Вас, нестерпимые, но пламенные дни!

За вас отдам я счастье невежды,

Беспечность и покой - не для меня они!..

Мне ль быть супругом и отцом семейства,

Мне ль, мне ль, который испытал

Все сладости порока и злодейства,

И перед их лицом ни разу не дрожал?

Прочь, добродетель: я тебя не знаю, 
Arbiénin tenta abrir seu caminho através deste cenário recusando-se a escolher um lado. Da mesma forma, Pietchórin procura um meio termo entre mestre e escravo, enquanto o Demônio navega entre os estremos da rebelião e da entrega. Tal busca por um meio termo aponta para uma relevância inequívoca do pensamento de Liérmontov; a articulação desse meio termo de conduta é ainda mais importante numa cultura em que a paixão pelos extremos é quase proverbial.

Junto com esta decepção com a conduta heroica, Liérmontov também ataca o comportamento que é flagrantemente não heroico, ou seja, fraco, impessoal ou irresponsável. Liérmontov escrevia em uma época de medo quase universal, falsidade e autonegação, ocasionado pela repressão pós- decembrista e o subsequente trauma social que ela ocasionou. Neste primeiro grande trabalho completo, o drama Mascarada (1835), Liérmontov põe em contraste um independente e poderoso indivíduo, Arbiénin, a sua sociedade, ou seja, um grupo de não indivíduos que ostenta suas máscaras socialmente aceitas e são incapazes de expressar, quem diga defender, suas personalidades e seu direito de desenvolvêlas.

É importante ressaltar que Liérmontov não é dominado por seus heróis, ele somente foca sua atenção neles. O drama é o espaço onde o poeta experimenta diversas máscaras, comportamentos e seus diferentes resultados. Parece não haver absolutos na perspectiva de Liérmontov exceto, talvez, o valor do verso poético. Assim, cada comportamento, cada sistema de valores, se torna objeto de exploração e reavaliação. Mais tarde, o grande diretor Vsévolod Meyerhold vai, também com

Я был обманут и тобой,

И краткий наш союз отныне разрываю -

Прощай - прощай!..

(Падает на стул и закрывает лицо.) 
Mascarada, consolidar seu teatro de máscaras e abrir caminho para toda uma revolução estética e conceitual no teatro russo.

Desapontado com a recepção de Mascarada e a impossibilidade de vê-la encenada, Liérmontov não voltou mais ao drama. Mesmo assim, seu aprendizado com o teatro, onde escreveu cinco peças, foi uma enorme escola que possibilitou que dominasse a arte desafiadora de criar várias personagens diferentes e toda a complexidade de suas relações e interações em textos artísticos longos como o Demônio e O Herói do nosso Tempo. ${ }^{35}$

Como vimos, a criação romântica reconhecia o lado problemático da relação entre autor e leitor que ajudou a desenvolver. Seus praticantes, Byron e Púchkin, por exemplo, sentiam a pressão crescente exercida sobre eles pelos heróis românticos para que "fossem eles mesmos" ou seja, personificar algum dos tantos heróis românticos que habitavam seus textos. Eles reproduziam imagens do autor no texto somente para torná-las sem efeito ou substituí-las com imagens concorrentes. Fragmentavam a si mesmos de propósito para escapar das tentativas do leitor de finalizar a imagem que formavam. Tais autores, de alguma forma, acabavam por se esconder atrás das obras, deixando para trás somente um lúdico, ilusório e auto contraditório alterego.

Púchkin e Byron se divertiam ao brincar com as expectativas do leitor em seus textos, por outro lado, a insistência de Liérmontov em reafirmar sua personalidade como uma unidade levou-o rejeitar esta instância lúdica. Enquanto a tensão entre a perspectiva autoral (privada) e do leitor (pública) já era inerente à criação romântica, o etos radicalmente individualista de Liérmontov elevou-a ao nível

\footnotetext{
${ }^{35}$ Golstein, Vladimir - Liérmontov's Narratives of Heroism, Northern University Press, 1998. p. 54.
} 
máximo. Para ele, o impasse entre autor e leitor não era um jogo, mas um duelo por sua própria existência, uma metáfora que assustadoramente evoca o intenso confronto do individualismo absoluto de Liérmontov. Arbênin, ao encontrar o príncipe dormindo, desiste de matá-lo e, antes de deixar um bilhete convidando Zvézditch para o jogo, termina o monólogo com as seguintes palavras:

“(...) Ele viverá, o assassinato já não está mais em voga.

Aos assassinos castigam em praça pública.

Não nasci no seio de um povo instruído?

O idioma e o ouro são nosso punhal e nosso veneno. "36

Tal intensidade explica porque Liérmontov não era apenas consciente, mas hiperconsciente da noção de interpretação do leitor e porque se recusava a recuar. Isso seria desonesto e desprovido de honra.

A identidade ética e social radicalmente individualista de Liérmontov, contudo, rejeitava qualquer modelo socialmente definido de si mesmo e não permitiria o recuo ou a fragmentação de si nem como instrumento literário. Liérmontov insistiu em deixar registrado em sua obra uma personalidade arquetípica que mantinha uma continuidade palpável não somente entre si mesma e sua persona, mas, também, entre sucessivas realizações autorais. Pietchórin, Arbiénin, Vadin, o Demonio... Seus heróis ou anti-heróis, são constantemente parecidos e, como explica o prefácio do autor em O Herói do Nosso Tempo, frequentemente

\footnotetext{
36 так, так, он будет жить, убийство уж не в моде.

Убийц на площадях казнят.

Так!. в образованном я родился народе?

язык и золото... вот наш кинжал и яд!

(Берет чернил и записку пишет-берет шляпу)
} 
confundidos com o próprio Liérmontov, quer isso fosse proposital ou não. Liérmontov certamente usava máscaras, mas ao contrario de Púchkin, ele não estava disposto a deixar que a máscara substituísse o homem, nem mesmo temporariamente. No ato da escrita, Liérmontov, mesmo no seu tom mais irônico, tinha que sempre e em toda parte continuar Liérmontov.

Liérmontov, como vemos, está ciente das consequências potencialmente trágicas da cega autoafirmação. Ao contrario dos iluministas, ele abraça a complexa e contraditória posição do individuo romântico diante de um destino trágico. Todos os protagonistas de Liérmontov manifestam um individualismo radical e uma atitude antagônica com o mundo e seu Criador. Seja no paraíso, num monastério ou na sociedade aristocrática, eles percebem a si mesmos como prisioneiros e são atormentados pelo sentimento de perda: do amor, da honra, da terra natal ou do paraíso. Tanto a alma que definha e se consome por causa da perda da música dos céus no poema "O Anjo," quanto o demônio atormentado pela lembrança de dias melhores, sofrem a mesma aflição: a experiência do "paraíso perdido" ou seja, simultaneamente o êxtase e a perda. A ansiedade e o pessimismo parecem ser uma característica permanente nos heróis liermontovianos, Arbiénin, por exemplo, anseia por amor, apesar de casado Ihe é difícil acreditar que uma alma tão pura como Nina possa amá-lo. Esta ansiedade por fim leva-o ao ciúme, à vingança fútil ao assassinato, à perda do amor, da razão e de toda e qualquer possibilidade de salvação. Mesmo assim, Liérmontov articula um verdadeiro insight ao demonstrar como a mesma perspectiva intelectual pode produzir resultados tão drasticamente diferentes em personalidades distintas. Para Liérmontov, a perspectiva filosófica tem menos influência nas ações de cada um do que seus traços de personalidade. Tal indiferença pela perspectiva ideológica ou filosófica explica em parte o desdenho do 
poeta pela discussão metafísica em Mascarada. As reações diante da perda variam drasticamente de um herói para outro, é a sensibilidade artística de cada um que parece ser a chave para definir sua conduta pessoal. Uma personalidade criativa media essa perda através da arte ou da música; uma personalidade sem criatividade não dá frutos, só rebeldia e destruição. Os que não têm habilidade para transcender suas ansiedades, tensões e o vácuo de sua existência pela arte, recorrem a competições sem sentido ou conquistas amorosas.

Seguindo as inclinações byronianas em voga na época tanto quanto sua própria disposição, Liérmontov se divertia ofendendo aos outros, mas ainda assim, não se pode de maneira alguma afirmar que este ânimo inoportuno estivesse no cerne de sua personalidade ao invés de ser apenas uma couraça embrutecida pelo tempo, nem que, em muitos casos, sua atitude não fosse aquela de um jovem um tanto infantil, morbidamente consciente de si mesmo, mas de coração puro, que erguia diante de si uma barreira à prova de sentimentos. Chistes que muitas vezes ele emprestou a seus personagens: Pietchórin tem muito disso ao longo de O Herói do Nosso Tempo e podemos ver a mesma disposição no passado de Arbiénin, em sua ira e implacável sede de vingança e em seu humor saturnino, o que não quer dizer que não pudesse ser também amoroso com Nina. No final do primeiro ato, logo que ela chega da Mascarada, Arbiénin abre seu coração num belíssimo monólogo onde toda esta disposição romântica aparece brilhantemente sintetizada:

\author{
ARBIÉNIN: \\ Ouça... o destino nos uniu para sempre \\ Nem você nem eu podemos julgar \\ Se é um erro, talvez.
}


(Puxando-a, trata de sentá-la em seu colo e beijá-la).

Você jovem de corpo e alma.

Do enorme livro da vida,

Você leu somente a capa e, diante de ti

Se encontra um mar de felicidade e maldade.

Anda por qualquer caminho cheia de sonhos e esperanças.

Mas adiante tudo te espera.

O passado de sua vida é uma página em branco.

Sem conhecer seu coração nem o meu,

Você se entregou e me ama; eu acredito.

Eu amo de outra maneira; já vi tudo,

Adivinhei tudo e tudo compreendi e conheci.

Amei com frequência, mas, frequentemente, também odiei

E, mais que tudo, sofri.

A princípio tudo desejei, então desprezei;

Às vezes eu mesmo não me entendo,

Por outras, o mundo a mim.

Na minha vida vi as pegadas da maldição

E friamente fechei o caminho

Para minha felicidade sobre a terra...

Assim se passaram muitos anos.

Aqueles dias envenenados de inquietude

Da minha juventude cheia de vícios,

Com que profunda repugnância os recordo agora

Recostado sobre seu peito! 
Antes, desgraçadamente, não conhecia o valor

Que você tinha para mim.

Mas, por sorte, esta casca grossa

Logo foi caindo de minha alma e o mundo

Novamente se revelou diante de meus olhos,

Sem dúvida esplêndido,

E eu renasci para a vida e para o bem.

Mas você sabe, às vezes não sei que espírito maligno

Me atrai à tempestade dos dias passados

E apaga da minha memória

Seus olhos claros e sua voz milagrosa.

Em luta comigo mesmo, sob o peso de dolorosos pensamentos,

Me volto calado, severo e sombrio;

Às vezes temo manchar-te com minhas mãos;

Temo que te assuste um gemido,

O som de um tormento

E então me diz que não te amo. ${ }^{37}$

\footnotetext{
37 Арбенин

Послушай... нас одной судьбы оковы

Связали навсегда... ошибкой, может быть;

Не мне и не тебе судить.

(Привлекает к себе на колени и целует.)

Ты молода летами и душою,

В огромной книге жизни ты прочла

Один заглавный лист, и пред тобою

Открыто море счастия и зла.

Иди любой дорогой.

Надейся и мечтай - вдали надежды много,

А в прошлом жизнь твоя бела!

Ни сердца своего, ни моего не зная,

Ты отдалася мне - и любишь, верю я,

Но безотчетно, чувствами играя,
} 
NINA:

(olhando carinhosamente acaricia a cabeça dele).

Você é um homem estranho.

Quando me fala com tanta eloquência de seu amor,

Sua cabeça arde e suas ideias brilham nos olhos,

Então eu acredito facilmente em tudo;

Mas, às vezes... com frequência..."38

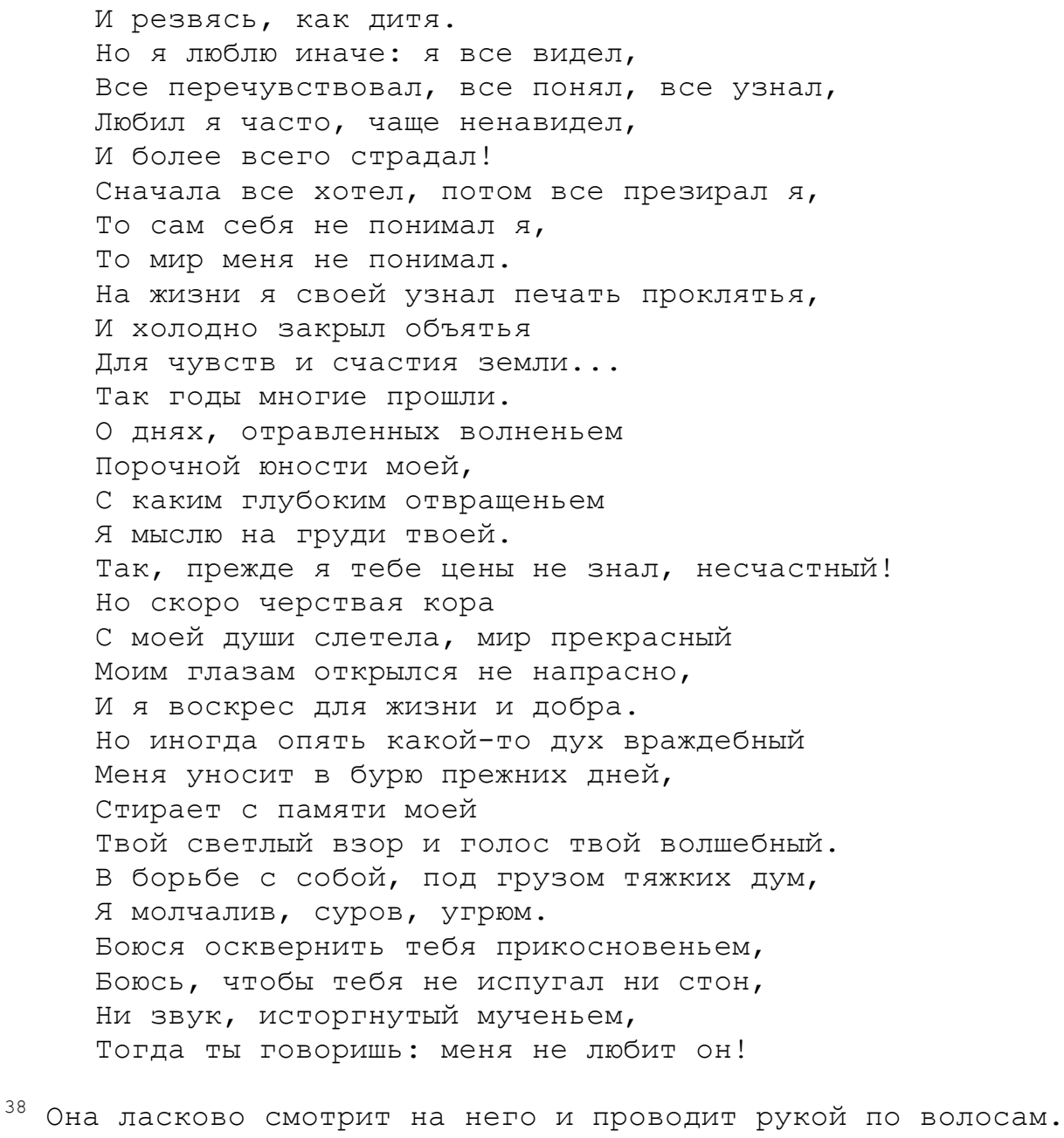

Нина

Ты странный человек!.. когда красноречиво

Ты про любовь свою рассказываешь мне,

И голова твоя в огне,

И мысль твоя в глазах сияет живо,

Тогда всему я верю без труда; 
A verdade é que quando um romântico frustrado e sem raízes se volta para a vida real, ele o faz para desacreditá-la ou para vingar-se dela revelando-a em toda sua feiura, vulgaridade e maldade. Janko Lavrin afirma que "quanto mais forte for o seu temperamento romântico, mais forte e incisivo será o realismo de suas acusações.

O isolamento que Liérmontov experimentava neste mundo cheio de intrigas, falsidade e opressão não era somente social, mas de um tipo quase cósmico. Era como se o jovem sensível tivesse sido arrancado de outro mundo idealizado e jogado neste contra a vontade por algum erro do destino. Por isso mesmo seu humor era sempre tão melancólico. Um romântico com tais características certamente esperava mais da vida do que esta podia lhe dar e, tendo suas expectativas frustradas, não podia evitar que seus melhores sentimentos se transformassem em seu oposto: a bondade inata em egoísmo embrutecido e cheio de rancor, o amor profundo assumindo a máscara da mais frívola indiferença. Um idealista assim desapontado tende a virar um cínico.

Quando se tornou um famoso poeta e as mulheres passaram a procurar e requisitar sua atenção e companhia, Liérmontov, assim como o príncipe e Arbiénin quando jovem, passou a seduzi-las calculadamente e a sangue frio pelo simples prazer de poder fazê-lo. Dois trechos em Mascarada exemplificam bem este comportamento tão em voga na época. Na segunda cena do segundo ato, Kazárin, tentando convencer Arbiénin a voltar para o submundo do jogo tece tais comentários sobre a natureza humana, a honra e as mulheres:

Но часто

\footnotetext{
${ }^{39}$ Some Notes on Liérmontov's Romanticism Author(s): Janko Lavrin Source: The Slavonic and East European Review, Vol. 36, No. 86 (Dec., 1957), pp. 69-80
} 
KAZÁRIN:

(A parte)

Pensativo.

(Para Arbiénin)

Passemos agora

a um outro caso e vamos analisar aos poucos

Para evitar confusão.

Suponha, por exemplo, você queira novamente abandonar o jogo

Ou a libertinagem

E seu amigo diga:

"Ei, irmão, cuidado!",

E Ihe dê outros sábios conselhos;

Você ouviria e Ihe desejaria

Boa noite e muitos anos felizes.

E se tentar curá-lo de sua dependência do vinho,

Você deve imediatamente embebedá-lo

E como quanto aos naipes, ganhe logo uma partida

Em troca do conselho se você se salvar no jogo, tem que ir a um baile

E se apaixonar por sua mulher e, se não se apaixonar,

Pelo menos conquistá-la para se vingar do marido.

Em ambos os casos, você estaria certo, companheiro, 
Você vai trocar o conselho por uma lição. ${ }^{40}$

\section{ARBIÉNIN:}

Você é um moralista notável.

Todo mundo te conhece...

Mas, quanto ao príncipe, eu vou pagar a lição com a minha honra. $^{41}$

\section{KAZÁRIN:}

(Ignorando suas palavras)

O último ponto que devo esclarecer.

Você ama uma mulher... dá em sacrifício a sua honra,

40 Казарин

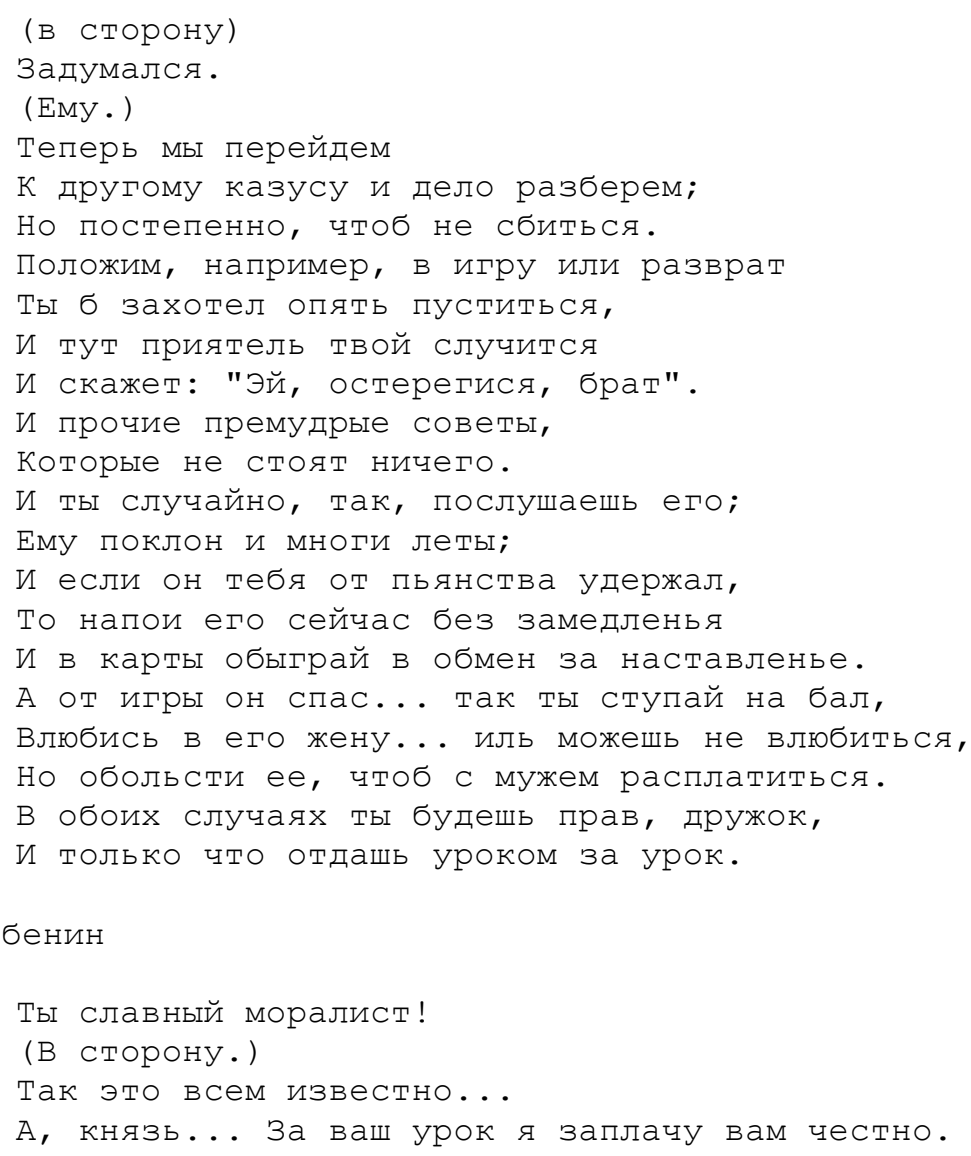


A sua riqueza, sua amizade e talvez sua vida,

A cobre de honras e de diversão,

Mas, por que você deve ser grato a ela?

Você terá feito tudo isso não por paixão,

Mas, em parte por causa do orgulho, para possuí-la,

Você sacrifica a si mesmo, mas não para a sua felicidade.

Sim! Pense friamente

E me dirá que tudo no mundo é convencional. ${ }^{42}$

\section{ARBIÉNIN:}

(Desgostoso)

Sim, sim, você está certo, o que é o amor para as mulheres?

Elas sempre precisam de novas vitórias e,

Talvez, preces, lágrimas e tormentos

E vai lhe parecer ridículo este aspecto e essa voz suplicante.

Você está certo: é tolo aquele que acredita que sonha

Em encontrar em uma única mulher o paraíso terreno. ${ }^{43}$

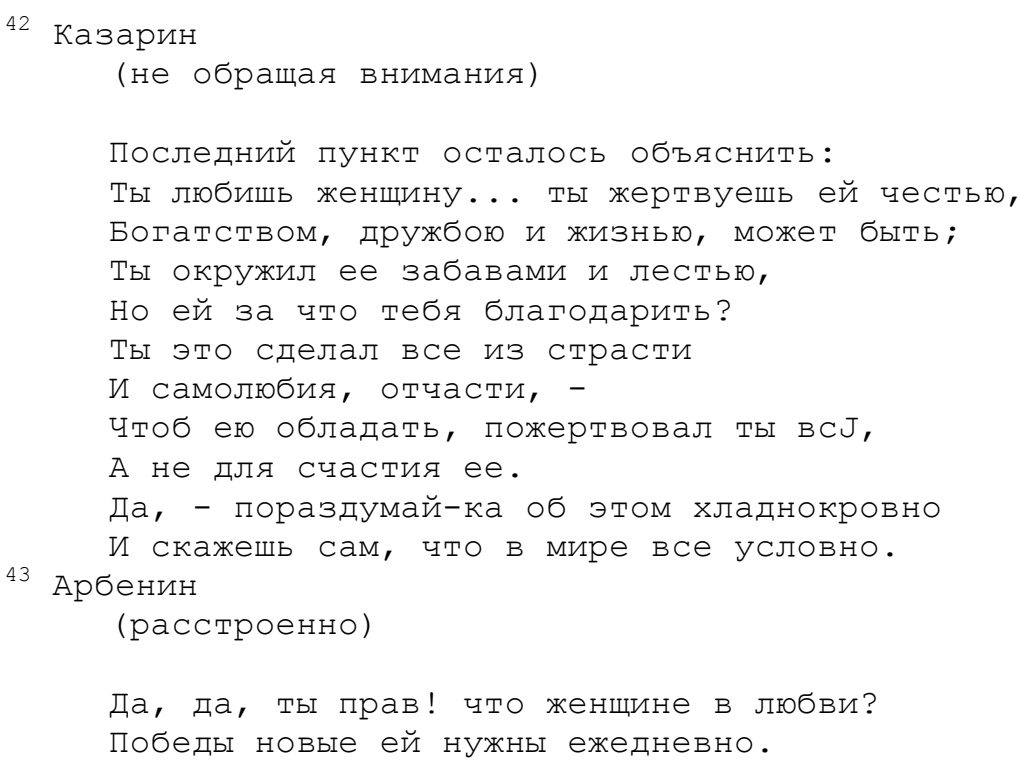


No outro trecho, cena quatro do segundo ato, logo quando chega para o jogo de cartas que arruinará sua vida, o príncipe comenta a parte:

"Seguindo as regras da sociedade, ao marido eu concedo, e à mulher arrasto a asa ...

A fim de ganhar lá, - aqui eu posso perder!

(Senta-se)., ${ }^{, 44}$

Liérmontov também mostrava a disposição de um caçador profissional, cansava-se e tornava-se indiferente assim que a conquista terminava. ${ }^{45}$ Apesar disso, Liérmontov foi um dos maiores e mais influentes poetas russos do século XIX, sendo capaz de exprimir em versos ou prosa a angústia que a mordaça imposta por Nicolau I à intelectualidade que impossibilitada de agir e, ao mesmo tempo, com a paz de espírito agitada pela inação procurava na rebeldia um modo de suprir essa carência. Assim como Pietchórin, símbolo maior na literatura russa da inquietude e da busca permanente pela tempestade como condição de sobrevivência, esta elite intelectual foi de encontro a uma morte violenta. Não é à toa que Liérmontov

Пожалуй, плачь, терзайся и моли -

Смешон ей вид и голос твой плачевный,

Ты прав - глупец, кто в женщине одной

Мечтал найти свой рай земной.

${ }^{44}$ Князь

По светским правилам, я мужу угождаю,

А за женою волочусь...

Лишь выиграть бы там, - а здесь пусть проиграю!.

( Садится . )

${ }^{45}$ Liérmontov: A Hero of His Time Author(s): Rochelle H. Ross Source: The South Central

Bulletin, Vol. 37, No. 4, Studies by Members of the SCMLA (Winter, 1977), pp. 158-161 
continua a desconcertar seus leitores e admiradores até hoje. Quanto mais aprendemos sobre ele, mais complexos se tornam sua poesia e sua personalidade.

A tensão social, cultural e literária entre Liérmontov e seus leitores sempre foi um caminho de duas mãos. Quanto mais resistiam ao individualismo de Liérmontov, mais ele - mesmo quando queria conquistá-los - se opunha a esta resistência, afirmando publicamente e com vigor, o valor, a autonomia e a clareza de sua visão pessoal. O radicalismo de seu individualismo romântico transmitia esta ambivalência em relação aos leitores russos e, essa atitude paradoxal exerceu um papel sem tamanho na cristalização de suas práticas literárias e em seu comportamento diante da vida. Ao inflar e escancarar a sua realidade problemática diante de seus leitores, Liérmontov incorporou na sua vida e obra o enigma que iria saudar muitas gerações ainda por vir.

Dada a oposição ao individualismo na Rússia, a obra de Liérmontov ainda hoje parece desafiar aqueles que a leem. O poeta incorporou este antagonismo propositalmente em sua obra, principalmente, nos trabalhos mais importantes e que, por essa razão, continuam resistindo até às mais obstinadas tentativas de interpretação equivocadas, nos termos do vocabulário moral e político russo prevalecente até pouco tempo atrás. Quando lidos dentro de tais moldes, sejam eles políticos, sociais, religiosos ou culturais, os textos revelam apenas contradições, ambivalência moral e uma ironia insondável.

É possível notar que as confusões e o silêncio em relação ao abrangente propósito autoral de Liérmontov e seu significado nascem de uma resistência cultural particularmente russa ao individualismo romântico, reação que é mais antiga e mais profunda do que aquela trazida pelas ideologias políticas soviéticas e suas amarras institucionais. De certa forma, aqueles que no século XIX avaliaram Liérmontov em 
termos morais ou religiosos extremos - como, por exemplo, Vladímir Solovióv ou Dmítri Merejkóvski - entenderam melhor o individualismo romântico que dava forma a sua proposta literária do que os críticos da época soviética. Eles estavam de alguma forma entre aqueles próximos do poeta e implicitamente reconheciam - e rejeitavam - o modelo radical de indivíduo que Liérmontov propunha e sua oposição tanto à noção do primeiro de sujeito imperial, quanto à ideia do segundo de um individuo humano mediado pela humildade divina. Merejkóvski, por outro lado, não só reconhecia como sinceramente endossava a individualidade radical de Liérmontov.

Foi em resposta a este conflito entre os valores libertários do romantismo e a repressão esmagadora, encenado como uma batalha até a morte entre as normas culturais vigentes e o etos radical do individualismo romântico que Liérmontov desenvolveu sua poética madura. Liérmontov defendia um comportamento baseado em escolhas individuais, ao mesmo tempo insistindo que tais escolhas deviam ser feitas sobre os fundamentos dos princípios internos de consciência e integridade. Quando Liérmontov surgiu para a ocasião e forneceu uma resposta poética brilhante e imediata à trágica perda para a Rússia de Aleksandr Púchkin ("A Morte do Poeta", 1837), ele respondeu também à necessidade urgente de sua época de heróis que incorporassem e celebrassem os valores do individualismo. Assim, ele foi não só o maior poeta romântico da Rússia, ou o pai de sua prosa psicológica, mas, também, um consistente e corajoso promotor e defensor da doutrina que, para melhor ou para pior, define a própria modernidade. 


\section{MEYERHOLD E GOLOVIN NOS TEATROS IMPERIAIS}

O Aleksandrínski em São Petersburgo era um teatro enorme, um ninho de burocratas pretensiosos e empertigados devotados aos gostos da família real e seus dignitários. Ali atuava uma plêiade de atores de índole oitocentista, virtuosos acostumados ao estilo "canastrão" de representar, que frequentemente se recusavam a decorar o texto e não estavam nem um pouco dispostos a tolerar a hegemonia desta figura recém-surgida na história do teatro, o encenador.

Conta Ripelino, que no início do século, o ministro da casa real, barão Frederiks, amante de cavalos, colocou na administração dos cinco teatros imperiais de Moscou e São Petersburgo o camarista da corte de Sua Majestade, Vladímir Teliakóvski, somente por ter sido oficial da guarda montada. ${ }^{46}$ Teliakóvski, no entanto, mostrou-se surpreendentemente perspicaz e até brilhante, como quando chamou Meyerhold para o cargo de ator dramático e diretor de prosa e ópera do Marlínski e do Aleksandrínski. O que, no entanto, não significa que tivesse pronto a se livrar dos velhos hábitos dos teatros imperiais, mas, também não era de recusar reformas, contanto que moderadas.

Meyerhold foi para lá por indicação do cenógrafo Aleksandr Golovin, que acompanhava com interesse sua atividade como encenador na companhia teatral da Komissarjévskaia nos quatro anos anteriores. O fato de Teliakóvski ter aceitado aponta para um desejo de renovar o velho mundo embolorado e quando os críticos bradaram "escândalo!", declarou impassível que contratara Meyerhold exatamente porque corriam a seu respeito os piores comentários possíveis e acrescentou que se um artista é alvo de tanta aversão, deve ter algum valor.

\footnotetext{
${ }^{46}$ Ripelino, Angelo Maria. O Truque e a Alma. Perspectiva, São Paulo, 1996, p. 127.
} 
Golovin estava no Aleksandrínski desde 1902, mas ainda não tinha tido a oportunidade de soltar sua criatividade. Não poderia haver união mais promissora e mutuamente enriquecedora: Meyerhold dava muita importância à pintura no teatro, o que correspondia às aspirações de Golovin perfeitamente; e as cores e fantasias de Golovin com frequência influenciavam a criatividade de Meyerhold. Juntos, como veremos, eles uniram o palco e o auditório com ajuda da arquitetura, da cenografia e da atmosfera, além de trazer os atores para o proscênio e cercá-los de cenários suntuosos. Formado em pintura, Golovin iniciou os estudos como arquiteto e chegou a trabalhar com design de móveis e decoração de interiores até se mudar para São Petersburgo em 1901 e começar a trabalhar como cenógrafo combinando simbolismo e modernismo, o que muito agradou Meyerhold, assim como Diáguilev e Stalinslávski, com quem também chegou a trabalhar.

Foi neste teatro retrógrado onde precisava vencer a aversão dos conservadores e os virtuosismos individuais que Meyerhold começou a desenvolver suas próprias ideias inovadoras. O que não era tarefa fácil. Para acalmar os ânimos dos veteranos firmou um compromisso com os conservadores, por mais incoerente que isto pudesse parecer, de que diretor e cenógrafo somente usariam recursos modernos para redescobrir os encantos dos tempos passados e explicou em uma carta à revista Zolotóe Runó (O Velo de Ouro) que dali em diante se desdobraria em duas figuras distintas, o pesquisador de novas experimentações e o diretor das cenas imperiais. "Enquanto viverem os grandes atores do século passado, afirma em essência Meyerhold, o teatro em que eles atuam deve tirar seu alimento deles. Mas, ao lado destes admiráveis intérpretes, no palco também há lugar para o cenógrafo e o diretor." 47

\footnotetext{
${ }^{47}$ Ripelino, Angelo Maria. O Truque e a Alma. Perspectiva, São Paulo, 1996, p. 128
} 
"Uma fratura completa. Não seria esse um grande crime contra as antigas tradições, cujo gracioso declínio deve ser cuidadosamente acolhido...

'É assim que vejo: Assim como precisamos de quadros, galerias e museus, também precisamos do teatro de estilo imperial e seus atores veteranos, os portadores das tradições (...). Se os cenários vulgares, com suas decorações e paredes ingenuamente pintadas como na velha escola e que tão frequentemente funcionaram para peças de Ostróvski, Griboiédov e Gógol, fossem substituídos pelas criações de um verdadeiro mestre, harmonizadas com a decoração dourada da casa de espetáculos, com o rico veludo de suas poltronas e camarotes e, acima de tudo, com os ecos da atuação clássica... Então o grande Teatro iria brilhar com novas cores..."148

Desta proposta derivou o "tradicionalismo" de Meyerhold, que reinventava a cada nova montagem a atmosfera e as estruturas do tempo em que o autor da obra vivera, usando recursos modernos para redescobrir o encantamento dos tempos passados. Um motivo comum nas peças da época até a revolução de outubro.

Entretanto, para sua estreia em 30 de agosto de 1908 escolheu um drama moderno, As Portas do Reino de Knut Hamsun. O que obviamente não agradou aos atores que, para provocá-lo assim como faziam com Golovin, a quem não

\footnotetext{
${ }^{48}$ Rudnitsky, Konstantin - Russian and Soviet Thatre, tradition and avant-garde, Thames and Hudson, 1989.
} 
suportavam, atuaram mal e a peça foi um fracasso.

Para que tal "tradicionalismo" desse certo era fundamental que o cenário estivesse de acordo com o método de atuação e que este sustentasse o projeto cenográfico e fosse sua razão de ser. Meyerhold descreveu o sistema na revista $O$ Amor a Três Laranjas:

"Há toda uma série de axiomas obrigatórios para todo e qualquer ator, não importa o teatro em que ele crie. Do processo de estudo dos teatros antigos é preciso dizer: isso é uma espécie de acummuler des trésors - não para fazer ostentação dos valores obtidos, tais quais eles são, mas para (tendo aprendido a mantê-los e conservá-los)... aspirar a subir 'inspirado' ao palco e saber começar uma vida à moda do teatro no palco: fazer uma reverência com um gorrinho miserável, como se ele estivesse estrelado de pérolas, atirar sobre os ombros uma capa furada com um gesto de fidalgo... O que significa, na nossa compreensão, trasladar o tradicional do passado para o presente? A repetição de algo que um dia existiu não é o que procuramos (a simples repetição é tarefa do Teatro Staríni). A diferença no trabalho de reconstrução e nas tarefas da livre construção da nova cena dá-se à base do estudo e da escolha do tradicional. ${ }^{, 49}$

Em 9 de novembro de 1910 Meyerhold estreou Don Juan e fez o possível para

\footnotetext{
${ }^{49}$ Liubok k triom apelsínam, 1914, n 4-5, pp. 96-98 [in. Teatro Russo, p. 55]
} 
reconduzir a comédia de Molière, contaminada pelas formas de atuação do teatro francês do século XVII, de volta ao clima das representações na corte de Luís XIV em Versalhes com sua futilidade dançante, os falsos dourados e o brilho do grand siècle; segundo o diretor, uma época onde "o teatro tintina dos guizos da pura teatralidade." 50

Pela primeira vez no Aleksandrínski o espaço cênico foi harmonizado com a arquitetura do teatro, com um projeto pictórico que envolvia até mesmo o revestimento das poltronas, Golovin conseguiu unir as severas estruturas do teatro à época representada e todo seu fausto, o que suavizou a separação entre o palco e a plateia, transformando o Aleksandrínski em algo que lembrava um conjunto de salas deslumbrantes, como aquelas da Versalhes de Luís XIV. Como faria mais tarde em Mascarada, Meyerhold relegou a pintura ao fundo, em painéis que representavam o lugar da ação.

Se para Don Juan a inspiração tradicionalista foi à corte de Luís XIV, para Orfeu e Eurídice foi à antiguidade clássica como a viam os artistas do século XVIII, quando a peça foi escrita por Gluck. O mesmo artifício foi usado com Calderón no Príncipe Constante, onde embora o tempo da ação seja o século $\mathrm{XV}$, o autor a escreveu no século XVII, época que serviu de base para a montagem de 1915. Em Mascarada (1917) Meyerhold voltou-se para a aristocracia do século anterior; para o romantismo e o demonismo e, também, para os bailes de máscaras que, tal como na São Petersburgo de sua época, também eram extremamente populares na São Petersburgo de Liérmontov.

Angelo Maria Ripelino descreve de tal maneira o tradicionalismo de Meyerhold:

\footnotetext{
${ }^{50}$ Vsiévolod Meyerhod,op. cit., p. 126 [in. Ripelino, Angelo Maria. O Truque e a Alma. Perspectiva, São Paulo, 1996, p. 136]
} 
"Fruto de uma cultura rebuscada e exausta, o "tradicionalismo" é uma reconquista de velhas formas, uma tentativa de transferir para o presente os cânones de outras épocas idealizadas. $O$ diretor beneficia-se de artifícios do teatro de períodos remotos não para expor um arrogante bazar de engenhos defuntos ou para reconstituir modelos dignos de museu de figurinos e sim para incluir sopros de teatralidade nas cenas que haviam se tornado áridas pela rotina e pelo desleixo parasítico do naturalismo. Mesmo assim é estranho este tipo de vanguarda composta de tradição, uma vanguarda querendo rechaçar a banalidade reprodutiva dos procedimentos naturalistas, revolvendo os apagados (e por vezes bolorentos) hábitos cênicos de eras longínquas." 51

E continua mais adiante:

"Todos os aspectos do tradicionalismo têm, portanto, natureza de brinquedos (igrúchetchnost), estofo de bonecos (kúkolinost): linfa de murtinho ${ }^{52}$. E o que importa se lá fora a Rússia bate os dentes e se precipita em direção ao abismo. Os artistas cultivam com indiferença um limbo particular de estilizações teatrais. Presos no engodo do maneirismo eles agitam-se como

\footnotetext{
${ }^{51}$ Ripelino, Angelo Maria. O Truque e a Alma. Perspectiva, São Paulo, 1996, p. 142

52 Linfa ou suco de murtinho, planta consagrada a Afrodite na mitologia grega; muito perfumada, sua madeira também era usada para produzir incenso de mirra. Aqui é usada no sentido de uma panacéia capaz de embelezar tudo.
} 
abelhas num pote fechado entre as simulações, os enganos de épocas fabulizadas e esplendores ilusórios que gostariam de assumir como exemplo. Aterroriza-os a brutalidade do presente. Como sabe ser ausente, inútil, cheia de criancices, por vezes a não verdade do teatro." 53

O mais espantoso é que ainda assim, mesmo cultivando e revitalizando o antigo com tudo que isso tem de bom e de mau, Meyerhold encontrou o novo sem deixar de lado seu compromisso com a inovação e, muitas vezes, o fez brilhantemente. Assim, a Mascarada de Liérmontov tornou-se, junto com seu tempo, o último e talvez o mais espetacular suspiro deste tradicionalismo.

A notável e prolífica parceria entre Meyerhold e Golovin durou 15 anos totalizando vinte peças, entre elas Don Juan (1910), de Moliérre; as óperas Boris Godunov (1911) de Mussórgski e Orfeu e Eurídice (1911), de Gluk, com coreografia de M. Fókin; A Tempestade (1916), de Ostróvski; O Marido Ideal (1917), de Oscar Wilde; além de Mascarada (1917) e Dois Irmãos (1915) de Mikhail Liérmontov. Depois da revolução, Golovin encontrou cada vez menos trabalho e passou a se aprofundar na pintura e ilustração.

\section{A MASCARADA DE MEYERHOLD E GOLOVIN}

Mascarada teve sua estreia em 25 de Fevereiro de 1917, às vésperas da revolução. Na descrição de Robert Leech em Vsevolod Meyerhold,

\footnotetext{
${ }^{53}$ Ripelino, Angelo Maria. O Truque e a Alma. Perspectiva, São Paulo, 1996, p. 144
} 
"os participantes estavam tão absorvidos durante as últimas semanas de ensaio (...) que mal perceberam a revolução que se formava além das paredes do teatro. Apesar das demonstrações e da agitação geral, o interesse por Mascarada não diminuiu entre o público frequentador do teatro. (...) Ainda assim, com a revolução ganhando momentum, até mesmo chegar ao teatro para a première provou-se extremamente perigoso. lúri lúrev - Arbiénin na produção - foi obrigado a dar meia volta por um grupo de soldados só para ter sua passagem liberada mais adiante porque o comandante o tinha visto atuar; Meyerhold e Golovin tiveram que atravessar a avenida Niévski debaixo de balas; e pelo menos uma pessoa foi morta a tiros naquela noite ${ }^{54 ”}$.

Nos dias que antecederam a estreia podia-se ler nas páginas dos jornais de São Petersburgo anúncios de joalheiros que compram ouro, prata e joias a preços que aumentavam dia a dia, lado a lado com os endereços dos videntes, cartomantes e profetisas: "conheça seu destino!" Um visionário empreendedor que relatou ter vindo da Índia ou do Egito, rivalizava com quiromantes, adivinhos e as folhas de chá dos ciganos ao ler as cartas... Neste ponto, Meyerhold e Golovin mostraram à exaustão a morte da São Petersburgo imperial, um espetáculo esplêndido e terrível, magnífico e trágico. O cartaz da peça mostrava as palavras naquela época tão populares: "conheça seu destino." Só que, ao contrário de cartomantes e profetisas, Meyerhold não oferecia esperanças. O espetáculo profetizou desastres e fim do

\footnotetext{
54 Leach, Robert, Vsevolod Meyerhold, Cambridge University Press, 1989. P. 140
} 
mundo. "O Declínio do Império" - assim era chamada a performance. Seu outro nome foi "a última peça da Rússia czarista. "155

Teliakóvski, o administrador dos teatros imperiais mantinha diários sobre a época e no dia 26 de janeiro de 1917 anotou: "só quem fosse completamente cego e estúpido não perceberia a impossibilidade do país de continuar ser governada dessa forma." ${ }^{56}$ As multidões enchiam a avenida Niévski a ponto de interromper os ensaios, reconta Salomon Volkov em São Petersburgo: Uma História Cultural. Mesmo com seus cartazes de protesto pedindo pão, o ministro da Corte Imperial insistiu na estreia. Mas, Meyerhold estava animado com a possibilidade de montar uma produção cuja espontaneidade política beirava o ultraje. Assim, na noite de 25 de fevereiro, apesar da cidade estar vazia e lúgubre diante das manifestações, havia uma enorme fila de carros em frente ao teatro e nem o alto preço dos ingressos impediu que o Aleksandrínski estivesse lotado. Rudnítski descreve a reação de um crítico perplexo: "Tão perto, na mesma cidade, próxima do povo famélico - essa artisticamente pervertida, descaradamente corruptora, frenética e inútil luxúria em nome da mania sexual. O que era aquilo? A Roma dos césares? O que faríamos depois - comer línguas de rouxinóis, enquanto os bastardos famintos uivavam por pão e liberdade? ${ }^{, 57}$ Mas, o público aplaudiu de pé a esta primeira apresentação, flores e coroas de louros encheram o palco. A poetiza Ana Akhmátova, no entanto, não gostou do espetáculo, sua maior lembrança daquela noite foi a dificuldade de voltar para casa com toda a agitação na Niévski, homens a cavalo com as espadas desembainhadas, metralhadoras nos telhados e a dificuldade de encontrar um carro

\footnotetext{
${ }^{55}$ Rudnítski Meyerhold Regissior, Moscou, 1969, p. 205.

${ }^{56}$ citado em K. Rudnítski, Meyerhold, Moscou, 19881, p. 216. [in. Volkov, Salomon, São Petersburgo:

Uma História Cultural. Record, Rio de Janeiro, 1997, p. 216.

${ }^{57}$ Rudnítski, Regissior Meyerhold, Moscou, 1969, pp. 200-202. [in. Volkov, Salomon, São

Petersburgo: Uma História Cultural. Record, Rio de Janeiro, 1997, p. 218]
} 
ou coche de aluguel que a levasse até onde morava. ${ }^{58}$ Reprises de "Mascarada" estavam marcadas para 26 e 27 de fevereiro. "A segunda apresentação, apesar de todos os ingressos terem sido vendidos, só ocupou $50 \%$ da sala, a terceira teve de ser cancelada" - recordou I. E. Time ${ }^{59}$. O espetáculo foi repetido três vezes em março de 1917 e oito vezes em abril. ${ }^{60}$

Seguindo os preceitos do tradicionalismo, Meyerhold estendeu o proscênio unindo-o ao poço da orquestra com duas escadas e colocando simetricamente a seu lado balaústres, vasos e divãs. Golovin ergueu um suntuoso portal adornado por espelhos que no clarão dos castiçais reverberavam na plateia as luzes e a confusão das máscaras. O arco cênico foi projetado para se relacionar com a decoração e a arquitetura do Aleksandrínski

\section{AS ORIGENS}

O texto de Liérmontov, várias vezes recusado pela censura e nunca encenado durante a vida do autor, tomou quase seis anos de ensaios antes de chegar aos palcos pelas mãos de Meyerhold e Golovin. Meia década de muita pesquisa com figurinos e cenários, arquivos de museus, hábitos e costumes do início do século XIX. Apesar de sua estreia no Aleksandrínski, Mascarada era também fruto do trabalho no Estúdio da Rua Borodínscaia e como tal - ainda que encenado por atores do teatro imperial - tem muito da experimentação desenvolvida no Estúdio. Meyerhold "pesquisou e encontrou o equivalente em gestos para cada

\footnotetext{
${ }^{58}$ Volkov, Salomon, São Petersburgo: Uma História Cultural. Record, Rio de Janeiro, 1997, p. 219.

${ }^{59}$ Rabótchi i teatr (Operário e o teatro), 1926, n 15, p. 10

${ }^{60}$ Meyerhold Repetiruiet Moscou 1993.
} 
flutuação, cada emoção. Em outras palavras, ele deu a cada ator, em cada cena o tipo de atuação que, se desejado, poderia ser conduzida sem palavras, em mímica e ainda assim ser compreendida, ser 'lida’ pela audiência” ${ }^{61}$.

Mesmo austero, de libré e alamares no comandando dos teatros imperiais, Meyerhold não abandonou suas experimentações e caprichos em pequenos cabarés e palcos particulares. Mas, sem poder aparecer com seu próprio nome nos cartazes destas produções, adotou o pseudônimo de Doutor Dapertutto, o personagem de E.T.A. Hoffman, cuja descrição lembrava a do próprio Meyerhold: "um homem espigado e magro, com agudo nariz aquilino, olhos cintilantes, boca torcida num rictus, em um casaco vermelho cor de fogo com botões de aço brilhante" 62 conseguindo, assim, seu alter ego, o dopelgänger demoníaco perfeito para os engenhos e malícias de um teatro onde mais do que o texto, a mímica e o virtuosismo acrobático conquistavam seu espaço.

O Estúdio da rua Borodínskaia foi inaugurado em 1913 e durou seis temporadas até a primavera de 1917. Lá surgiu a "técnica do movimento cênico", que mais tarde seria fundamental na cuidadosamente orquestrada partitura de Mascarada, ainda que de forma muito mais contida. O eixo principal desta escola foi a pantomima, os atores eram treinados como ginastas, "deviam ter, prontidão acrobática, ritmo saltitante e festivo, a flexibilidade da chama. Meyerhold treinava-os a encaixar-se na essência da música guia, comedir a dialética dos movimentos às dimensões do palco, a colocar o corpo com harmonia no espaço designado." ${ }^{, 63}$ Foi um ambiente de muito estudo e aprendizado, o estudioso de teatro russo Vadim Scherbakóv em seu ensaio Os Motivos da Comédia de Máscaras Italiana na Arte de

\footnotetext{
61 Rudnitsky, Konstantin. Russian and Soviet Theatre, tradition and avant-garde, Thames and Hudson, London 1989, p. 23.

62 Ripelino, Angelo Maria. O Truque e a Alma. Perspectiva, São Paulo, 1996, p. 131.

${ }^{63}$ Ripelino, Angelo Maria. O Truque e a Alma. Perspectiva, São Paulo, 1996, p. 151
} 
Encenação Russa dos anos de 1910-1920 descreve assim as atividades do estúdio:

"todos deliravam com a comédia italiana. Vladímir Soloviov lecionava história e tecnologia, utilizando uma quantidade impensável de fontes científicas fundamentais. Estava preocupado com a implantação, em seus jovens tutelados, dos conhecimentos sobre as leis e o movimento no palco de cada uma das máscaras. Meyerhold ensinava improvisações plásticas sobre os temas das relações entre estas máscaras, os próprios membros do estúdio constantemente deviam escrever e encenar os esboços pantomímicos 'no espírito' da commedia dell'Arte. ${ }^{164}$

Mais adiante conclui que

"o ator pode 'vestir', como se fosse uma máscara, tanto a postura corcunda, quanto manca, o tique nervoso, a vaidade, desgraça, loucura e assim por diante, que em suma, compõem todo o complexo de tracinhos e traços do tipo apresentado. Dessa forma, a própria máscara torna-se para Meyerhold certo sistema, uma determinada combinação de movimentos do ator no palco.,65

\footnotetext{
${ }^{64}$ Cavaliere, Arlete e Vássina, Elena (orgs.)Teatro russo: literatura e espetáculo. Ateliê Editorial, 2011, pp. 85-86.

${ }^{65}$ Cavaliere, Arlete e Vássina, Elena (orgs.)Teatro russo: literatura e espetáculo. Ateliê Editorial, 2011, p. 90. [em itálico no original]
} 
A palavra permaneceu tímida na sombra da jonglerie diabólica, das mascaradas de Hoffmann, da Commedia dell'Arte e dos dramas espanhóis do Siglo de Oro de Calderón de la Barca. Nascia um teatro de movimento cênico, mais preocupado com a linguagem do gesto do quem com o diálogo, um teatro que tinha como aspiração "condensar a mímica num alfabeto de signos constantes, de formas-tipo, de movimentações codificadas." ${ }^{66}$ Uma nova forma de atuar que iria acompanhar Meyerhold e seus atores até os tempos soviéticos, prenunciando o nascimento da Biomecânica.

\section{A PESQUISA}

Nos teatros imperiais em 1917, Meyerhold e Golovin estavam finalmente prontos para a montagem comemorativa de Mascarada, que misturou a Commedia dell'Arte no caldeirão mágico de E.T.A Hoffmann, fazendo surgir a Veneza do século XVIII entrelaçada nas máscaras e nos dominós, uma produção que marcou o ponto culminante do período imperial no teatro Aleksandrínski assim como a colaboração entre diretor e cenógrafo. Enquanto a ideia de Meyerhold sobre a estranha e difícil peça de Liérmontov prevalecia, a concepção artística de Golovin predominava na eficiente e opulenta montagem, resultado de um sistema de trabalho desenvolvido em mais de uma década de parceria.

Meyerhold encontrou tempo para trabalhar em seu conceito sobre a peça em 1911; ao menos é o que escreve para sua esposa naquele ano sobre seu entusiasmo e o de Golovin ao visitarem o museu Liérmontov. Em uma carta de 28 de julho Meyerhold conta que esteve na datcha de Golovin e leu em voz alta para

\footnotetext{
${ }^{66}$ Ripelino, Angelo Maria. O Truque e a Alma. Perspectiva, São Paulo, 1996, p. 153.
} 
ele um capítulo sobre a Veneza do século XVIII do historiador da arte Pável Murátov, Imagens da Itália (Obrazy Italii, 1911). Em seu entusiasmo juvenil pela poesia de Byron, Liérmontov pode muito bem ter absorvido daí a cínica aura romântica de Mascarada, como Meyerhold descreve parcialmente nas palavras de Murátov:

“(..) esta atmosfera mágica de sonho. 'Máscaras, velas, espelhos - esta é a imagem de Veneza ${ }^{67}$ do século XVIII,' (...) os salões de festa onde 'é escuro apesar da luz das velas nos vários castiçais' (...) não seria esta a própria vida veneziana 'permeada de demonismo, sempre escondida sob as cartas e o ouro’ que pulsa nos personagens da Mascarada de Liérmontov - personagens que 'se encontram na fronteira entre o delírio e a alucinação. ${ }^{68, "}$

Em notas também de 1911 em sua primeira conversa com os atores, Meyerhold equipara Liérmontov a Arbiénin, de Mascarada, que acredita, é levado à destruição na peça pelo personagem do Desconhecido, assim como Liérmontov foi atiçado ao duelo em que foi morto pelas mãos de um assassino de aluguel do imperador. De modo geral, Meyerhold vê a peça como maior do que seu conteúdo literal e a mascarada como uma metáfora para a hipocrisia demoníaca daquela sociedade desocupada e corrupta com a qual Liérmontov rivalizou ao longo de toda

\footnotetext{
67 "Os simbolistas russos de fato associavam a fantasmagoria do carnaval de Veneza a relâmpagos e perfídias de espelhos, a deslumbres de morte, de águas palustres, de flores putrefatas. Na topografia onírica dos versos blokianos, Veneza torna-se fúnebre reverberação de uma espectral Petersburgo. As relíquias, as máscaras do século XVIII, a própria lembrança da cidade alagada condiziam em cheio com a liturgia das criptas que naqueles tempos se celebrava nos cabarés da capital nórdica, também sulcada por meandros de córregos e canais." (in Ripelino, opus cit, p.158)

${ }^{68}$ Stat'i, 1:343, Note 2 under V [lz zapisei]; refers to N. D. Volkov, Meierkhol'd, 2:183. In: Hoover, Marjorie L. Meyerhold and His Set Designers, Peter Lang Publishing, Inc., New York 1988, pp. 107108.
} 
sua curta vida.

A partitura composta por Meyerhold para a peça girava em torno da personagem desse Desconhecido (Neizvéstni) e, como coloca Ripelino, "na ideia de Meyerhold transformou-se num episódio de possessão demoníaca ${ }^{69}$." Na concepção de Liérmontov, no entanto, o "Desconhecido" é aquele que convence Arbiénin da inocência de Nina e os "dois diabretes mesquinhos", Chprikh e Kazárin, os orquestradores por trás da trama que levou Arbiénin ao ciúme doentio e ao inevitável assassinato da esposa.

Como vimos a peça gira em torno dos motivos da intriga, do ciúme e do destino. Depois de encontrar Arbiénin na mesa de jogo e salvar o Príncipe da miséria, os três vão para uma mascarada onde toda uma rede de intrigas, mentiras e mesquinharias envolvendo Chprikh, Kazárin, a Baronesa e até o Príncipe, levam Arbiénin a acreditar que está sendo traído e numa explosão vingativa envenenar a inocente Nina.

Tão empolgado quanto Meyerhold com o que acharam nos museus, bibliotecas e arquivos de São Petersburgo, especialmente os retratos, a mobília, os uniformes e desenhos do próprio Liérmontov que viram, Golovin juntou a este material as pesquisas mais recentes de sua última viagem ao exterior, para Paris em 1912. O incrível número de desenhos que produziu nestes anos de preparação para Mascarada resultaram em sete cortinas principais e dez panos de fundo para as dez cenas da peça, cerca de duzentos figurinos, mobílias e objetos - até mesmo xícaras de chá e cartas de baralho especialmente desenhadas. Tudo isso se encontra bem documentado em um soberbamente ilustrado volume com oitenta e oito reproduções, muitas em cores excelentes, publicado em 1941 em ocasião do

\footnotetext{
${ }^{69}$ Ripelino, Angelo Maria. O Truque e a Alma, Perspectiva, São Paulo 1996, p. 163.
} 
centenário de morte de Liérmontov, embora o livro omita qualquer menção ao nome de Meyerhold por ter sido publicado depois do diretor sofrer a "repressão ilegal sob o stalinismo".

Mais tarde, lúri lúriev (FIGURA 01), "um dos atores mais decorativos do teatro russo, gélido cinzelador de gestos nobres, zeloso das vistosidades, da dicção sonante, das poses de quadro." Embora proviesse de Moscou, do Máli, tornou-se o típico ator de Petersburgo: sua arte harmonizava com o túrgido esplendor dos uniformes, com a austeridade de parada das arquiteturas $\$ 70$. lúriev fazia Arbiénin na peça e deu uma descrição detalhada de quarenta páginas da produção em suas memórias. ${ }^{71}$ Também Golovin e seu assistente no livro de memórias do cenógrafo, descreveram em detalhes seu trabalho em Mascarada.

\section{A MONTAGEM}

Fosse Arbiénin um trágico herói romântico ou uma personagem patética como defendem alguns críticos que abordaremos a mais adiante, a montagem de Meyerhold faz jus às personagens e aos cenários suntuosos dos bailes descritos por Liérmontov. Golovin, além de cenários e figurinos, especificou também toda sorte de adereços, bibelôs, tinteiros, leques, estojos de maquiagem, carteiras, joias, vasos, relógios, etc. O proscênio foi estendido e adornado por duas escadinhas simétricas que desciam até a orquestra de ambos os lados do palco, ao lado, dois vasos azuisclaros, balaústres e divãs. Um pouco atrás, também arranjados de maneira simétrica, dois grandes espelhos que refletiam as luzes dos castiçais e do auditório

\footnotetext{
${ }^{70}$ In Ripelino, p, 138 - Cf A. Kúguiel, Iu. M. lúriev, in Profili tieatra, Moscou, 1929; Konstantin Dierjávin, lúri Mikhailovitch lúriev, Leningrado, 1939; la. Maliútin, Aktieri moievó pokolenia, LenigradoMoscou, 1959, pp, 71-105.

${ }^{71}$ lúriev, lúri Zapiski, 2: 197-231
} 
iluminado. Toda a simetria do mobiliário do proscênio contrastava com a assimetria por trás das cortinas que escondiam o palco principal.

Golovin e Meyerhold juntaram o palco e a decoração do Aleksandrínski, a cortina ficava levantada durante a apresentação de Mascarada, então, quando o público entrava no teatro, era surpreendido pelo arco do proscênio erguido sobre o palco parafraseando as estruturas de Rossi como se ecoasse as colunas das frisas e camarotes. Enquanto a arquitetura de Rossi trazia ornamentos dourados sobre fundo branco, Golovin decorou o palco com o reflexo desse motivo, estuques brancos em campo e ouro.

Somente duas das dez cenas do espetáculo ocupavam o palco todo, a mascarada e o baile. Durante os outros quadros, onde somente dois ou três personagens atuavam e os solilóquios, o espaço utilizado era relativamente pequeno. A decoração de Golovin com suas cortinas e véus fantasiosos que sugeriam o clima de cada episódio com sua simbologia e cores, conduziam uma peça própria e silenciosa acompanhando a performance dos atores e respondendo a ela. Véus e cortinas originais dividiam o progresso da peça com seus movimentos imprimindo um novo tom para cada episódio, ao mesmo tempo que criavam um senso de progressão acelerando o ritmo para o inevitável desfecho de morte e loucura. ${ }^{72}$

A divisão de Meyerhold em dez cenas deixa inalterada a versão mais aceita de Liérmontov para a peça com uma única exceção. Ele juntou o terceiro ao quarto ato do drama de Liérmontov, que consistia de uma única cena, o funeral da heroína e a punição do herói por sua morte, em uma estrutura clássica do século XVI. Os três atos resultantes precisavam de apenas dois intervalos que Meyerhold reduziu

\footnotetext{
${ }^{72}$ Rudnitsky, Konstantin. Russian and Soviet Theatre, tradition and avant-garde, Thames and Hudson, London 1989, p. 23.
} 
para meros quinze minutos cada, algo impensável para a época. A velocidade da encenação era o maior objetivo de Meyerhold, o que sem dúvida ajudava a frisar dramaticamente a abrupta urgência do ataque de ciúmes de Arbiénin e de sua vingança cega. Outra intenção do diretor era orquestrar o grande espetáculo da sociedade imperial com close-ups de certos elos que se entrelaçavam na intrincada rede de circunstâncias da peça, notadamente o bracelete de Nina, sua perda, a descoberta fortuita pela Baronesa e o presente enganador feito dele para o Príncipe.

Os meios pelos quais diretor e encenador usaram a rápida mudança de cena e a comunicação em primeiro plano imposta ao espectador eram os mesmos que vinham aperfeiçoando desde Don Juan e Orfeu e Eurídice. Outra vez incluíram todo o auditório com sua arquitetura e lustres iluminados na cenografia e, mais uma vez trouxeram o close-up, a cena em primeiríssimo plano, para frente do palco e para o proscênio. Tanto a sucessão rápida de cenas quanto os close-ups estão intimamente ligados à linguagem cinematográfica. Meyerhold de fato apoiou esta jovem forma de arte produzindo dois filmes como diretor e ator, O Retrato de Dorian Gray, baseado em Oscar Wilde (1915) e O Homem Forte, baseado em Stanislaw Pribisjevski (1916), infelizmente nenhum dos dois foi preservado. Em suma, Meyerhold e Golovin construíram com êxito as numerosas cenas na base da peça de Liérmontov, inclusive a velocidade e o memorável impacto visual de Mascarada utilizando-se dos meios teatrais que vinham desenvolvendo juntos já há algum tempo.

A dupla estendeu o proscênio do Aleksandrínski em semicírculo afixando um arco cênico com figuras esculpidas pelo assistente de Golovin Serguei Aleksándrovitch Evséiev para dar continuação à decoração barroca em ouro e branco do teatro. Eles substituíram a cortina principal com uma cor de framboesa 
decorada com tranças e franjas douradas. Véus e cortinas originais suplementavam esta cortina em cinco das dez cenas. Um palco móvel foi construído ao longo do poço da orquestra em frente à cortina principal com saídas para a esquerda e direita, assim, como escadas com corrimãos decorativos em ferro levando ao auditório em ambos os lados. Um momento crucial, como quando Nina perde o bracelete era encenado em pantomima, ela em um dominó branco e o pierrô que desprende o bracelete que cai despercebido no chão vestido de azul, ambos harmonizando com um canapé forrado de tecido adamascado tão longe quanto possível no centro do palco. (FIGURA 02) Mesmo que Golovin soubesse que o traje tradicional do pierrô fosse branco, conta Rudnítski, Nina vestia um dominó branco e Meyerhold insistia para que esta fosse a sua cor, consequentemente, na cena da pantomima entre os dois um pierrô de branco seria impossível. "Eu me lembro - continua B. Almedingen - como Golovin estava satisfeito quando, em algum livro velho encontrou uma imagem de um pierrô azul'73

Além de servir para as cenas em primeiríssimo plano, o proscênio também era usado nos solilóquios e nas atuações com poucos personagens em frente à cortina, enquanto o cenário era trocado atrás dela. Estes episódios individuais possuíam sua própria lógica interna e completude, quando a cortina era baixada escondendo a parte principal do palco, a cena continuava no proscênio, ou até mais próximo do público - como nos espetáculos do Dr. Dapertutto da Casa dos Entreatos, onde Meyerhold já subjugava o teatro de relação frontal e dilatava a ação para a sala toda - então a cortina subia e ação retornava ao fundo do palco. Meyerhold fragmentava até mesmo monólogos inteiros podendo começar a ação em um cenário, continuar no proscênio (as cortinas caindo por trás do ator) e terminar

\footnotetext{
${ }^{73}$ Rudnitsky, Konstantin. Regissior Meyerhold, Moscou, 1969, p. 247.
} 
ainda em outro cenário. A sucessão de cortinas se movendo davam uma impressão de incerteza e instabilidade para a produção, enquanto permitia ao diretor apresentar vários episódios em close-up, o que muito impressionou o futuro cineasta Serguei Eisenstein, presente na estreia de Mascarada. Em contrapartida, as cenas do baile e da mascarada causavam uma impressão esmagadora com suas composições, seus ornamentos e sua dinâmica nervosa. ${ }^{74}$

Marjory L. Hoover em Meyerhold and His Set Designers aponta que alguns críticos acharam que essas pequenas cenas em primeiríssimo plano fossem interrupções, como quando, antes do fim do diálogo no primeiro ato Arbiénin e o Príncipe Zviézditch avançam para o proscênio para completar sua conversa enquanto a cortina cai atrás deles sobre a mesa de apostas e os outros jogadores, o que causou grande estranhamento. No entanto, como vimos tal alternância do espaço antes e atrás de uma das várias cortinas permitia a rápida troca entre as cenas sem a necessidade de pausas. Assim, enquanto os atores da primeira cena saem pelas escadas laterais para continuar sua noite, no baile de máscaras, a cortina principal se ergue atrás deles para revelar a primeira cortina original, especialmente desenhada para a segunda cena. ${ }^{75}$ Além das cortinas, espelhos e véus colocados nas laterais aumentavam o tamanho do palco para as cenas mais espetaculares como a mascarada e o baile branco em sociedade ou reduziam-no como na opressiva e confinada caixinha que se tronou a alcova do quarto de Nina. Golovin notou ainda outra função nos espelhos, assim como Murátov achou típico em Veneza: "Os espelhos foscos colocados em ambos os lados do proscênio refletiam as luzes para o auditório. Isto, por assim dizer, eliminava a divisão entre a

\footnotetext{
${ }^{74}$ Rudnitsky, Konstantin. Russian and Soviet Theatre, tradition and avant-garde, Thames and Hudson, London 1989, p. 23.

${ }^{75}$ Hoover, Marjorie L. Meyerhold and His Set Designers, Peter Lang Publishing, Inc., New York 1988, p. 109.
} 
plateia e o palco."76

A primeira das cortinas da peça (FIGURA 03), bordada em vermelho e negro com o emblema de um leque de cartas de baralho ao centro envolto por laços e grinaldas, introduzia a performance antes mesmo dela começar; outras três serviam de sustentação para a peça durante os intervalos, criando um determinado estado de espírito. A quinta e última cortina, uma rede em tule preto, caía ao final como um véu de luto. Todo o resto, cenário, decoração, figurino, surgia como mais um ingrediente natural no palco trágico, acentuando a inevitabilidade do destino.

A cortina da segunda cena (FIGURA 04), a mascarada, é a primeira das cinco originalmente desenhadas para a peça. Decorada com muitas fitas, sininhos que retiniam com o movimento e painéis recortados que permitiam que as figuras fantasiadas fossem entrevistas por trás dela mesmo antes que subisse; era em sua maior parte verde, decorada com flores e folhagens e, quando subia, revelava um salão vermelho, verde e amarelo onde no fundo do palco, uma balaustrada atrás da qual um orquestra tocava. Ripelino descreve este primeiro baile, a mascarada, como um turbilhão de máscaras que construíam fugazes emaranhados e contrastes de manchas pictóricas enquanto um velário baixava e subia várias vezes suscitando a ilusão de cômodos que iam se abrindo à dança de roda dos bailarinos que despontavam por entre suas fendas. Neste bando, de repente, o Desconhecido (FIGURA 05) introduzia seu semblante caliginoso e seu perfil de ave de rapina: "as máscaras primeiramente petrificavam e depois, quase fantasmas noturnos ataviados por echarpes multicores, começavam a girar ao seu redor, sonâmbulas, sugadas pelo centro magnético da iminente tempestade. ${ }^{\prime 77}$

Golovin produziu quase 175 fantasias para essa segunda cena, a introdução

\footnotetext{
${ }^{76}$ Hoover, Marjorie L. Meyerhold and His Set Designers, Peter Lang Publishing, Inc., New York 1988, p. 110.

${ }^{77}$ Ripelino, Angelo Maria. O Truque e a Alma. Perspectiva, São Paulo, 1996, p. 165.
} 
dos cadernos de ensaios de Meyerhold sobre a montagem dos anos 30 descreve quão grandiosa foi a cena (FIGURAS 06 A 12)

"personagens da comédia popular italiana guiadas pelo Pierrô Azul arrancando o bracelete do pulso de Nina; um herói das Mil e uma Noites; personagens de óperas populares; representantes de diferentes nacionalidades e seus trajes típicos; diversos naipes de cartas do baralho; dominós de todas as cores; fantasias sem par: a morte; uma dama veneziana; um cupido; um anão; a marquesa... inacreditável, - 'mauritanos'”, enumerou Beliaiev em seu artigo de 1941, sublinhando que "claro, não é somente o baile de máscaras na casa dos Enguelgardt, mas o verdadeiro baile de máscaras da vida" ${ }^{78}$

A segunda cortina, ou a cortina do baile em sociedade (cena VIII) realçava listras brancas, douradas e prateadas; um desenho floral estilizado com tranças em franja ao fundo em curvas drapeadas para combinar com as tranças similares na tapeçaria do arco acima. O salão de baile (FIGURA 13) em mármore que aparecia quando era erguida estava pontuado por colunas de malaquita, friamente decorado com um piano de madeira de bétula e cadeiras brancas estofadas em seda amarela e dourada, uma clara antítese ao turbilhão de cores e movimento da mascarada.

A terceira cortina de renda prateada parecia abraçar a indefesa Nina (cena IX) contraindo o espaço cênico de sua alcova que, reduzido a uma estreita caixinha, era utilizado para enfatizar a situação inevitável de sua morte indesejada. O espaço

\footnotetext{
${ }^{78}$ Meyerhold Repetiruiet Moscou 1993, p. 311.
} 
confinado deste nicho de rendas brancas e azul claro se encontrava oculto nos lados e acima por pesadas cortinas azul escuras, as rendas brancas aludindo à inocência de Nina ao mesmo tempo que enfatizavam o negrume secreto do que estava por vir.

A quarta (FIGURA 14), a cortina do velório de Nina (cena X), de tule negro como um véu, era erguida para revelar uma antecâmara na casa de Arbiénin de onde portas duplas no centro do palco levavam para o quarto onde, fora de cena, o corpo de Nina se encontrava em um esquife. Um coral executava cantatas de um réquiem nos bastidores acompanhando o lento enlouquecer de Arbiénin. Rudnítski assim descreve a este trágico desenlace:

"O final do espetáculo inspirava 'um horror e mistério infernal.' A cena da loucura de Arbiénin jogado contra o pano de fundo enquanto cantava-se o réquiem. Espelhos, retratos, pilares todo o grande salão estava coberto por um véu negro de luto. Na entrada para a sala onde estava o caixão uma multidão com velas acesas $[\ldots]^{\prime 79}$

Finalmente, depois do embate com o Desconhecido, uma cortina preta especial caía sobre um Arbiénin caído de joelhos no centro do palco concluindo o espetáculo. (FIGURA 15)

Com seu costumeiro perfeccionismo, Golovin supervisionou a tomada de medidas e a confecção de todos os figurinos e acessórios, cada um deles feitos com materiais originais e sob medida para este ou aquele ator e, até mesmo, para os pupilos do estúdio que serviam de "extras." Uma delas, Vera Smirnova, contou que

\footnotetext{
${ }^{79}$ Rudnítski, K. Meyerhold Regissior, Moscou, 1969, p. 212.
} 
dois figurinos foram feitos para ela: o primeiro (FIGURA 16), o de uma dama fantasiada no baile de máscaras, incluía uma anágua especial em seda com armação de arame; enquanto o segundo, uma roupa de luto para o funeral, precisava até de uma boininha preta.

As cores eram combinadas de forma a significar algo, primeiro em cada personagem, depois em cenas inteiras e, finalmente, na progressão das cenas até o sinistro fim da peça. Assim, Nina vestia branco, denotando pureza tanto na mascarada (FIGURA 17) quanto mais tarde no baile em sociedade (FIGURA 18). Este vestido, ao qual Golovin ainda acrescentou uma cauda de veludo negro prenunciando a morte, era certamente o mais elaborado dentre todas as centenas de figurinos que desenhou.

Somente um dos cenários era repetido, o da mesa de jogo, prenunciado pelo leque de cartas, o emblema central entre as máscaras negras e painéis da cortina vermelha principal usada ao longo de toda a produção. A cena inicial da jogatina (cena I) lançava uma nota sinistra e ameaçadora com sua luz baixa vindo de um cone de luz sombreado de verde sobre a mesa redonda onde se encontravam os jogadores (FIGURA 19); mais ameaçador ainda era o seu retorno (cena VII) no local da planejada humilhação do Príncipe por Arbiénin (FIGURA 20). Ripelino assim descreve o contraste entre as duas cenas:

"Se no primeiro destes episódios um pano de fundo esverdeado e inúmeros biombos de rosáceas arroxeadas cercadas de negro conferiam-Ihe apagada tenebrosidade, no outro, ao contrário, paramentos avermelhados como línguas de fogo e uma incandescente parede escarlate (com uma janela 
pela qual avistava-se, no espesso negrume do céu, uma sanguínea lua bicorne) transmitiam o clima sufocante de um terrivel inferno do jogo.

No episódio final, depois de humilhar o Príncipe e vingar-se de Nina Arbiénin se encontrava sozinho com seu pesar na antessala do velório, o Desconhecido surgia então ao som do réquiem por trás do véu negro do cenário como um taciturno porteiro do inferno, de cartola preta e sobrecasaca com botões de metal branco. Até então, esta personagem infernal permanecia em segundo plano, mesmo no louco e colorido movimento da mascarada, a figura agourenta do Desconhecido, com uma capa negra e uma máscara veneziana com um bico de falcão, estava sempre encoberta pelas máscaras e dominós coloridos girando em seu redor.

Entretanto, havia também momentos mais leves em Mascarada, como a sala onde a Baronesa recebe Nina, o Príncipe e depois o grotesco Chprikh (FIGURA 21) na manhã seguinte ao baile de máscaras (cena IV), com suas janelas francesas deixando entrever um jardim ou, de novo, o brilhante e claro, ainda que frio salão de bailes em mármore com sua mobília branca. Mas, a despeito destes momentos iluminados, os figurinos e cenários tendiam sempre para o sombrio desfecho da tragédia e o preto do luto com suas coroas de flores negras da cena final (cena X).

\section{OS DESDOBRAMENTOS}

Nas falas de Arbiénin, Mascarada se transforma em uma metáfora para o cinismo, a hipócrita - ou o demonismo até - da aristocracia russa. Este significado,

\footnotetext{
${ }^{80}$ Ripelino, Angelo Maria. O Truque e a Alma. Perspectiva, São Paulo, 1996, p: Cf. M. Beliáiev, op. Cit., pp 46 e 47-48.
} 
que Meyerhold e Golovin trouxeram a tona em sua luxuosa produção, acabou sublinhado pela coincidência histórica: a revolução de fevereiro, que destruiu a Rússia imperial, começou na noite de estreia da peça em 25 de fevereiro de 1917. Ironicamente, "nem com todo o seu fatalismo pessimista ele [Liérmontov] poderia prever que a Mascarada - O Ocaso do Império, segundo os atores - seria o último ato da velha Rússia, batida pelas ondas revolucionárias. Tal coincidência lhe teria parecido o cúmulo da ironia romântica"811 aponta Solomon Volkov.

A forma como Arbiénin (FIGURA 22) encara a vida, como se fosse um jogo de cartas - onde cada gesto ou movimento do parceiro ou do oponente significa alguma coisa pedindo um contra-ataque imediato - e sua própria confiança em sua sabedoria, claramente conduzem ao desastre. Segundo Vladimir Golstein, Chprikh funciona como uma paródia grotesca de Arbiénin, enquanto Arbiénin se imagina um guerreiro lutando contra toda a maldade do mundo, contra máscaras dissimuladas seja no jogo, seja na sociedade representada nos bailes - Chprikh é quase um personagem cômico, cuja falta de escrúpulos e o egoísmo são constantemente manipulados pela Baronesa para alcançar seus objetivos. Kazárin, por sua vez, é a personificação do demônio, antigo colega e parceiro de jogatinas de Arbiénin, ele é um jogador cínico e manipulador que só acredita na realidade do mal. ${ }^{82}$

lúri Mann no capítulo onze de Dinâmicas do romantismo russo observa que "as imagens da "mascarada" e do "baile" de um lado, e do "jogo" - do outro, possuem os significados contrastantes e que este contraste define toda a estrutura do drama." A mascarada não é apenas uma imagem de luta vital, mas de uma luta sob o disfarce de um estranho, a imagem da rivalidade latente. A máscara equilibra as diferentes posições ("Sob a máscara todas as classes são iguais ..."); a máscara

\footnotetext{
${ }^{81}$ Volkov, Salomon, São Petersburgo: Uma História Cultural. Record, Rio de Janeiro, 1997, p. 217.

82 Golstein, Vladimir. Liérmontov's Narratives of Heroism, Northern University Press, 1998.
} 
esconde as diferenças emocionais ("As máscaras não têm alma, nem patente - têm somente o corpo"); a máscara torna invisíveis as vibrações internas e as indecisões. $^{83}$

A mascarada é um sinal de sinceridade incomum, de naturalidade, da descoberta daquilo que na vida cotidiana é limitado pelo decoro e a etiqueta. Uma transformação curiosa: o disfarce da mascarada torna-se um tipo de antimáscara e o rosto aberto da comunicação cotidiana vira-se em máscara dissimulada ("máscaras carentes de decência"). E, assim, a Baronesa Shtral (FIGURA 23), escondendo normalmente "todas as chamas de seus sentimentos" sob a máscara de polidez e frieza fingidas, na mascarada, sem ser reconhecida, fala com o Príncipe Zviézditch (FIGURA 24) a linguagem do coração e da paixão. A imagem do mais refinado e convencional permitido pela etiqueta irregular, incluindo esta "irregularidade", como sentimento sincero.

Ainda segundo Mann, a verdadeira antítese da Mascarada se mostra de outra forma no carteado. O jogo é um desvio em relação às regras convencionais, em vez delas aparecem outras inferiores. O jogo de cartas é o rompimento das ligações, naturais e sociais ("A tudo desprezo: a lei dos homens, a lei da natureza"). E a sorte de jogador em todos os momentos está sob ameaça, é vulnerável em termos de direito consuetudinário e de moralidade ("... cada momento de espera final é vergonhoso").

Os jogadores são uma sociedade dentro da sociedade, ou melhor, são pessoas rejeitadas pela sociedade. A mesa de jogo é um mundo inferior e, como a luta da sociedade está personificada pelo baile de máscaras, o jogo é o piso inferior desta mascarada, o submundo da Mascarada. E a entrada no círculo de jogadores é

${ }^{83}$ Манн Ю.В. М 23. Динамика русского романтизма. - Москва: Аспект Пресс,. 1995, pр.286 305 
o equivalente à queda, à decadência. ${ }^{84}$

Já para Elisabeth Cherish Allen, Arbiénin é mais patético do que um trágico herói romântico, "se é uma vítima, Liérmontov sugere e, como vimos, Meyerhold acentua, ele é uma vítima de suas próprias necessidades psicológicas de glorificação, que satisfaz através de uma ideologia que o deixa cego para o mundo a seu redor $^{85}$."

Ripelino, por sua vez, coloca que "os heróis liérmontovianos se inflamam sem remédio e amam com uma furiosa obstinação que depois se desfaz, como nos rios caucásicos, em uma espuma fúnebre. É tão desmesurada a paixão que acabam matando por ninharias a amada, por excesso de amor. ${ }^{866}$ Para ele, Arbiénin vem de uma juventude de jogos e intrigas e procura no casamento a salvação cortando os vínculos com a vida pregressa. Mas, como o texto da peça mostra, um homem depende tanto de seu passado que não pode libertar-se dele e, dessa forma, se consome de melancolia pela juventude perdida se imaginando no lugar dos maridos que enganara em outros tempos.

Como Golstein e Mann, Ripelino também nota a metáfora do jogo, apontando como as personagens de Liérmontov repetem em manobras miméticas as instabilidades e os altos e baixos do destino como num jogo de azar. "Da febre do jogo nasce a metafísica do equívoco: suspeitas, ofensas, incompreensões, brigas, perseguindo-se em ritmo acelerado, dando ao drama a flutuação e a incandescência de uma partida de faro. ${ }^{, 87}$

O Faro (ou faraó), jogo da moda na Rússia dos séculos XVIII e XIX usado

\footnotetext{
${ }^{84}$ Манн Ю.В. М 23. Динамика русского романтизма. - Москва: Аспект Пресс,. 1995, pp.286 - 305

${ }^{85}$ Allen, Elisabeth Cheresh. A Fallen Idol is Still a God: Liérmontov and the Quandraries of Cultural Transition, Stanford UP, 2006, p. 119

${ }^{86}$ Ripelino, Angelo Maria. Letteratura comme Itinerario nel Maravilloso, Barral Editores, $1970, \mathrm{p}$. 92.

${ }^{87}$ Ripelino, Angelo Maria. Letteratura comme Itinerario nel Maravilloso, Barral Editores, 1970, p. 94.
} 
como modelo de construção literária na Dama de Espadas de Púchkin e O Jogador de Dostoiévski, é tão rápido que não existe modelo melhor para ilustrar a obrigação de se tomar decisões sem ter as informações necessárias para isso. No tempo de duas ou três frases o jogo foi feito, as cartas viradas e o vencedor revelado, resta ao jogador aceitar seu destino. Para o estudioso e teórico de literatura russa lúri Lottman,

"A situação do faraó - antes de tudo - é a situação de um duelo: modeliza-se o conflito de dois adversários. Contudo, na própria essência deste modelo leva-se em conta a sua desigualdade: o apostador - aquele que deseja ganhar tudo, embora com isso se arrisque a perder tudo - comporta-se como alguém obrigado a tomar decisões importantes, sem possuir a informação necessária para isto [...] O banqueiro, por sua vez, não elege nenhuma estratégia. Além do mais, certamente, aquele que está bancando não sabe qual será o arranjo das cartas. Representa uma espécie de títere nas mãos dos Fatores Desconhecidos que se encontram por trás dele. Tal modelo por si só já ocultava determinadas interpretações dos conflitos da vida. O jogo tornava-se um confronto com uma força poderosa e irracional, percebida amiúde como demoníaca." 88

Arbiénin enlouquece depois do confronto com o "Desconhecido”, personagem

${ }^{88}$ LOTMAN, IUri: A Dama de Espadas e o Tema das Cartas e do Carteado na Literatura Russa do Começo do Século XIX. In Caderno de Literatura e Cultura Russa, 2004, p. 101-102. 
que o convence da inocência de Nina e revela os limites de sua sabedoria. Por não conseguir incorporar o que lhe é ignorado na metáfora que escolheu para a vida, Arbiénin é punido pelo Desconhecido. Essa mensagem era tão importante para Liérmontov que para transmiti-la ele estava disposto a quebrar as normas do gênero e introduzir uma figura simbólica num drama romântico.

Durante o período soviético, as discussões abertas sobre a moral, a religiosidade e o significado nacional de Liérmontov deram lugar ao projeto oficial de definir um novo cânone literário ideologicamente demarcado, mas, ainda assim, projetado para tirar todo proveito possível da autoridade consagrada das grandes figuras literárias pré-revolucionárias da Rússia ao cooptá-las. O valor literário dos ilustres autores do inicio do século XIX foi redefinido para encaixá-los em uma historia cultural que fora reescrita para conduzi-los irrefutavelmente para a revolução. Assim, bem depois de sua morte, o surreal e grotesco Gógol foi, quase que por milagre, transformado em realista. Os trabalhos mais tardios de Púchkin e Liérmontov se viram enquadrados ostensivamente nos termos de sua evolução em direção ao realismo. Mesmo durante períodos relativamente liberais, certas restrições ideológicas e institucionais limitavam bastante as direções que a academia soviética podia tomar e com ela as artes e o teatro. $\mathrm{O}$ sistema desencorajava especialmente redefinições radicais de figuras canonizadas. Sob tais circunstâncias, os acadêmicos eram obrigados a passar ao largo do que era moralmente ou politicamente problemático na obra de Liérmontov, ou seja, precisavam simplificá-la para produzir interpretações relativamente "seguras".

O romantismo foi por muito tempo um assunto tabu na academia soviética. Quando surgia de alguma forma nos estudos sobre Liérmontov, era sempre para enfatizar a evolução do poeta em direção ao realismo. Enquanto essa tendência 
dogmática ia aos poucos desaparecendo no começo dos anos de 1960, os debates sobre se Liérmontov era um romântico ou um realista giravam em termos de "método artístico" e "estilo." ${ }^{89} \mathrm{O}$ termo "individualismo," sem dúvida o traço mais marcante do romantismo, raramente era invocado, pois conservava a conotação política pejorativa exclusivamente associada com o "individualismo burguês." O termo efetivamente transpunha um conceito filosófico para um indiscutível, objetivo, e politicamente demarcado léxico de luta social. $\mathrm{O}$ preconceito contra o individualismo romântico era tão forte que o próprio termo quase nunca era aplicado a Liérmontov ou qualquer outro escritor russo digno de nota.

Meyerhold fez diversas releituras de sua montagem de Mascarada até a sua morte nos anos 30, retirando elementos simbolistas e até diminuindo muito da pompa e do esplendor da montagem original para adequá-la à tempos mais austeros. Já na temporada de 1917/18, depois de onze apresentações, Mascarada saiu do repertório. Um jornal de São Petersburgo, Vetcherhii Zvon de 15 de dezembro de 1917 informava:

"No começo da atual temporada, surgiu a questão da renovação de Mascarada. Esta reformulação despertava pouca simpatia entre os atores e o diretor. A produção 'grandiosa' foi considerada inapropriada para o momento presente. Por outro lado, o Aleksandrínski abriu com atraso. E, por sua vez, existiam outras atrações. Havia esperança que Mascarada voltasse à cena. Esperanças estas, que por hora não iriam se concretizar. A remontagem de Mascarada era simplesmente

\footnotetext{
${ }^{89}$ Polwelstock, David: Becoming Mikhail Liérmontov: the ironies of romantic individualism in Nicholas I's Russia. Northwestern University Press, Evanston, Illinois, 2005, p. 9.
} 
impossível, já que grande parte dos participantes havia se dispersado. Também não estava mais há disposição do teatro a mão de obra necessária para uma produção tão complexa como Mascarada". 90

Desde então entrou e saiu do repertório diversas vezes, atores foram substituídos e mais tarde voltaram ao papel; a orquestra completa que tocava sobre o palco e os inúmeros figurantes foram aos poucos dispensados e até a direção mudou de mãos. Ainda assim Mascarada permaneceu uma joia do teatro russo. Sendo encenada mais de 200 vezes. Parecia não envelhecer nunca e, mesmo depois de ter seus figurinos e cenários destruídos por uma bomba durante a Segunda Guerra Mundial, continuou a ser montada e ter sua música, composta por Glazúnov, tocada durante a ocupação.

Meyerhold quase sempre já tinha uma peça inteiramente pronta na cabeça bem antes de começarem os ensaios. Ele aparecia com um projeto detalhado que cobria desde a iluminação até os figurinos e objetos de cena. Golovin não se incomodava, pescava as ideias de Meyerhold no ar e as tornava realidade, pois, como vimos, sua contribuição vinha do domínio das cores, dos ornamentos, de suas fantásticas composições; da sua percepção de profundidade de palco, que majestosamente destacava delimitando os diversos planos. Seu senso de estilo era ímpar, nunca copiava ou reaproveitava objetos, figurinos ou acessórios, criava sempre novos. Era capaz de enriquecer os desenhos e esquemas de Meyerhold materializando-os em entidades artísticas únicas.

\footnotetext{
${ }^{90}$ Meyerhold Repetiruiet Moscou 1993, p. 312.
} 
Ainda assim, como conta Rudnítski em Meyerhold diretor, as tarefas mais complexas foram direcionadas para o trabalho com os atores. Durante os ensaios alguns papeis passavam repetidamente de mão em mão, muitas vezes, até o momento da estreia. O maior desafio de Meyerhold foi Arbiénin, quão grandiosa deveria ser a amplitude da vibração na interpretação deste papel? De acordo com dois registros de 1911, "Arbiénin é uma visão negativa da luz [...] Liérmontov queria escrever uma comédia nos moldes de "A desgraça de ter espírito" de Griboiédov. Mas em Mascarada, fez uma sátira. [...]. Em outra anotação aponta "o 'pietchorismo' de Arbiénin. Características autobiográficas: Liérmontov - Pietchórin - Arbiénin”. No final prevaleceu o segundo conceito do papel, mais próximo da verdade. E, muitos anos mais tarde em 1939, lúriev notou, particularmente por que a interpretação não mudou ao longo dos anos: "Arbiénin apareceu diante de mim pela primeira vez em meu trabalho tão claramente definido, que a maneira como ficou retratado em minha mente foi como tentei, ou melhor, como estamos tentando retratá-lo até esta data," enfatizando especialmente estes traços autobiográficos que apresentam a figura de Liérmontov. "Arbiénin tem - escreveu - como sua principal e autobiográfica, [característica] as densas cores com que Liérmontov o pintou, não parece olhar para trás.

Unindo as personalidades de Arbiénin e Liérmontov, Meyerhold pretendia reforçar sua representação do Desconhecido, a quem imaginou como o assassino do poeta, Martínov. O papel do Desconhecido estava sendo esplendidamente ensaiado por V. P. Dalmátov. "Sentia-se qualquer coisa estranha em sua aparência, um frio penetrante emanava de seu tom de voz e impregnava a atmosfera de horror e, como se diz, provocava arrepios”. Mas Dalmátov morreu muito antes da estreia e

\footnotetext{
${ }^{91}$ Rudnitsky, Konstantin. Regissior Meyerhold, Moscou, 1969, p. 208
} 
o papel passou para outro jovem artista que, segundo lúriev escapou com honras desta situação tão difícil.

lúriev, por sinal, erigiu um verdadeiro monumento a Meyerhold em suas memórias. Mesmo impedido de citar o nome do diretor depois de sua morte no período stalinista, reservou, com muito carinho, um longo espaço para a reconstrução da imagem literária da peça e ao trabalho de seus colegas de palco:

"Nina, Roshchina-Insarova - descreveu - traz a atmosfera dos anos 30: sua aparência, seus modos, a maneira de falar - tudo para expor a culpa daquele ambiente ao redor da heroína e que nutriu esta flor tão feminina. Reforçando aos olhos dos outros a elegância, a beleza e a feminilidade inata que apareciam nos olhos [da atriz] Duse - antes você, a verdadeira Nina."

A Baronesa Shtrahl, E. Time. "A espetacular presença de palco, a capacidade de dominar sua figura, sua voz musical, a bela leitura do verso, o temperamento e o eloquente desempenho geral - ajudaram o diretor talentoso a criar a expressiva imagem de Liérmontov da baronesa.

Kazárin está muito típico na pele de V. Gorin-Goriáinov. [...] todas as pessoas puderam sentir sua experiência de vida, seu passado, em meio ao fogo, água e tubulações de cobre. Um homem de inteligência excepcional atribuída a ele por natureza. O olhar impressionante. Sabia se comportar em sociedade, assim como deixava a impressão de ser um leão 
social. Falava com os outros orgulhoso, mas, um pouco condescendente, paternalista e, por vezes, dava para sentir que era superior. Era perspicaz, espirituoso e, a seu modo, popular. Este foi o Kazárin retratado por Gorin-Goriáinov. ${ }^{92}$

A partitura de palco para Mascarada ditava acima de tudo a observação do ritmo dos versos de Liérmontov, em seguida as mudanças no espaço cênico considerado de antemão e por último, mas, não menos importante, movimentos corporais obrigatórios para denotar qualquer mudança de emoção. A partitura assumia o movimento corporal como um sinal ('pausa') dentro dos limites de cada movimento emocional. As formas concretas podiam ser as mais diversas: luvas atiradas sobre o piano - 'pausa'; inclinar-se na cadeira - 'pausa'. Essas pausas podiam ser mais ou menos aparentes para a plateia, mas, essa não era a essência; a essência era que o ator não tinha o direito de omitir nenhuma das 'pausas'.

Anos mais tarde, sem nenhuma relação com Meyerhold ou sua montagem de Mascarada, lúri Lottman iria escrever sobre o jogo de cartas:

“O faraó modeliza também seu universo próprio. Antes de mais nada ele é assinalado por uma fragmentação máxima (assim como qualquer modelização dos fenômenos da vida com a ajuda da língua): uma unidade se destaca - "a parada" situada entre o "começo" e o "fim" da ação, sendo que o primeiro é assinalado pela transição de uma situação plana e sem importância (o nada, do ponto de vista do jogo) para ações

\footnotetext{
${ }^{92}$ Rudnitsky, Konstantin. Regissior Meyerhold, Moscou, 1969, p. 210
} 
que visam a uma melhoria abrupta do seu status (o ganho). A condição psicológica do herói nesse ponto do enredo baseia-se na esperança. O momento do encerramento é assinalado pela destruição final (a perda, que nunca é nem parcial, nem muito significativa, mas acarreta a ruína ou a loucura do personagem) ou pela vitória, que também possui um caráter escatológico. ${ }^{903}$

Muito antes de o estudioso e semioticista russo usar os conceitos de "parada", ou como preferiu Meyerhold - "pausa" - e o movimento vertiginoso da partida como metáfora da condição psicológica do herói, o genial diretor colocou-os de pé em uma montagem brilhante, enxergando no drama trágico de Liérmontov o mesmo universo próprio sobre o qual Lottman viria a teorizar mais tarde.

O sistema de "pontuação" criado por Meyerhold obedecia a um ritmo fixo ditado pelo diretor, o ator ficava subordinado à partitura. E isso não é um paradoxo, pois, toda a organização rítmica da produção não só induz no ator a emoção necessária como cria espaço pra ela e lhe dá liberdade. Mais importante, o conhecimento da partitura traz calma interior ao ator, confiança em si mesmo e em seu direito de enriquecer a partitura com uma multiplicidade de nuances acessíveis somente a ele. Na atuação opulenta de Mascarada surgiam os fundamentos do que no futuro viria a ser o conceito de "biomecânica", que apareceu depois da revolução em espetáculos muito diversos de Mascarada, ascéticos, severos e destituídos tanto do sentido de fatalidade quanto do brilho carnavalesco. ${ }^{94}$

Em retrospecto, o simples sistema nascido da colaboração entre Meyerhold e

\footnotetext{
${ }^{93}$ LOTMAN, Iuri: A Dama de Espadas e o Tema das Cartas e do Carteado na Literatura Russa do Começo do Século XIX. In Caderno de Literatura e Cultura Russa, 2004, p. 101-102.

${ }^{94}$ Rudnitsky, Konstantin. Russian and Soviet Theatre, tradition and avant-garde, Thames and Hudson, London 1989, p. 23.
} 
Golovin que culminou em Mascarada predominou também nas criações de 1908 a 1918 nos teatros imperiais, ou seja, a alternância do espaço cênico entre as cortinas do proscênio e os panos de fundo decorados para sugerir situações e mostrar perspectivas mais distantes. Ainda assim, muitas das características cenográficas da década imperial de Meyerhold, assim como a mudança de paradigma que originou, marcaram as encenações subsequentes do diretor nas duas décadas soviéticas que vieram a seguir.

Mascarada (1917), a mais duradoura das encenações de Meyerhold e Golovin, foi renovada várias vezes. As cortinas ornadas para o proscênio e outros véus e cortinas originais foram usados para recriar o esplendor da celebração e facilitar a troca rápida entre as cenas. Tal solução pré-revolucionária com tantas cortinas antes e atrás das cenas resolveu um problema geralmente considerado característico do expressionismo pós-revolucionário e, também, ajudaram quebrar a barreira que separava palco e plateia, tão grande nos vastos teatros europeus com seus poços para orquestra, o que proporcionou e intensificou a atuação em primeiro plano. $^{95}$

Com sua estreia na noite da Revolução de fevereiro, Mascarada "foi não somente a síntese e a conclusão do teatro 'convencional', como também o réquiem, o apogeu, o monumento de uma época da arte russa. ${ }^{, 96}$ Liérmontov não poderia querer melhor estreia, escrita nos anos de 1830, logo após o levante dos Decembristas, a peça ilustra algumas das preocupações tradicionais da sociedade: jogos de cartas, duelos e bailes de máscaras; passatempos comuns também na década anterior (mas, de uma forma mais ingênua), que tiveram um repentino revival nos anos 30 do século XIX. A peça examina as atividades mais populares da

\footnotetext{
${ }^{95}$ Hoover, Marjorie L. Meyerhold and His Set Designers, Peter Lang Publishing, Inc., New York 1988, p. 205.

${ }^{96}$ Ripelino, Angelo Maria. O truque e a Alma, Perspectiva, 1996, p. 197.
} 
sociedade da época e aborda este revival com cautela, se não criticamente. As três atividades separadas e por si só diferentes, têm coisas em comum, todas expressam a necessidade de se render ao desconhecido e à sorte como que para evitar a dominação total do Tsar e de suas patrulhas, escapar de um controle social e cultural que havia se tornado intolerável. A nobreza russa, esmagada pelas punições e incapaz de manifestar sua individualidade ou dignidade, precisava recorrer a manifestações um tanto forçadas dessas qualidades. Dessa maneira, jogatinas, duelos e mascaradas são testemunho não tanto da depravação das classes governantes, mas de sua busca desesperada por independência, anonimato e fuga do controle totalitarista. ${ }^{97} \mathrm{Na}$ montagem de Meyerhold, "o fervilhar de figuras maléficas, a redução das personagens a instrumentos do destino, o redemoinho de máscaras não passavam de indícios de catástrofes iminentes ${ }^{98}$. A encenação, tal como a alegoria criada por Liérmontov, espelhava o turbilhão fervilhante de uma época e sua inevitabilidade, como o destino. As alegorias da mascarada tornando-se "alegorias verídicas de uma sociedade que dançava sobre a voragem". 99

A jornada de Mascarada não se encerra em sua espetacular montagem de 1917 e nos poucos comentários reservados as montagens posteriores, Meterhold revisou a peça detalhadamente em pelo menos duas ocasiões e escreveu cadernos inteiros com anotações sobre os ensaios que guardam uma enorme gama de comentários, exemplos de atuação e, principalmente, as palavras que cunharam todo um novo teatro que estava nascendo. A tradução e análise de todo este material tão rico segue como um desafio complementar a esta breve introdução de Mascarada, uma

\footnotetext{
${ }^{97}$ Golstein, Vladimir. Liérmontov's Narratives of Heroism, Northern University Press, 1998, p. 70.

98 Ripelino, Angelo Maria. O truque e a Alma, Perspectiva, 1996, p. 198.

${ }^{99}$ Ripelino, Angelo Maria. O truque e a Alma, Perspectiva, 1996, p. 198.
} 
obra ainda pouco conhecida e estudada mas que, por sua grandiosidade tanto literária quanto estética, merece um lugar de honra na história do drama e da literatura. 


\section{BIBLIOGRAFIA:}

ADORNO, Theodor - Notas de Literatura I. São Paulo: Editora 34, 2003

ALEXANDRE, M. (org). Romantiques allemands. Paris: Pléiade, 1963

ALLEN, Elisabeth Cheresh - A Fallen Idol is Still a God: Liérmontov and the Quandraries of Social Transition, Stanford University Press, 2006

ARGAN, Giulio Cario - Historia da Arte Italiana, 3 vol. São Paulo, Cosack \& Naify, 2002

ARISTÓTELES. Poética. Lisboa: Imprensa Nacional/Casa da Moeda, 1992

ARNALDO, Javier (org.).Fragmentos para uma teoría romántica del arte (Novalis, Schiller, Kleist, Hölderlin...) Madrid, Tecnos, 1987

AUERBACH, Erich - Mimesis. São Paulo: Perspectiva, 1971

BAKHTIN, M. Problemas da poética de Dostoiévski. Rio de Janeiro: Forense Universitária, 1997

Questões de Literatura e de Estética. São Paulo:

UNESP/HUCITEC, 1988

BAKHTIN, Mikhail (Volochínov). Marxismo e filosofia da linguagem. Trad. Michel Lahud e Yara Frateschi Vieira. São Paulo: Hucitec, 1981

BAUDELAIRE, Charles. Poesia e Prosa. Rio de Janeiro, Nova Aguilar, 2002 HOFFMANN, E. T. A. Contos fantásticos. São Paulo: Imago.

BERLIN, Isaiah - Pensadores Russos, São Paulo, Companhia das Letras, 1988

BERNARDINI, Aurora - "O século 19 na Rússia e os ícones da prosa mundial". In: Revista Cult, ano 12, № 132. São Paulo, Ed. Bregantini, fev. 2009

BENJAMIN, Walter. Ensaios sobre literatura e história da cultura. Obras escolhidas. Volume 1. Trad. Sergio Paulo Rouanet. São Paulo: Brasiliense, 1986 
BENJAMIN, Walter. Illuminations. Schoken Books, New York, 1969

BENJAMIN, Walter. Magia e técnica, arte e política - Ensaios sobre literatura e história da cultura. Obras escolhidas. Volume 1. Trad. Sergio Paulo Rouanet. São Paulo: Brasiliense, 1986

BENTLEY, Eric. O Dramaturgo como Pensador. Rio de Janeiro: Civilização Brasileira, 1991

BOSI, Alfredo (org.) - O Conto Brasileiro Contemporâneo. São Paulo: Cultrix, Editora da universidade de São Paulo, 1975

The Cambridge History of Russian Literature. Cambridge: Cambridge University Press, 1992

CANDIDO, Antonio - "A literatura e a formação do homem" in Remate de Males. Campinas, Revista do Departamento de Teoria Literária. Unicamp. 1999

CANDIDO, Antonio et alli. - A Personagem de Ficção. São Paulo: Perspectiva, 1984

CARLSON, Marvin. Teorias do Teatro. Estudo histórico-crítico dos gregos à atualidade. São Paulo, Editora da UNESP, 1998

CORTÁZAR, Julio - Valise de Cronópio. São Paulo: Perspectiva, 1974

DERRIDA, Jacques - A Escritura e a Diferença. São Paulo, Perspectiva, 1971

ESSLIN, Martin. The Field of Drama. London: Methuen Drama, 1988 . Uma anatomia do drama. Rio de Janeiro: Zahar, 1978

ESTÉTICA TEATRAL. TEXTOS DE PLATÃo A BRECHT. ED. M. BORIE. Porto: Fundação Gulbenkian, 1996

GASSNER, John. Mestres do Teatro I. São Paulo: Perspectiva, 1974. . Mestres do Teatro II. São Paulo: Perspectiva, 1980

GOLSTEIN, Vladimir - Liérmontov's Narratives of Heroism, Northern University Press, 1998

GOTTLIB, Nadia - Teoria do Conto. São Paulo: Ática, 1985 
HEGEL. Estética: Poesia. Trad. Álvaro Ribeiro. Lisboa: Guimarães Editores, 1964

HUTCHEON, Linda - Uma Teoria da Paródia. Lisboa, Edições 70

KOCHAN, Lionel - A formação da Rússia Moderna. Lisboa, Editora Ulisseia, 1962

LEACH, Robert - Vsevolod Meyerhold, Cambridge University Press, 1989

LUKÁCS, Georg - A teoria do Romance. São Paulo: 34 Letras, 2000

LUKÁCS, Georg - Ensaios sobre Literatura. Rio de Janeiro: Civilização Brasileira, 1968

MACHADO, Roberto. O nascimento do Trágico de Schiller a Nietzsche. Rio de Janeiro: Jorge Zahar Ed., 2006

NUNES, Benedito - O Tempo na Narrativa. São Paulo: Ática, 1989

PAVIS, Patrice. Dicionário de teatro (Tradução para a língua portuguesa sob a direção de J. Guinsburg e Maria Lúcia Pereira). São Paulo: Perspectiva, 1999

PICON-VALLIN, B. A arte de teatro. Rio de Janeiro: TPG: Letra e Imagem, 2006 . A cena em ensaios. São Paulo: Perspectiva, 2008

POMORSKA, Krystyna - Formalismo e futurismo. São Paulo, Perspectiva, 1972

RIPELINO, Angelo Maria - O Truque e a Alma, Perspectiva, 1996

RIPELINO, Angelo Maria - letteratura comme Itinerario nel Maravilloso, Barral Editores, 1970

ROSENFELD, A. O Teatro épico. São Paulo: Perspectiva, 2006

RUDNITSKY, Konstantin - Russian and Soviet Thatre, tradition and avant-garde, Thames and Hudson, 1989

SCHNAIDERMAN, B. Dostoiévski: Prosa Poesia. São Paulo: Perspectiva, 1982

SCHLEGEL, F. O dialeto dos fragmentos. São Paulo: lluminuras, 1996 
TINIANOV, luri O Problema da linguagem poética: o ritmo como elemento construtivo do verso e $O$ problema da linguagem poética II: o sentido da palavra poética. Rio de Janeiro, Tempo Brasileiro, 1975

TODOROV, Tzvetan - Estruturalismo e Poética - 4ª ed. São Paulo, Cultrix, 1973

TODOROV, Tzvetan - "A Herança Metodológica do Formalismo" $2^{\mathrm{a}}$ Ed. In:, As Estruturas Narrativas São Paulo, Perspectiva, 1970

TOLEDO, Dionísio de Oliveira. Teoria da Literatura - formalistas russos. $1^{\mathrm{a}}$ ed. $2^{\mathrm{a}}$ reimpr. Trad. Ana Mariza Ribeiro Filipouski; Maria Aparecida Pereira; Regina L. Zilberman; Antônio Carlos Hohlfeldt. Porto Alegre: Globo, 1973

TOLSTOI, Leão - Os dezembristas, in Obra Completa, Rio de Janeiro: Editora Aguilar, vol. II, 1961

TYNJANOV, Jurij - Avanguardia e Tradizione. Bari, Dédalo Libri, 1968

WATT, Ian - A Ascensão do Romance. São Paulo: Companhia das Letras, 1990

WÕLFFLIN, Heinrich - Conceitos Fundamentais da Historia da Arte, trad. J. Azenha Jr., São Paulo, Martins Fontes, 1984

ZONDI, Peter. Teoria do drama Moderno 1880-1950. Trad. Luiz Sério Repa. São Paulo: Cosac \& Naify, 2001 . Teoria do drama burguês. Trad. de Luiz Sério Repa. São Paulo: Cosac \& Naify, 2004 . Ensaio sobre o trágico. Trad. de Pedro Süssekind. Rio de Janeiro: Jorge Zahar, 2004 


\section{Anexo:}

\section{Imagens}

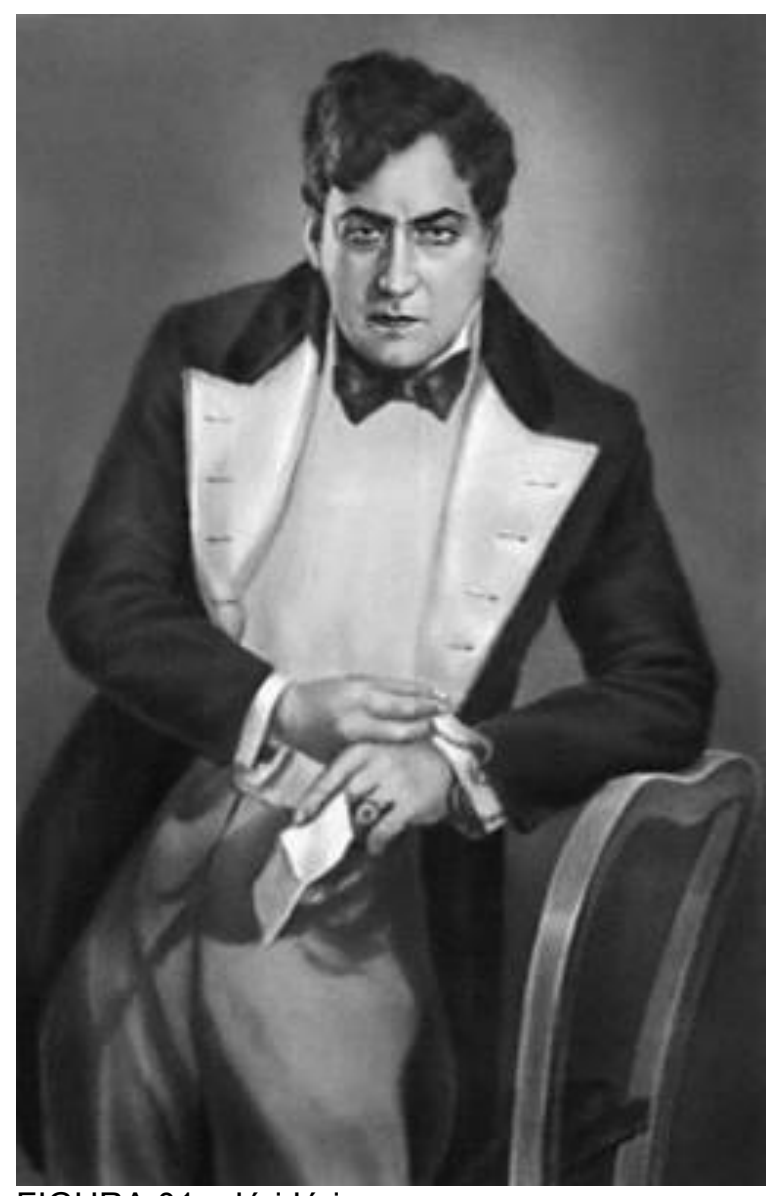

FIGURA 01 - lúri lúriev

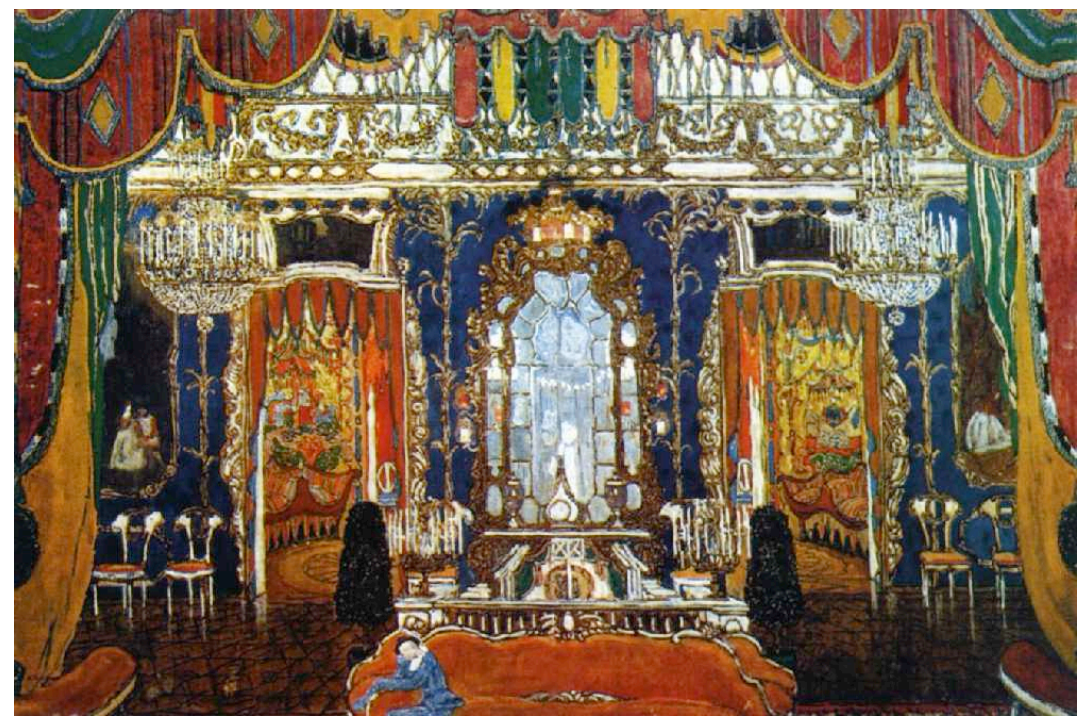

FIGURA 02 - Pierrô Azul no canapé adamascado ao fundo do palco 


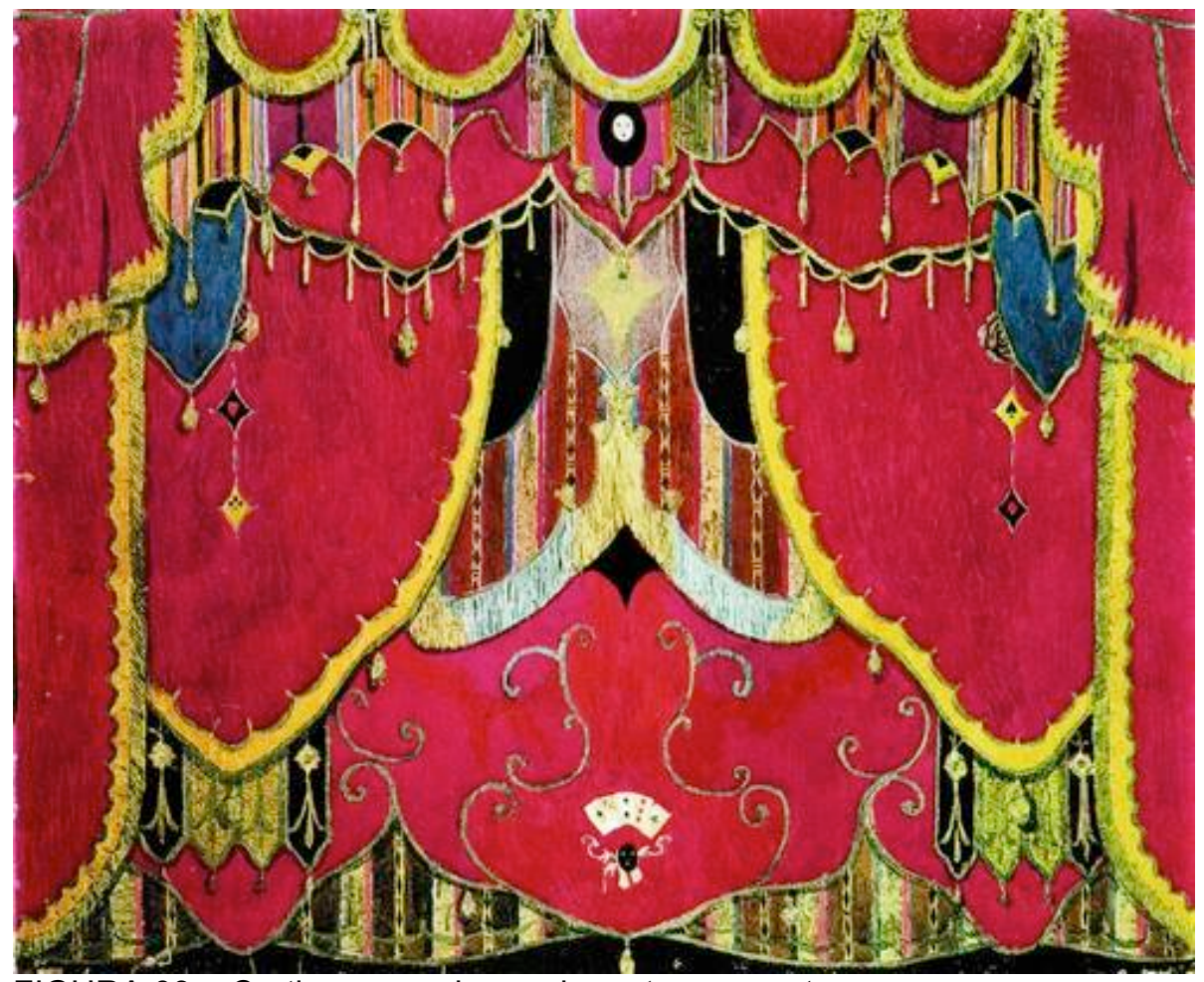

FIGURA 03 - Cortina com o leque de cartas ao centro

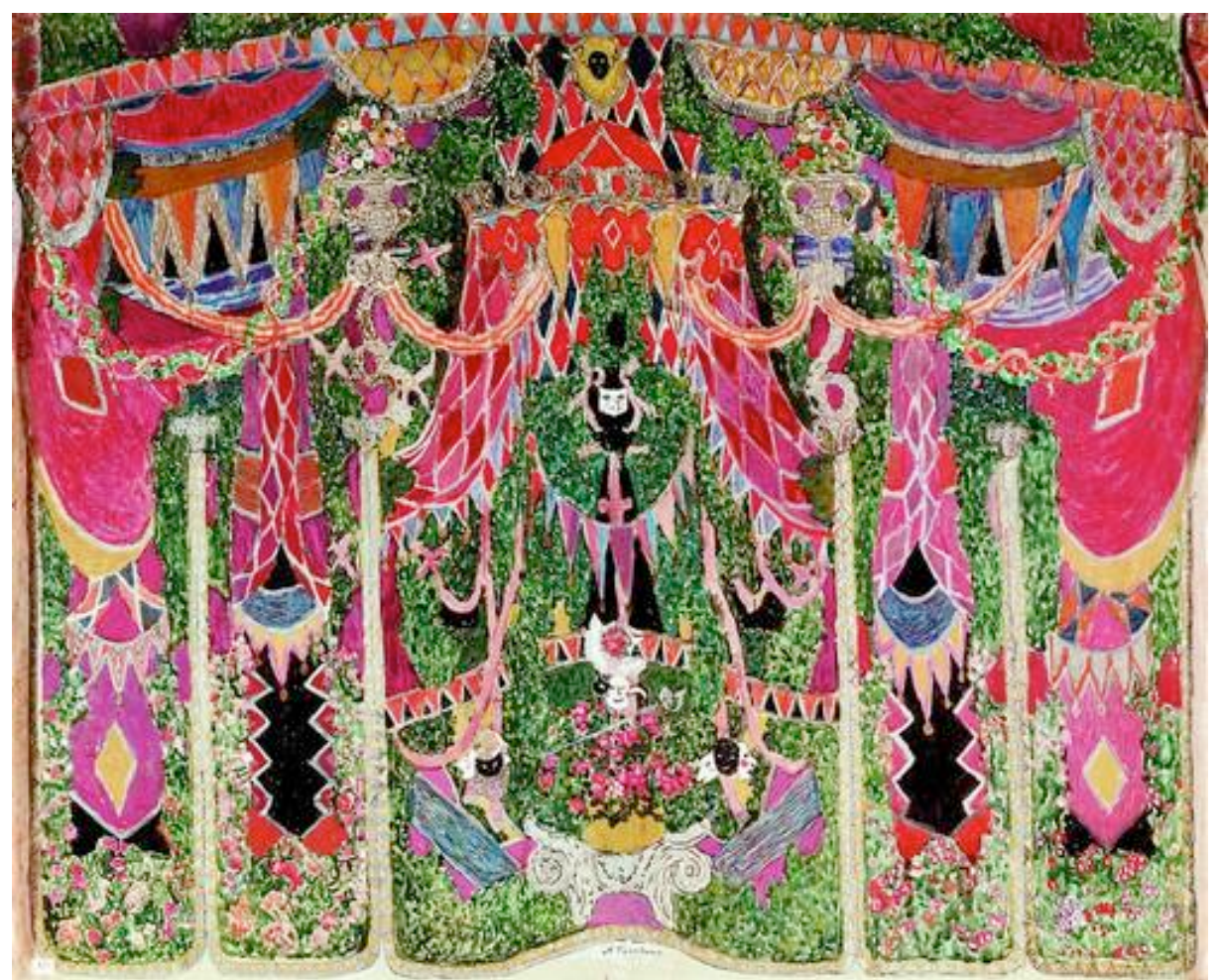

FIGURA 04 - Cortina da mascarada 


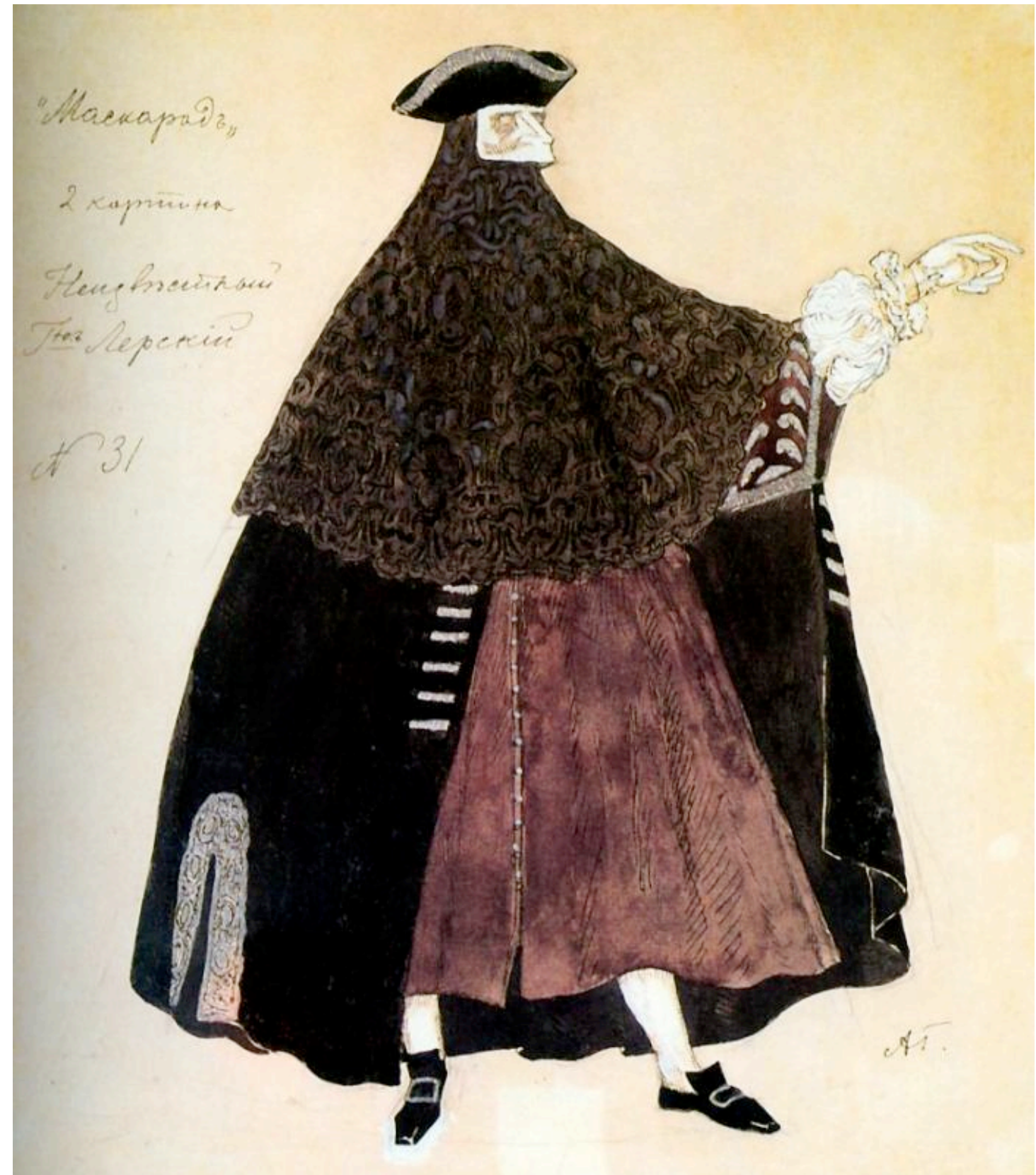

FIGURA 05 - Esboço de Golovin para o Desconhecino 


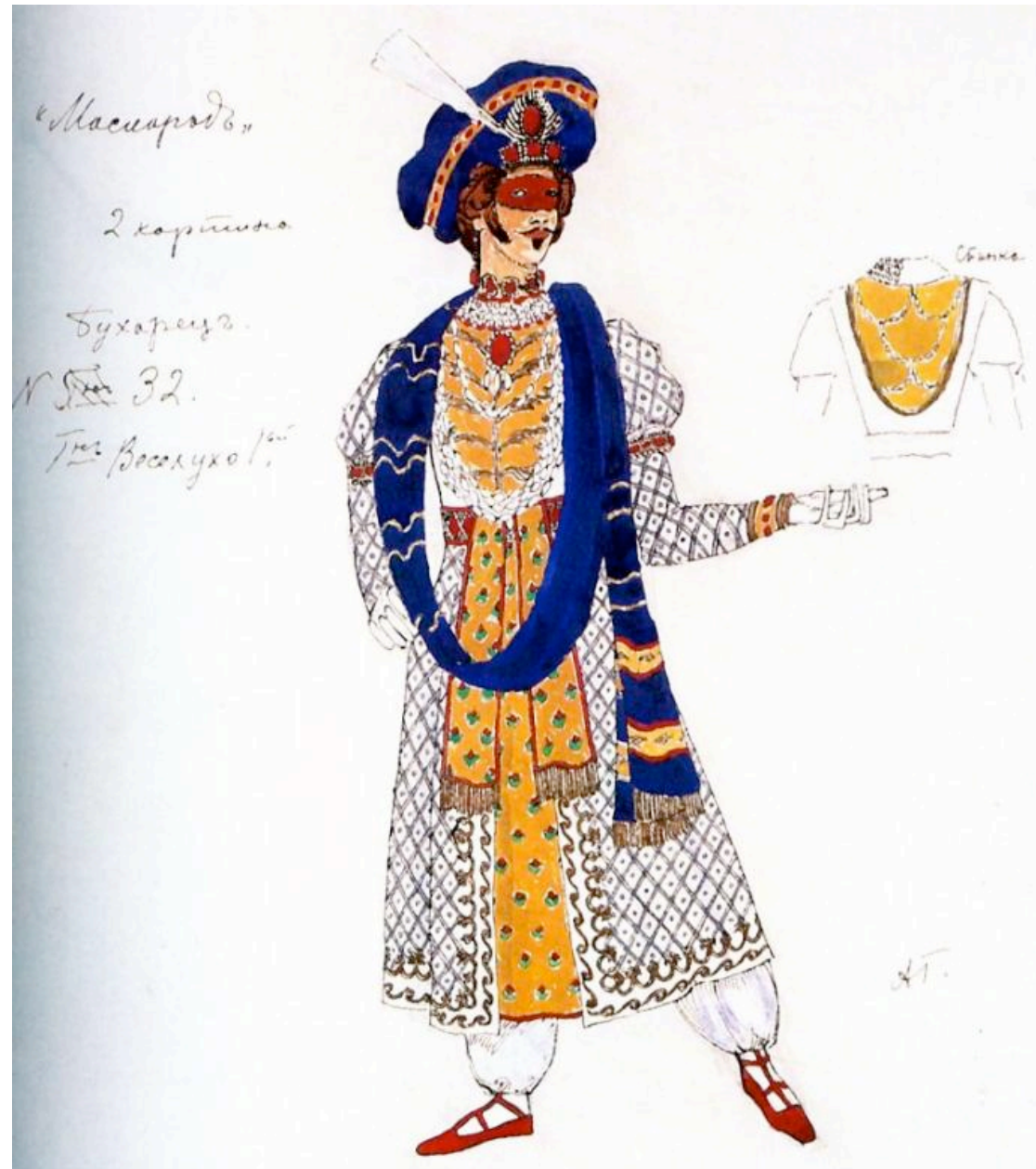

FIGURA 06 - Esboço de Golovin para fantasia da mascarada
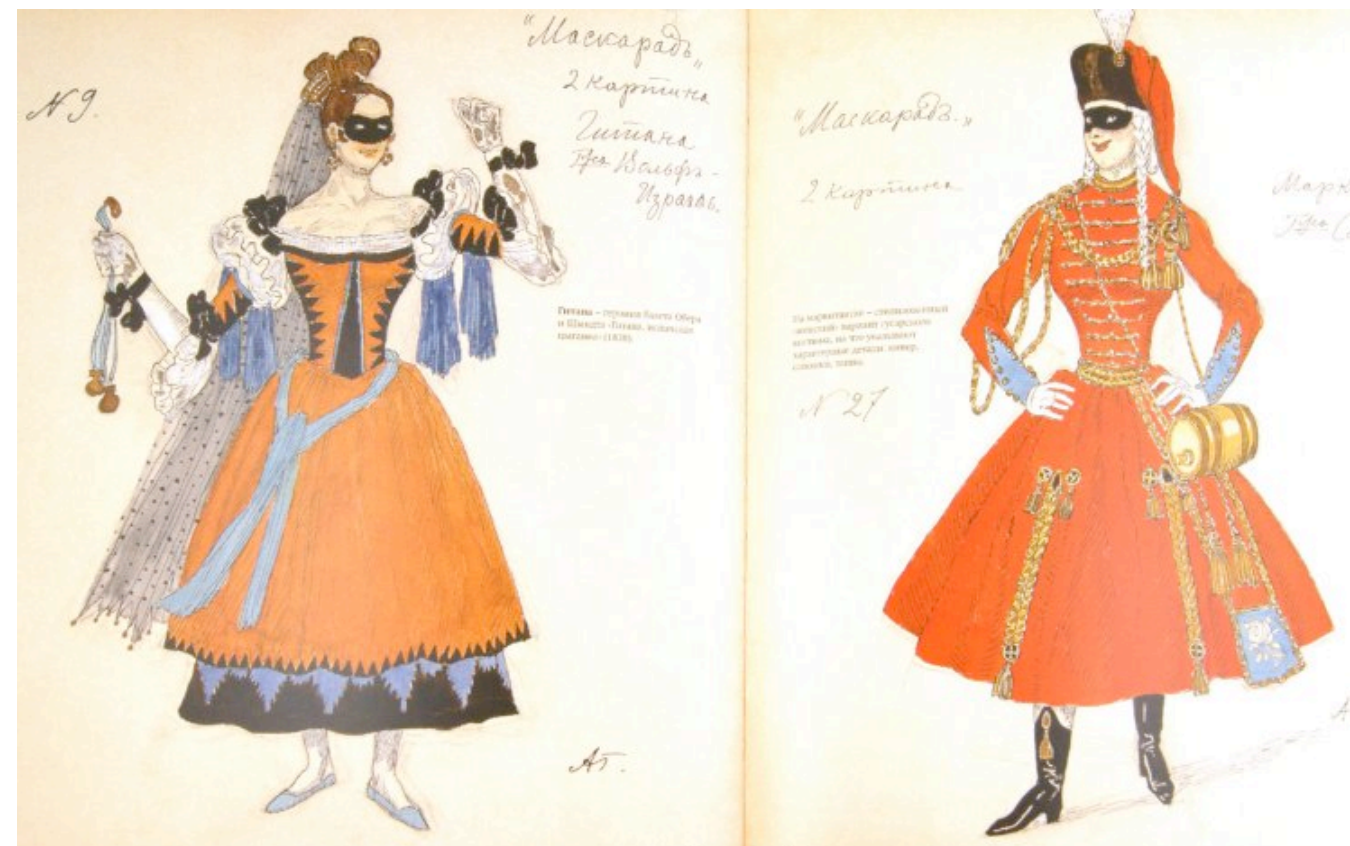

FIGURA 07 - Esboços de Golovin para fantasias da mascarada 


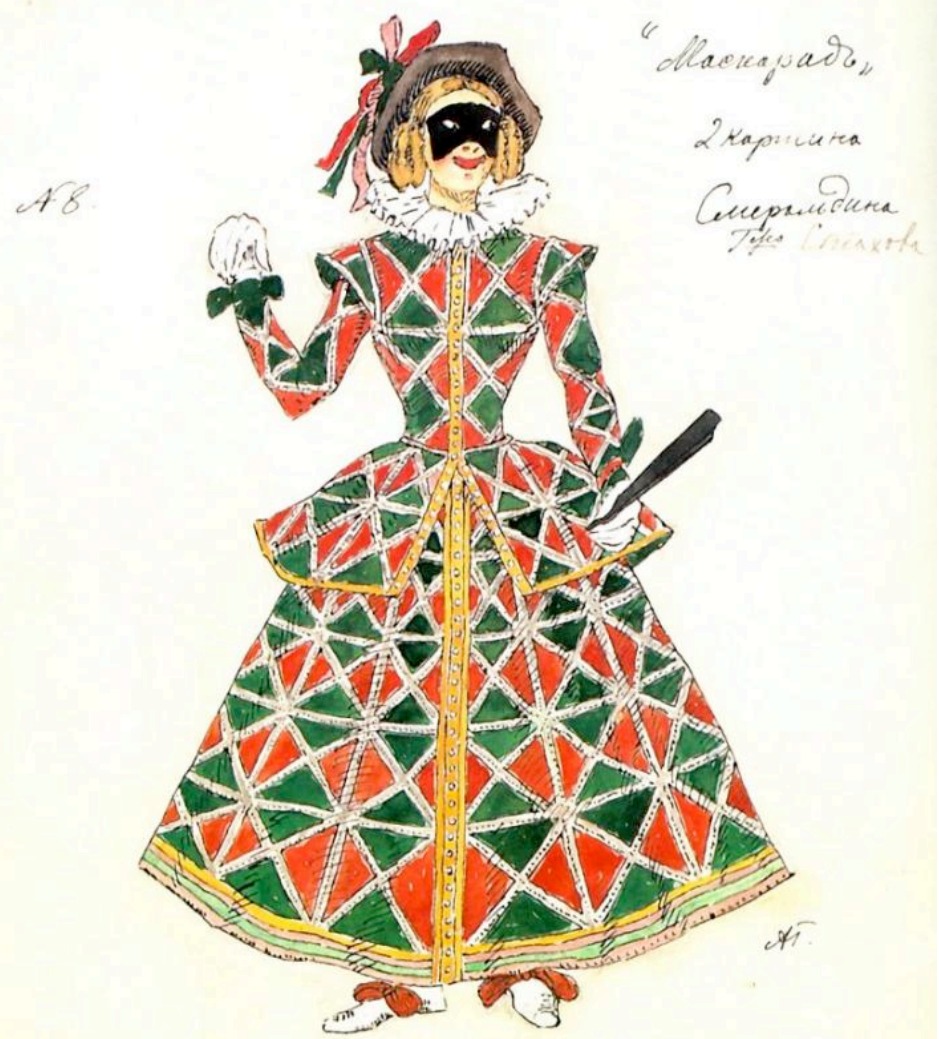

FIGURA 08 - Esboço de Golovin para fantasia da mascarada

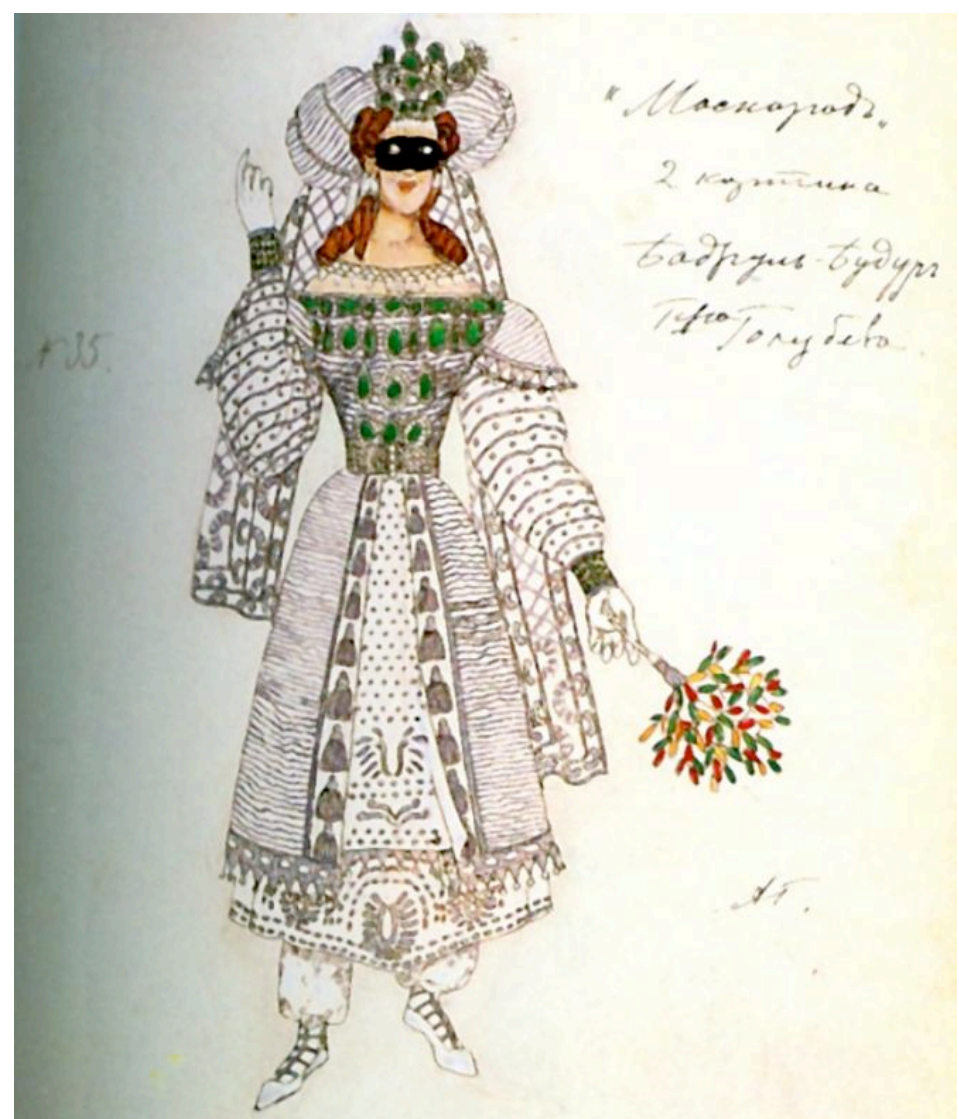

FIGURA 09 - Esboço de Golovin para fantasia da mascarada 


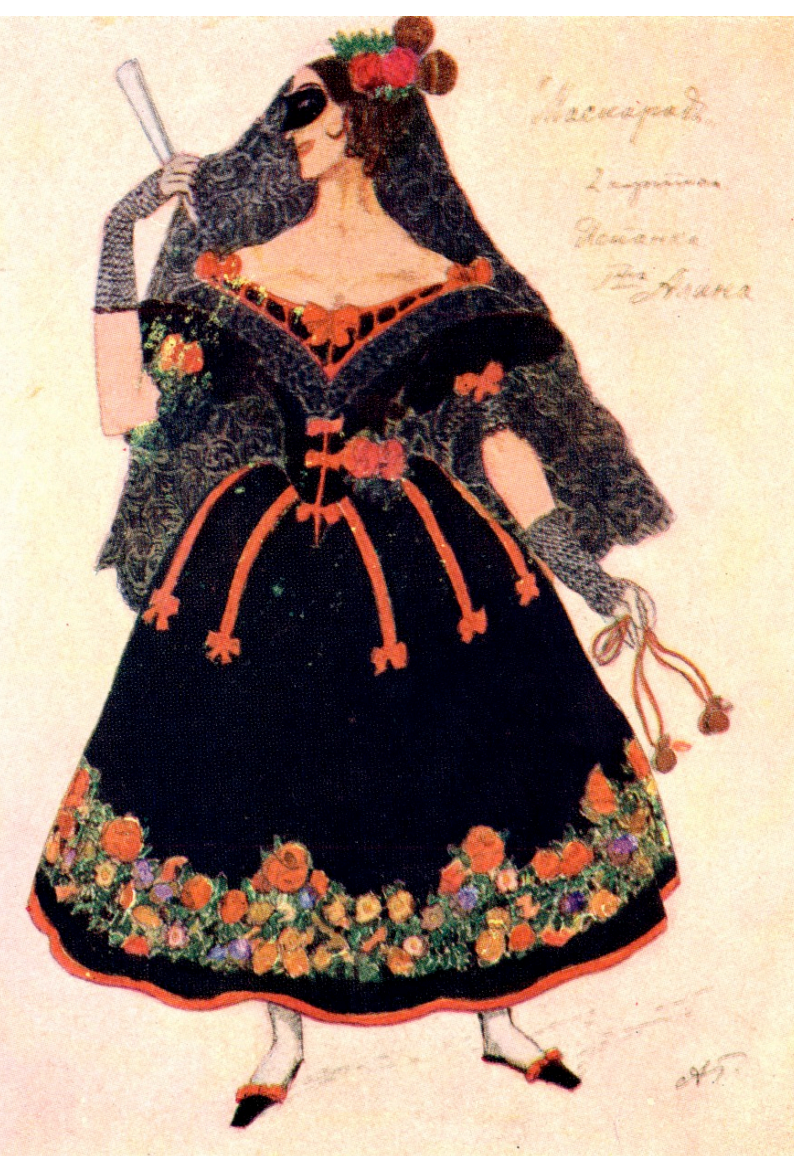

FIGURA 10 - Esboço de Golovin para fantasia da mascarada

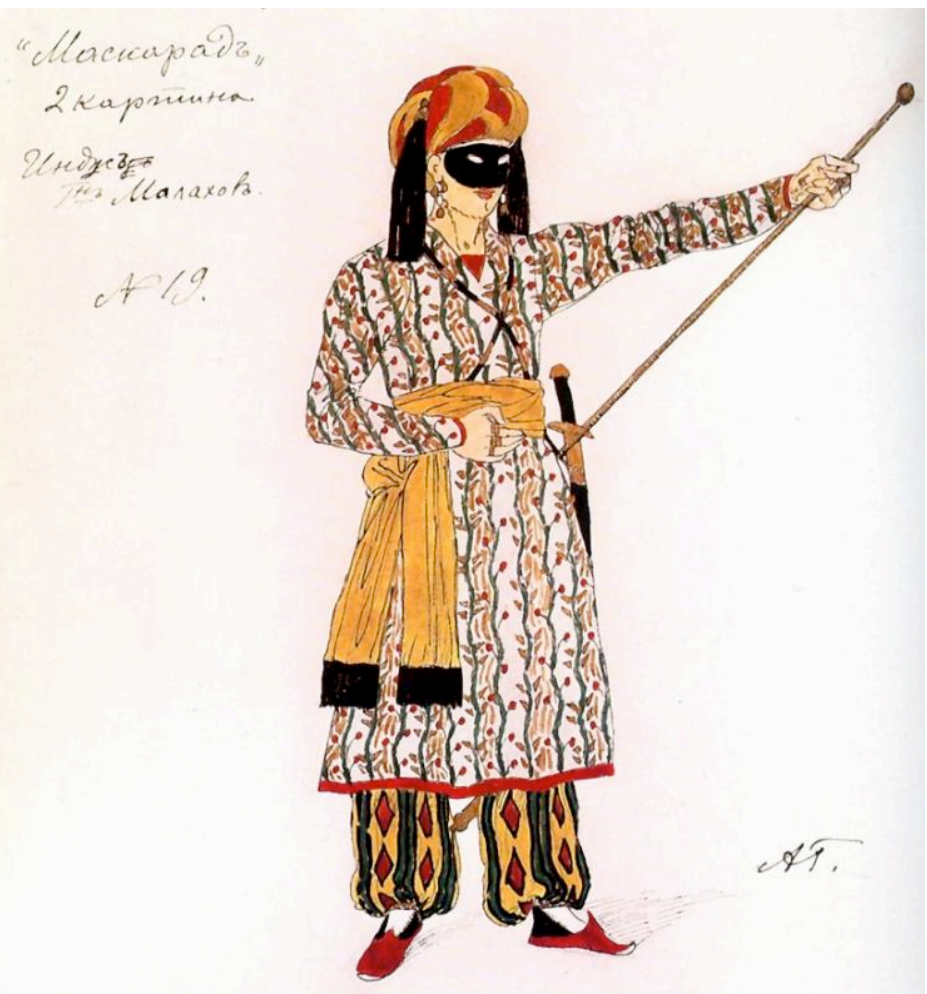

FIGURA 11 - Esboço de Golovin para fantasia da mascarada 


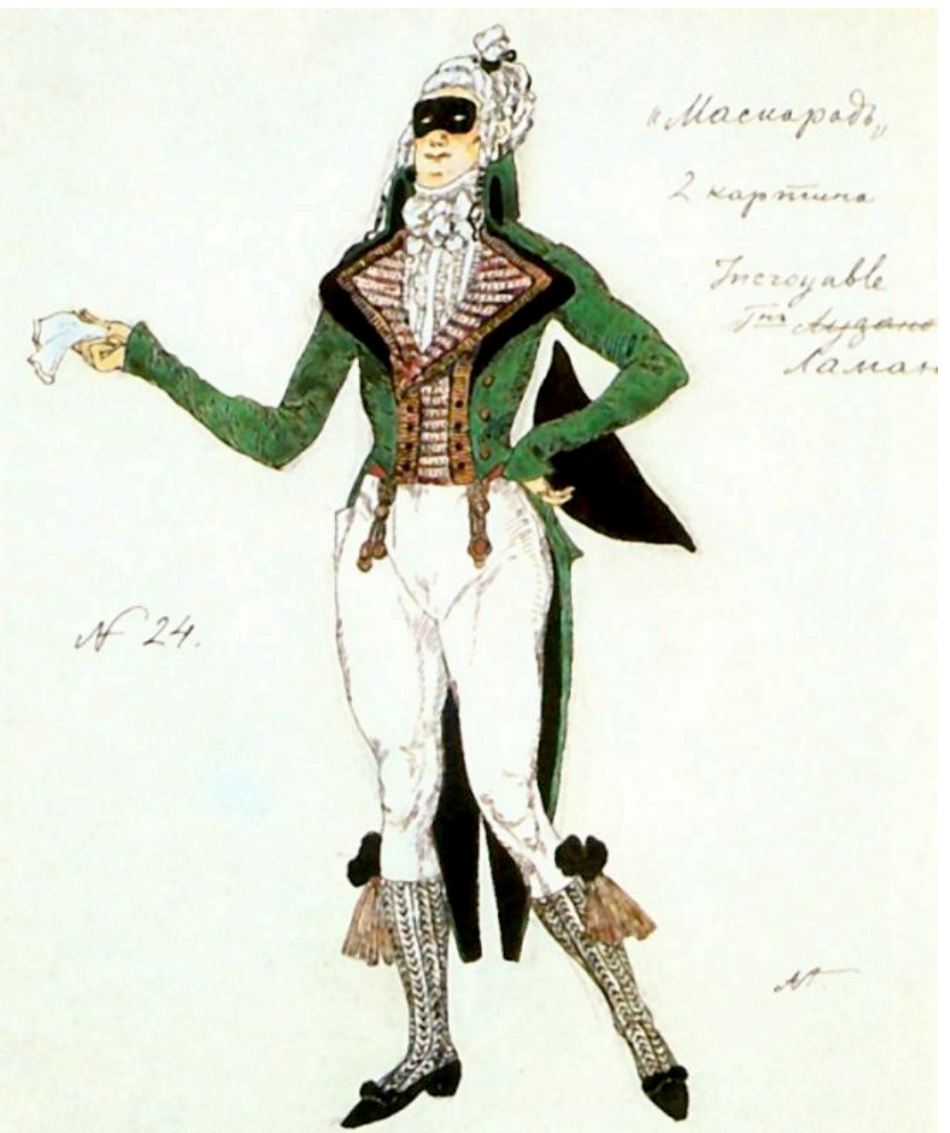

FIGURA 12 - Esboço de Golovin para fantasia da mascarada

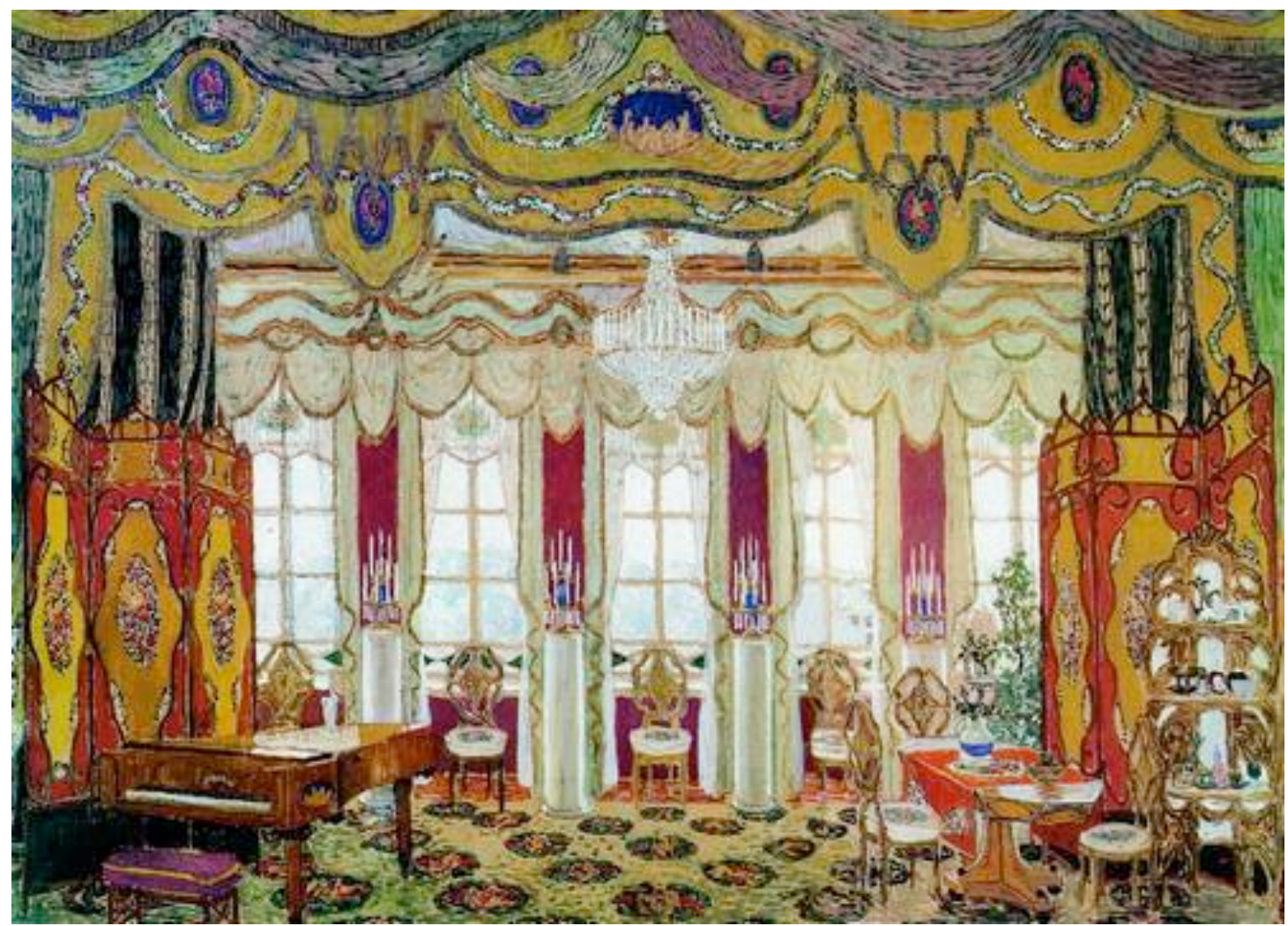

FIGURA 13 - Salão do baile em sociedade 


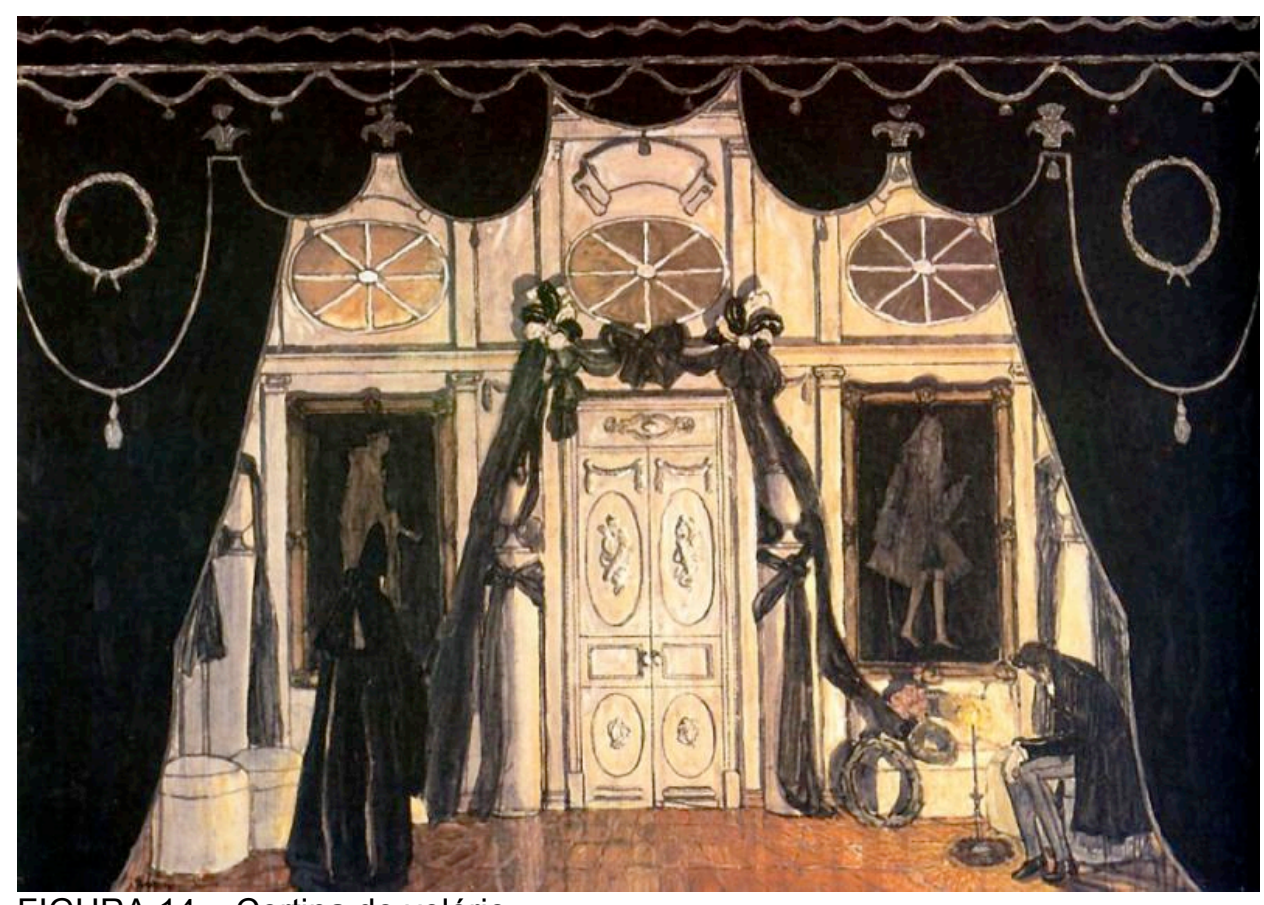

FIGURA 14 - Cortina do velório

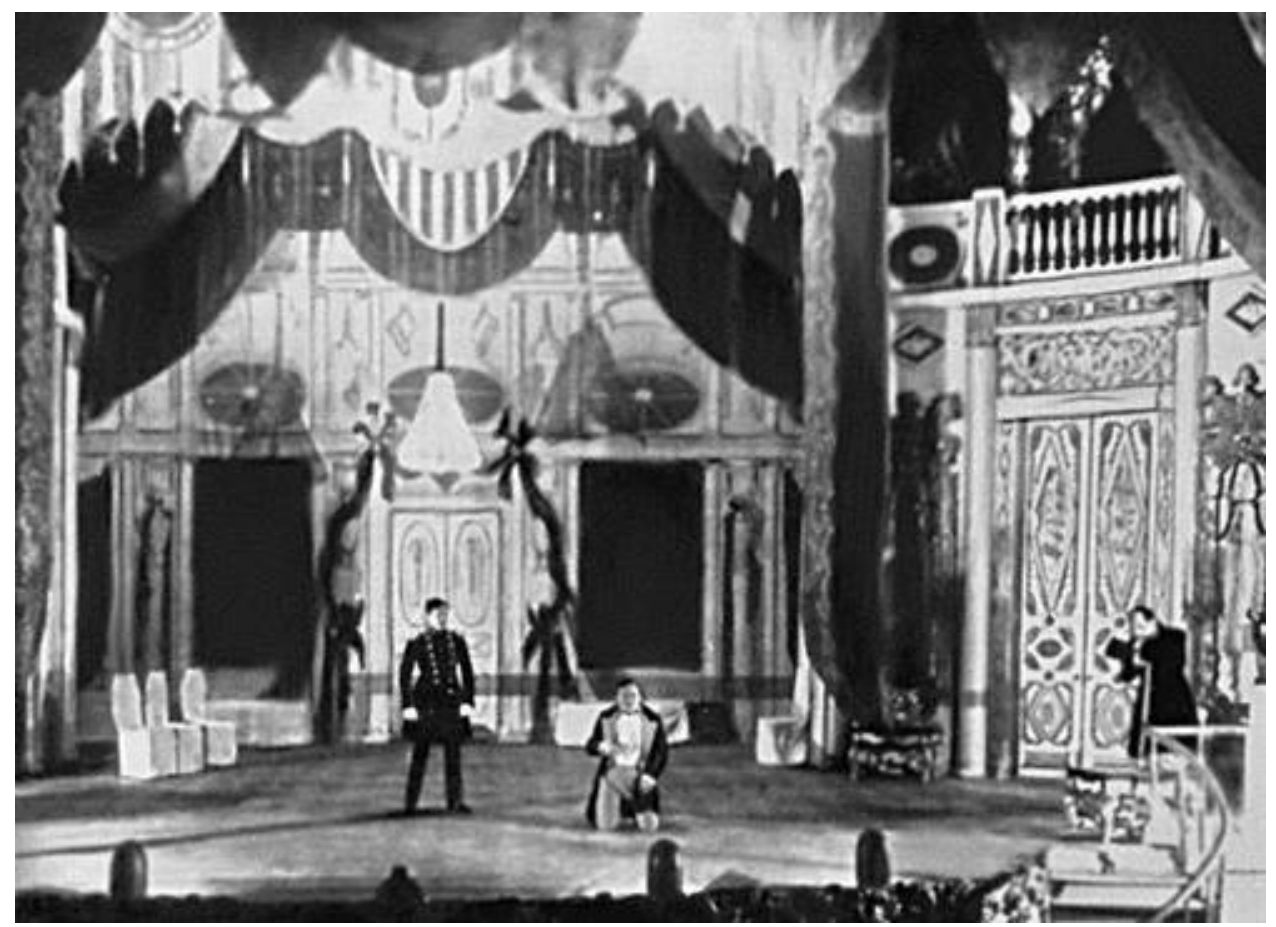

FIGURA 15 - Cena final de Mascarada 


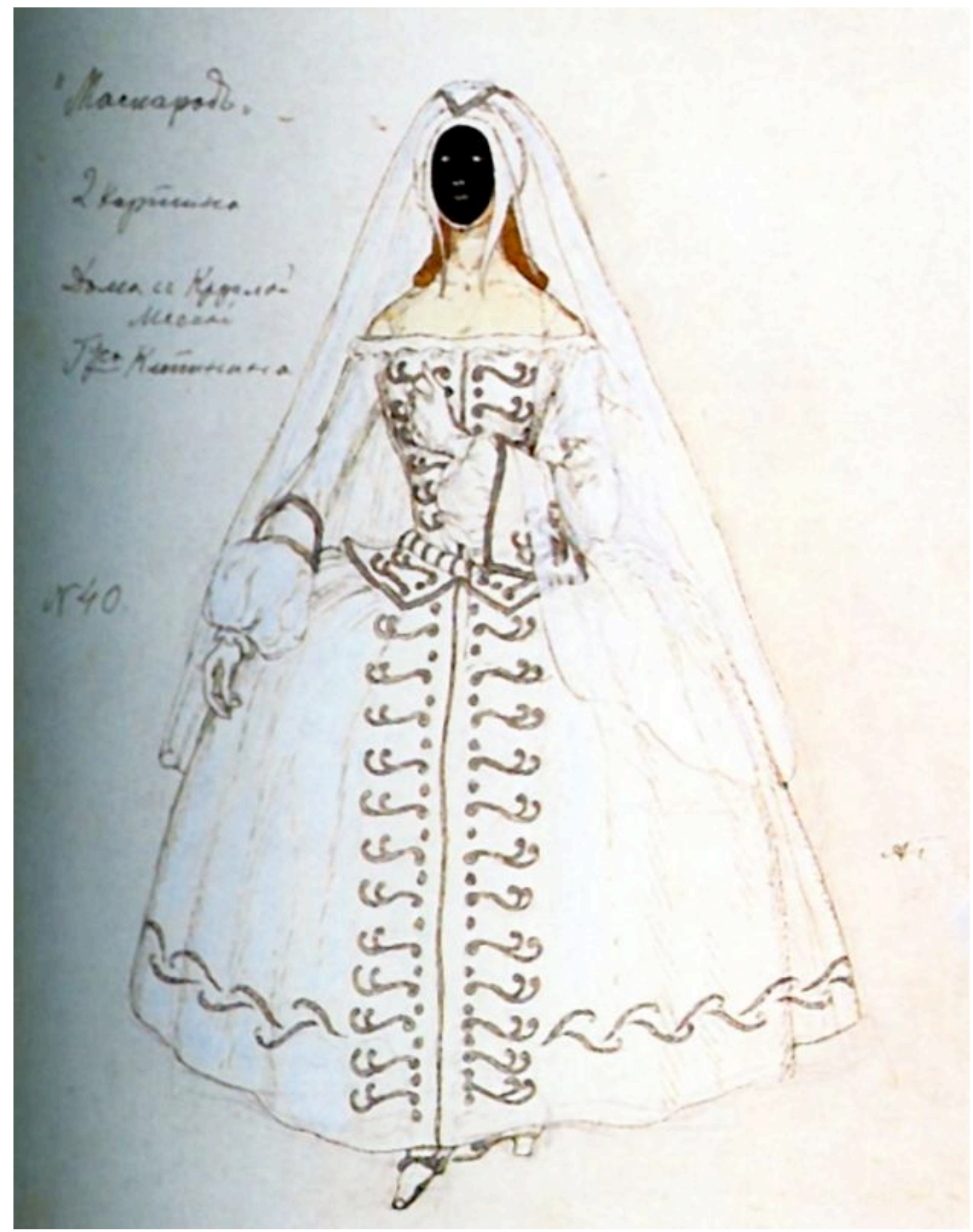

FIGURA 16 - Esboço de Golovin para o figurino da mascarada 


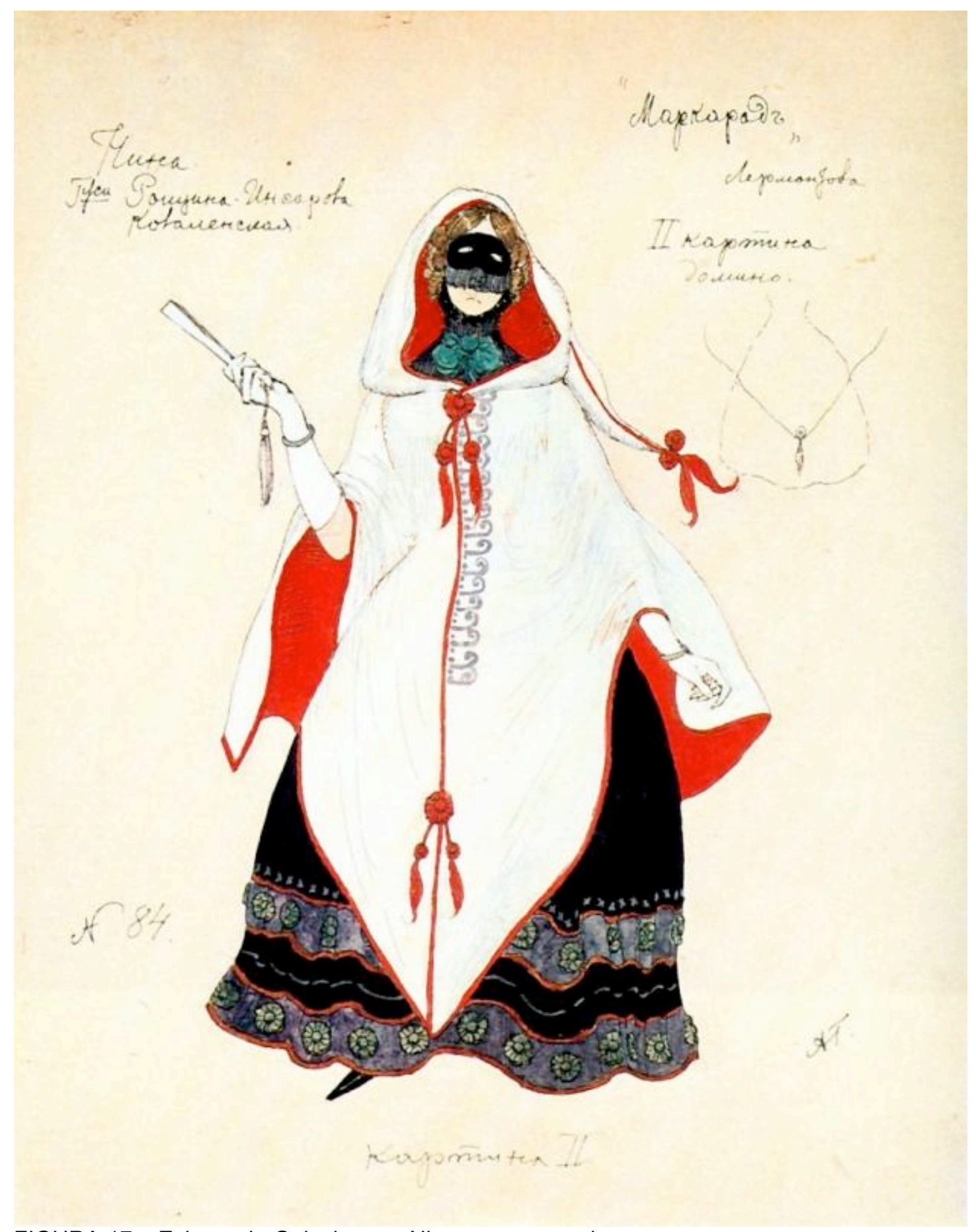

FIGURA 17 - Esboço de Golovin para Nina na mascarada 


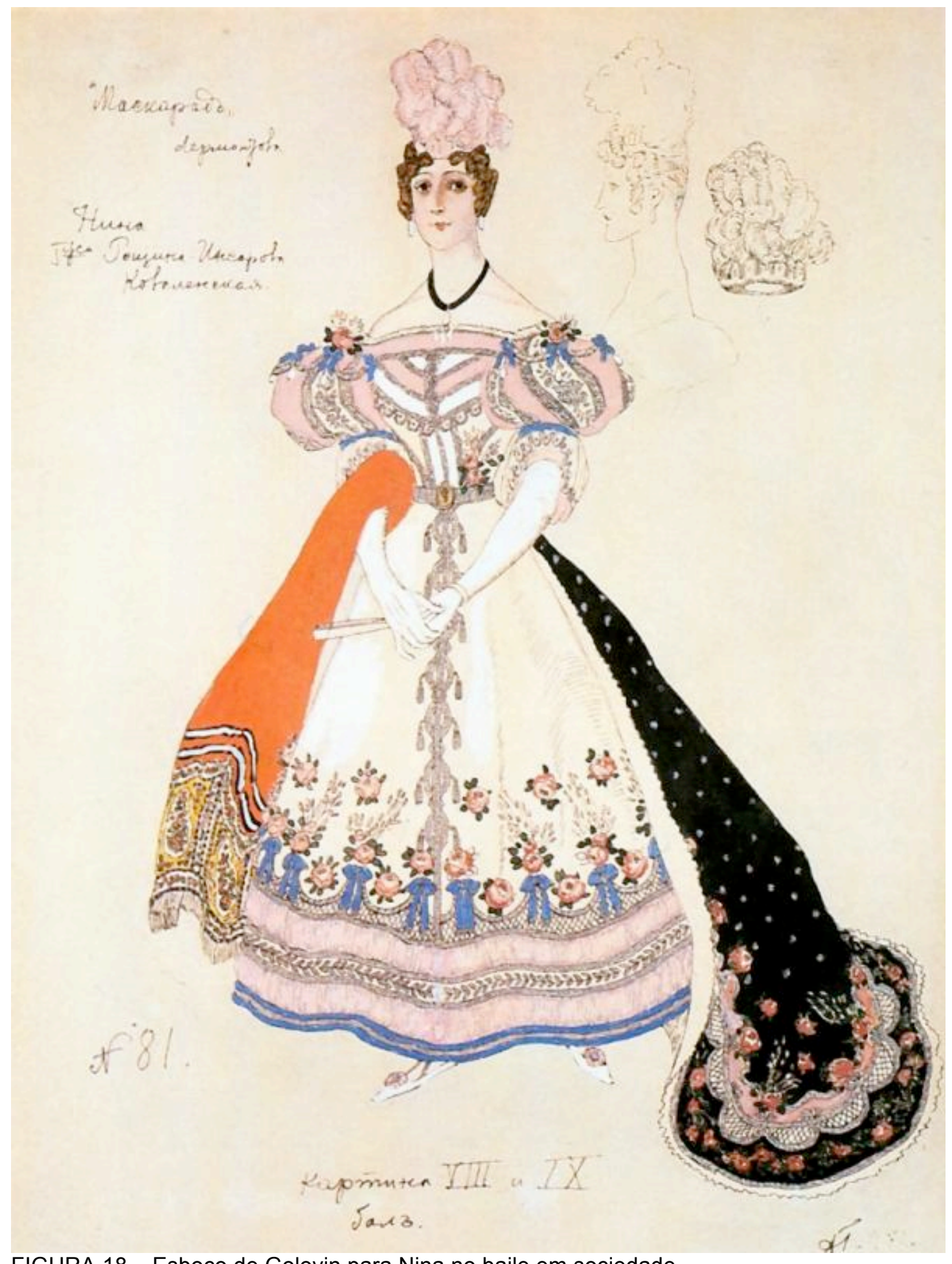

FIGURA 18 - Esboço de Golovin para Nina no baile em sociedade 


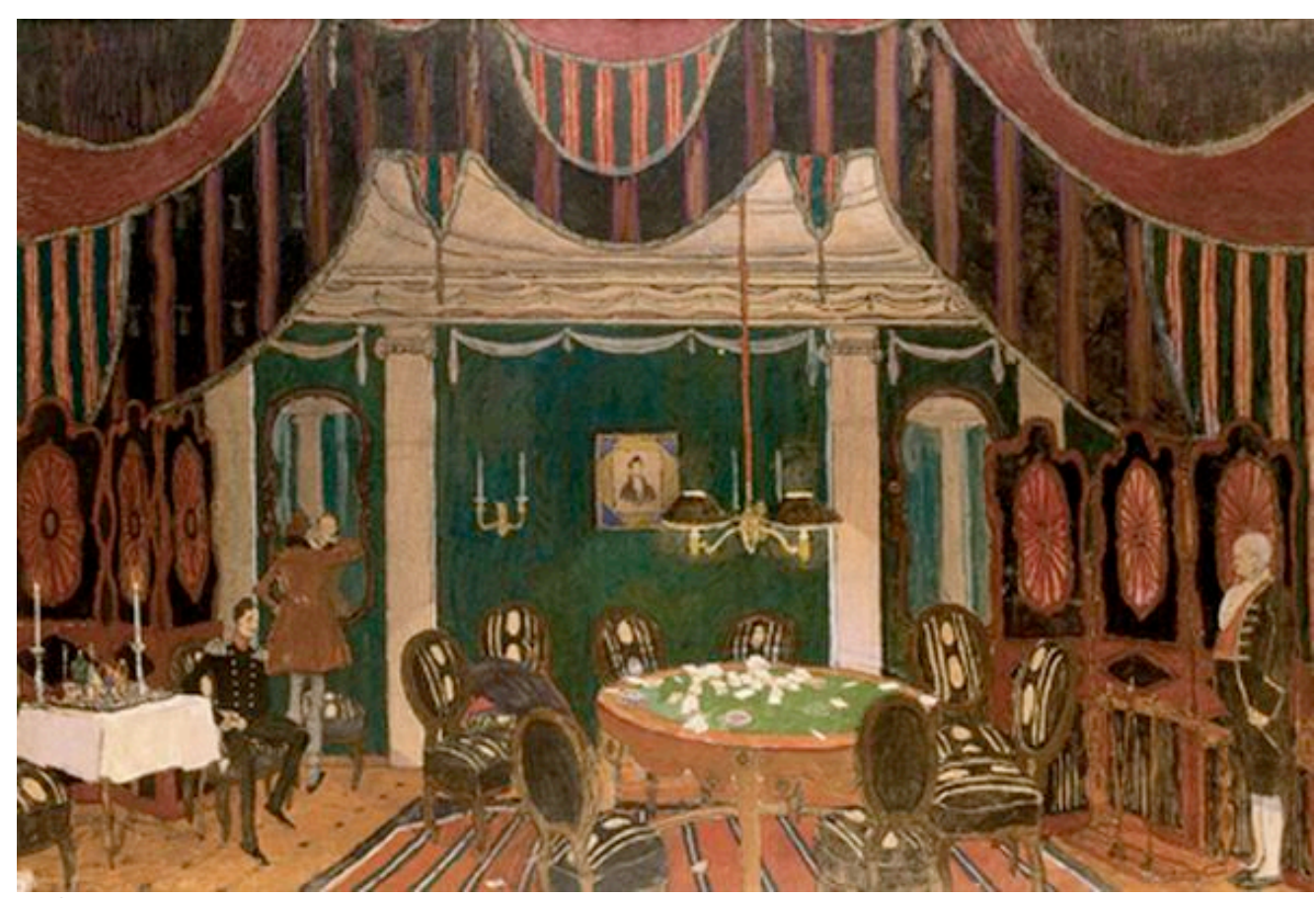

FIGURA 19 - Mesa de jogo da cena I

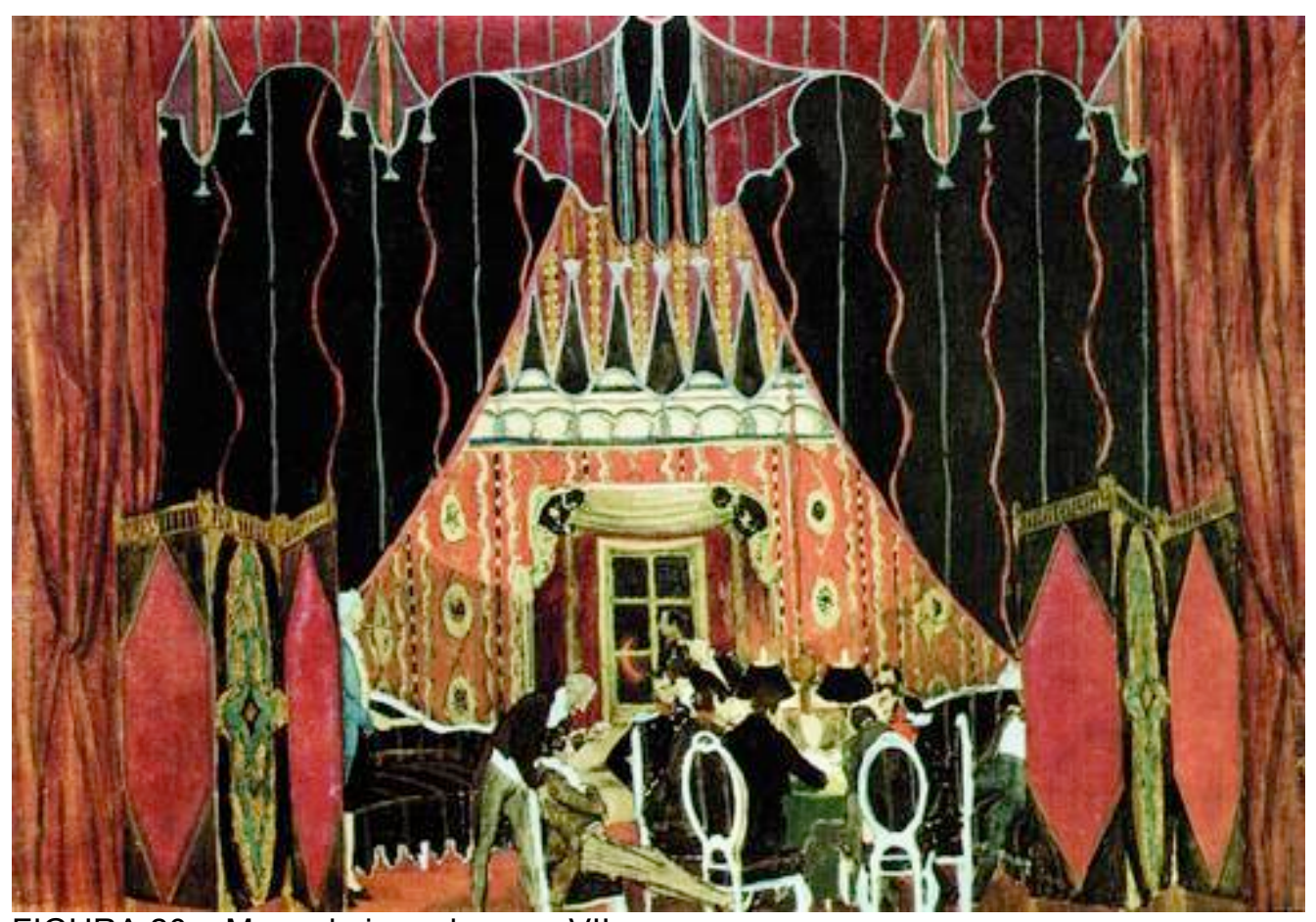

FIGURA 20 - Mesa de jogo da cena VII 


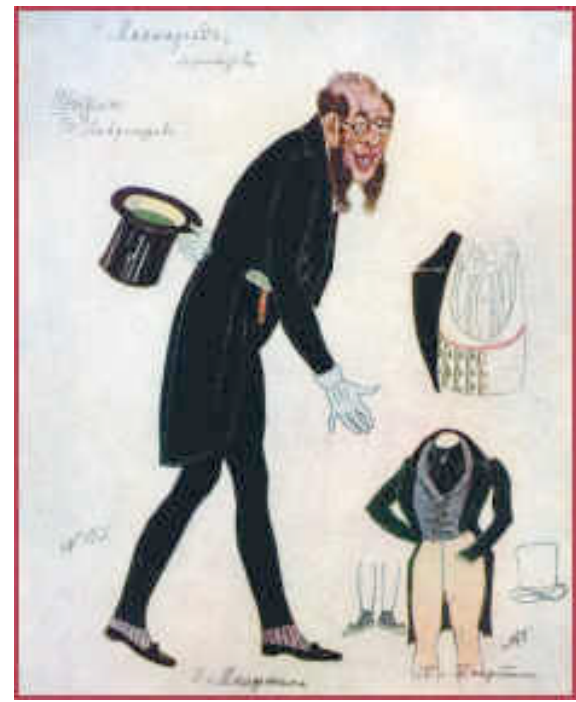

FIGURA 21 - Esboço de Golovin para Chprikh

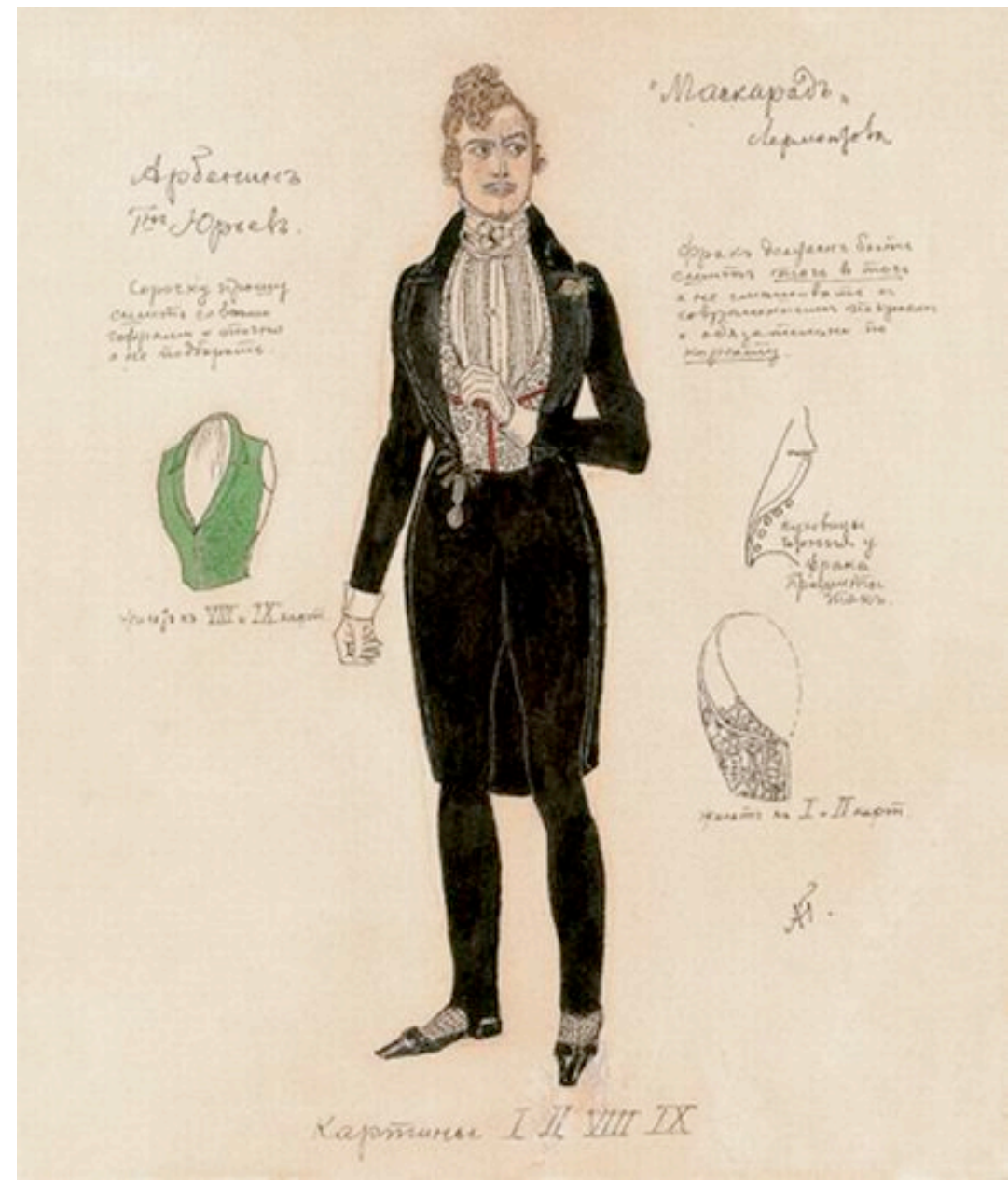

FIGURA 22 - Esboço de Golovin para Arbiénin 


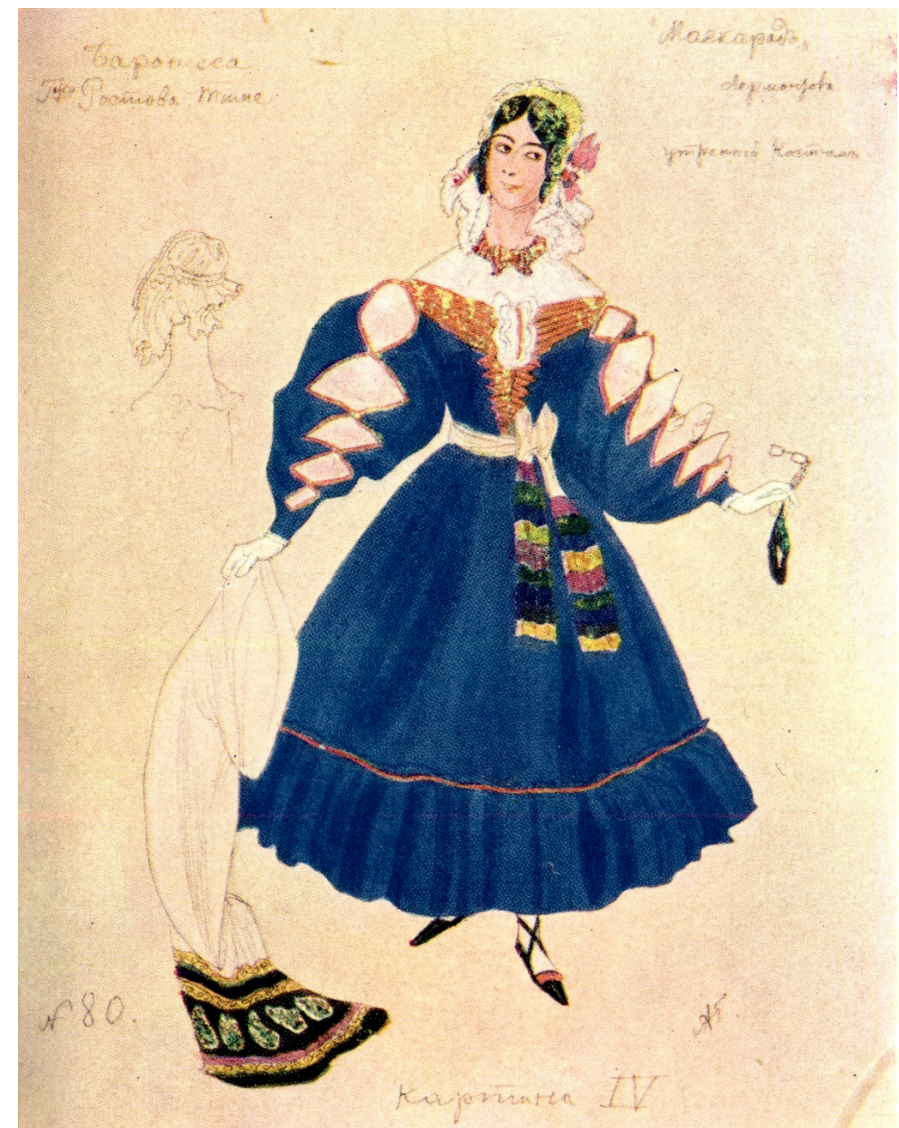

FIGURA 23 - Esboço de Golovin para a Baronesa

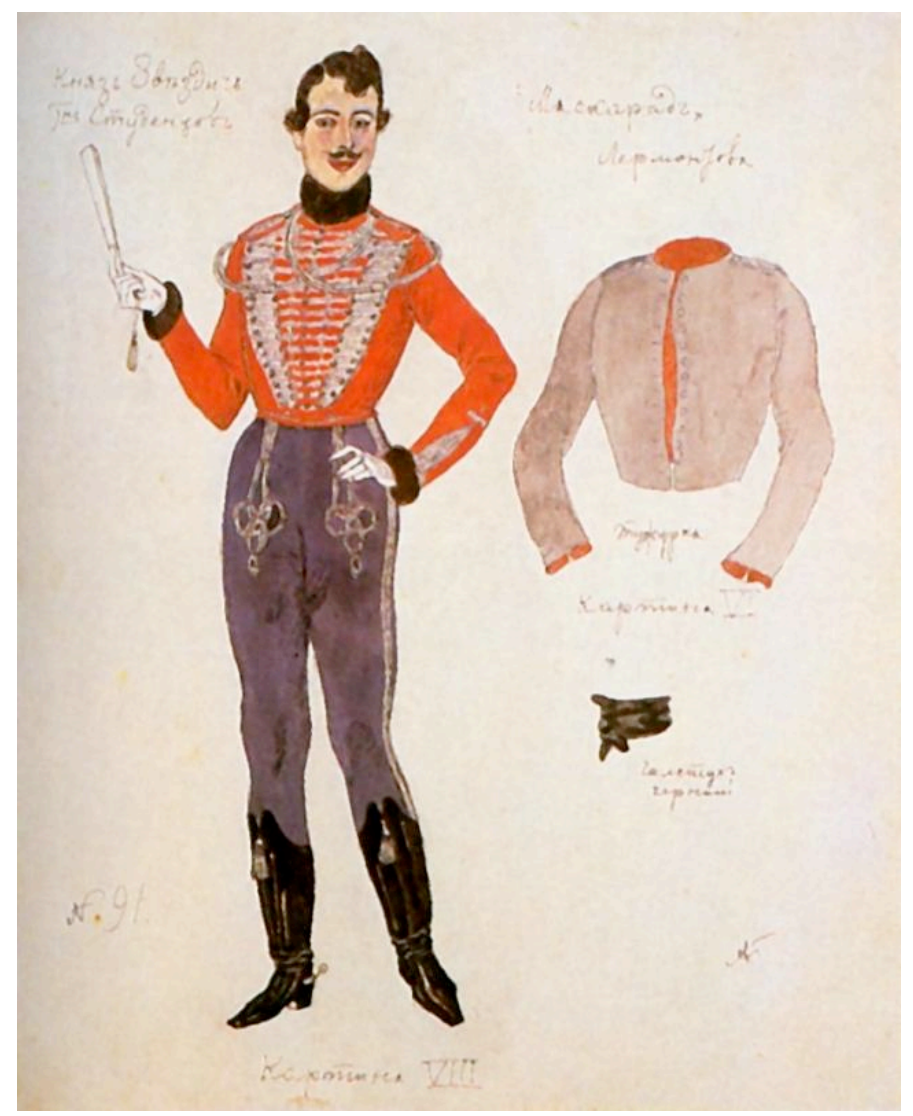

FIGURA 24 - Esboço de Golovin para o Príncipe 